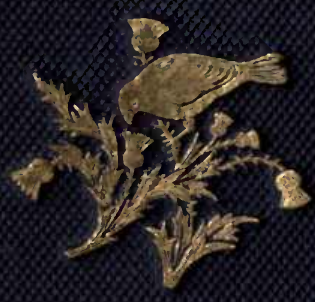




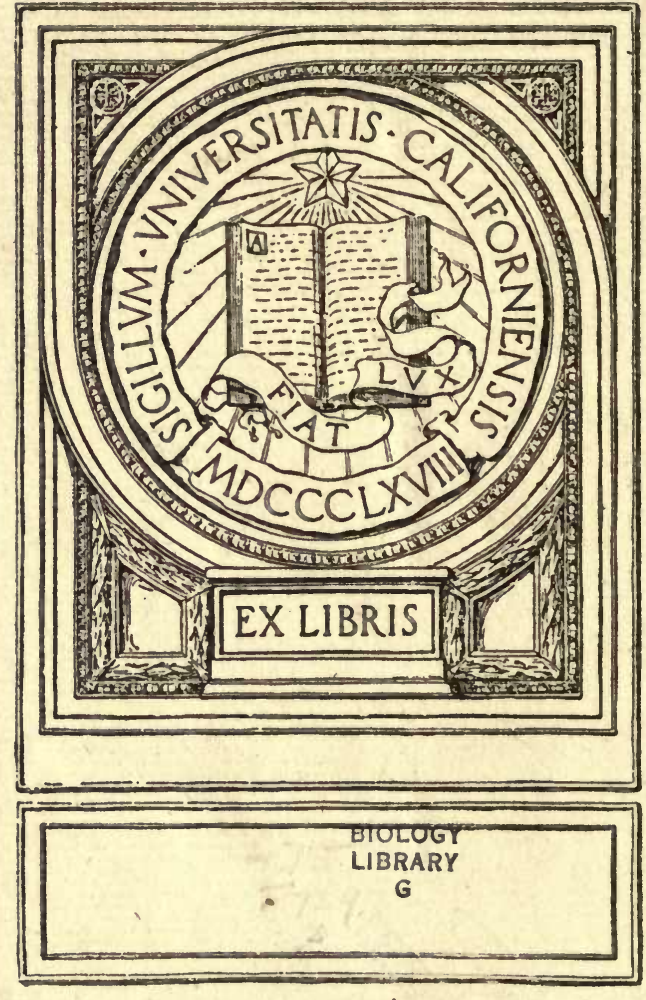








\title{
SUMMER STUDIES
}

\author{
oF \\ BIRDS AND BOOKS
}


2Ax 


\section{SUMMER STUDIES}

\section{OF \\ BIRDS AND BOOKS}

BY

W. WARDE FOWLER

AUTHOR OF 'A YEAR WITH THE BIRDS,' ETC.

\section{ב⿺辶一ำก}

\section{MACMILLAN AND CO.}

AND NEW YORK

1895 

OLIVERO V. APLIN, ARTURO H. MACPHERSON, HERBERTO C. PLAYNE, AVIUM AUCUPISQUE AMICIS. 


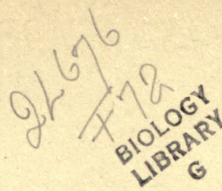

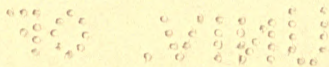

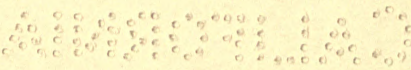


OLIVERO V. APLIN,

ARTURO H. MACPHERSON,

HERBERTO C. PLAYNE,

AVIUM AUCUPISQUE AMICIS. 



\section{NOTE}

In my last eight or nine long vacations I have occasionally found time to write a lecture for a Natural History Society, or a paper for Macmillan's Magazine. The present volume-I doubt if I can justly call it a book-consists of a selection of these lectures and papers. Most of them have been in print before, but where it seemed advisable I have altered and to some extent rewritten them. All were written in the leisure of summer days (counting September as a summer month), with the exception of the first, which I have prefixed as a kind of prologue to the rest. I should add that Chapter IV. was published last December in the form of a pamphlet by my friend Mr. Blackwell of Oxford.

Chapter X. has to do neither with birds nor books. But the subject of that little memoir was all 
his life in very close relation both with birds and ornithologists; and as I am told that his biography gave pleasure to many of his old friends, I have allowed it to find a place in the volume.

W. W. F.

KinghaM, Oxon., 6th October 1894. 


\section{CONTENTS}

\section{CHAPTER I}

Getting Ready

PAGE



CHAPTER II

To the Engstlen Alp once more . . . . 18

CHAPTER III

Among the Birds in Wales a . . . . . 46

CHAPTER IV

The Marsh Warbler in Oxfordshire and Switzer-

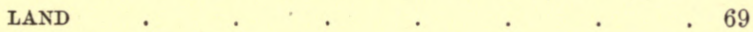

CHAPTER V

A Chapter on Wagtalls . . . . . . 96

CHAPTER VI

ON the Songs of Birds 


\section{CHAPTER VII}

A

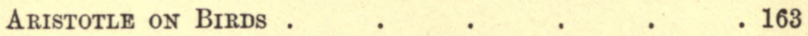

CHAPTER VIII

Gilbert White of Selborne $\quad . \quad . \quad . \quad .203$

CHAPTER IX

BindoN HILL . $\quad . \quad$. $\quad . \quad$. $\quad . \quad 225$

CHAPTER X

Billy : a Memolr of an Old Friend . . . 244

CHAPTER XI

Departing Birds : An Epilogue . . . $\quad 260$ 


\title{
CHAPTER I
}

\author{
GETTING READY
}

\section{A March Day's Diary}

March 17th, 1890.-Life in a town is on the whole comfortable, convenient, and warm; but how difficult it is there to get a sight of anything but your street, and a section of a cloudy heaven above it! You must be content to see your sunset caught by a church-steeple; you search in vain for a cross street at the end of which the full blaze in the west can be enjoyed. You would hardly know, but for the weathercock, what wind is blowing, unless, indeed, it be a grim north-easter; for the breeze that blows steadily in the country loses its way at the streetcorner, and comes twisting round in most uncertain trepidation, trying to get quickly out of this unwholesome labyrinth without regard to its proper direction. And you are quite in the dark as to what that wind is doing in the open country. Our \& 
street may be sloppy with a plaster of half-melted snow, while a mile out of the town all is fast bound in frost; and a man may con his books or his accounts unconscious of disturbance, while a full gale is roaring on the distant hill-top.

To get out of a town usually needs something of a struggle, but the struggle does not last long. When the noisy chaos of the station has been left behind, we glide out into the fields with just that sensation of calm that I imagine a duck must feel when it slides softly into the water after a period of waddling and quacking. We can sit back and survey such part of the sky as the window of an English railway carriage reveals to us; and almost at once we begin to divine that Nature is getting ready. For here and there, though it is but the middle of March, dark drifting curtains of filmy cloud are driven slantingly along the horizon by a wind from the south; and these are nothing less than the forerunners of April showers. The grass of the meadows is getting green, and the ploughlands are red or ochreous beyond their wont; and as we pass a certain familiar cutting I feel sure that the sweet violets are coming into bloom in the short turf above it.

And when the half-hour of travel is over and we mount to the railway-bridge and let our eyes wander in unobstructed freedom round the whole 
country-side, all these impressions are in an instant verified; Nature is really getting ready for summer, and all things animate and inanimate are at work for her.

A few weeks-nay, a few days ago, as I walked up this same road, everything was still; hardly a human being was to be seen, and the country wore that dull and unvaried look that sunless days in winter always give it. Now there is life and stir all round us. At the inn by the station there is a sale of cattle, and the road is beset with bullocks and pigs, all afflicted with that perverseness which these occasions bring out in them so strikingly, to the detriment of the moral character of their drivers. From the other side of the hedge comes a subdued chorus of bleating, and now I see that three adventurous lambs, who have passed the age of infancy, have forced their way through a gap, and are trying to see something of the world in a busy high road. No shepherd is near, and I take on myself-and a first delicious taste it is of country life-to drive these children back into their nursery, and to fence up the gap with a stray stick or two out of the hedge. Then, as the road turns sharp and brings me face to face with the village at a half-mile's distance, I see black objects crossing the sky in every direction, but moving always either to or from the elms and sycamores that cluster round 
CHAP.

the church tower. As the leafless trees stand out against the light, every nest is revealed; and I see at once that the same change is going on which we have noticed of late years, that the Rooks are gradually leaving the once favourite elm, and that the competition for the favourite sycamore must be a very trying one this year. The tree is not a big one, but there are a score of nests in its highest branches. It is a middle-aged tree, robust and compact, while the elm, as the Rooks no doubt can guess by its increased swaying in a high wind, is verging towards the evening of its stately, unvexed existence.

A little further up the road, on a warm bank facing the west, I see here and there the golden star of a celandine peeping rather shyly through the grass. Our country is high and rather bleak, and I have known some part of even April pass without a single celandine meeting my eye. When that does happen, I know that the keynote of spring is struck. I must go some way to find primroses or violets, and so it is that I look out for the celandine with far greater interest than for these. It is like the Chiffchaff among birds; neither is very fashionable, but each is very convincing.

Here are the village allotments, in two valuable fields of a dozen acres in all. Great is the change since I was last here. Then they were a sodden and 
untidy prairie of old cabbage-stalks, occasionally varied by the ruins of a scarecrow-some old hat or bonnet perched on the top of a pole, sloping westwards to show the prevalence of east winds of late, or a string bedizened with fragments of colourless cloth and ribbon stretched between two crazy sticks. Now these allotments are full of living creatures, all getting something ready. The human beingswomen, many of them-have already cleared away most of the cabbage-stalks; and now in the sunlight the stretches of freshly-dug earth gleam rich and brown, nay, almost red, where the digging is only just finished. This same earth was in the dead of this damp winter a sodden sticky black crust, beaten hard with rain, and greasy with decaying vegetation; now it is changed and fresh in colour, smell, and touch.

Here too the Rooks are very busy - so intent upon their work of clearing off grubs and worms from the newly-turned soil that they fear neither human beings, with whom at this time of year they seem to feel a fellowship of labour, nor the obsolete scarecrows which they have long treated with contempt. And over the allotments, at a well-maintained height of seventy or eighty feet, the traffic of these black labourers is continuous and worth watching. From their trees they must pass over the allotments, and then over a little valley and 
stream, to reach a vast extent of plough-land, which in two or three weeks they will be clearing of grubs for their young. At present many are still at work on the nests, and from meadow and plough-land alike they come home slowly, bearing burdens of all kinds, deposit them in the nests, and after a bit of wholesome quarrelling are off again at a far quicker speed. On a rainy day I have timed them each way, and found the return journey always much the slower of the two; and well it may be, if they will persist in carrying articles three feet long, like yonder bird, whose efforts to convey himself and a long curved stick through a high wind result in a series of tacks and tumbles ludicrous to behold. Why did he seize it at one end, instead of in the middle?

There is one change, however, which has not taken place in the allotments; and, as this is the solitary exception where everything is getting ready, it seems to demand a word. The gate by which every one has to enter-a gate on that account much used and abused-is what we expressively call here so very shackety that I should never suppose it capable of living through another season, if I had not already known it survive so many. It has been so often patched up that one might doubt, as the philosopher did of the sacred ship of Athens, whether it is any longer the same gate it was five 
years ago. It can be latched with a great effort, and then it hangs tolerably secure; but no sooner. is it unlatched than it subsides downwards in a palsied helplessness; its timbers all seem to fall away from each other, and you have to drag it groaning through the mud before you can open a space sufficient to pass through. Its distemper is chronic, and no one seems to know what doctor to call in, or who is to pay him. Pitying this ancient and decrepit servant of the village, I myself usually jump over the low loose wall by the side of the gate-post; and here it was that one day I nearly put my foot on an open book which was lying on the top, with a couple of stones on the pages to keep them open at one place. I was in a hurry, jumped over it, and was going on; but, thinking it an odd circumstance, I returned and looked at the book. It was an old Bible, without its cover and not indeed complete; but it was open at the third chapter of Nehemiah, and my eyes fell upon these words: "Moreover the old gate repaired Jehoiada the son of Paseah, and Meshullam the son of Besodeiah; they laid the beams thereof, and set up the doors thereof, and the locks thereof, and the bars thereof." There is much more to the same effect to be found in this chapter; and though no ardent Jehoiada, no thoroughgoing son of Besodeiah, has since then appeared in our allotments, this inar- 
ticulate cry for help has produced at least a little fresh patching. Who it was who thus preferred to let his Bible speak for him I know not; probably some old fellow, for I doubt whether the rising generation, when once they arrive at the haven of the fourth standard, ever care to set out on their travels in anything that can be called a book, much less in that one which was the only spiritual guide, the only earthly literature, of their fathers for many ages. "What we borrow from a thousand books our fathers were forced to borrow from one"; and our fathers are still living in their descendants in many a remote village.

In the whole of the allotments this poor gate is the only object that is not being touched to-day by some kind of a newness of life, for even the stone wall itself can show a few stray weeds or grasses beginning to shoot out of its chinks. Let us leave it and stroll round the further fields before the sun leaves us; it is quieter there, and we shall hear what birds are singing.

The first song we hear is a Chaffinch's, and it is a song about which I have something to say. This bird has indeed for some time been getting its song ready, and now, in all the splendour of spring plumage, is singing it without a mistake all round us; but do not suppose that it has been able to achieve this without hard practice. I have never 
seen the process described, and even of bird-lovers but few, I fancy, notice it; so it may not be amiss to put it down here. It is usually in the first week of February that I catch the first feeble effort, on some sunny morning in the Broad Walk at Oxford; but if the weather is fine I listen even earlier, and this year I heard the welcome sound on 31st January in the same place. To show how a single warm day will produce the same effect in different places, I may mention that a letter but just now received tells me that it was on the same morning that the Chaffinch began to sing at Cheltenham. Mr. E. J. Lowe, writing from Chepstow to Nature, a short time ago, stated that his chaffinches never quite dropped their song all this last warm winter; and in South Wales I have heard a fragmentary version of it as early as 18th January.

Very fragmentary indeed is it when I first hear it at Oxford. Let me explain it by a comparison which may be startling, but is none the less useful. Some of my younger friends who have learnt a song or two from me know the Chaffinch as " the bowling bird," because the only strain it can sing resembles the normal action of a bowler at cricket. Two slowish steps, three or four quicker ones, and a delivery made with some effort, describe fairly the bowler's action; two slowish notes, three or four quicker ones, and a jerk or twist of the voice-a 
quick rise and a fall-also make up the full and normal song of the bird. Now, when the practice is beginning, it is just as if an old bowler who had been laid low, let us say by influenza this sickly season, were to find himself incapable of getting much beyond his first two steps. When he gets into the quicker ones he comes to grief from weakness, and the ball drops from his hand. So with the bird; it is really more from the tone that I divine he is at work, than any recognition of the old familiar strain. But when I have once made sure, I listen and hear him struggling to get on a bit, rushing valiantly at his quick notes perhaps, and only stopping short at the final jerk. If the next morning be fine, I shall no doubt hear even this last crowning glory of his song feebly hinted at; and then, having got so far, an ardent and assiduous bird, who wishes to be beforehand in his courting, will sit on the same branch for an hour together and "bowl" away in the wildest fashion, wide of the net at each delivery, frequently collapsing entirely in the middle of his action, but ever returning to the charge, determined to hit the wicket before he leaves his perch. I have often been the only audience while this has been going on, and once I remember laughing out loud at the absurdity of the performance. To any one who knows well the full and perfect song, there is nothing more comical in 
nature; yet the bird is very much in earnest, for much of the coming season's happiness may depend on the results of this persistent practice.

Why the Chaffinch should stand alnost alone among birds in the trouble he has with his song, is more than I can explain; I know at present but one other whose song is not almost perfect from the first day of singing. If I am to make a guess, it would be that this bird's song is curiously stereotyped to a particular form, which needs an effort each time it is gone through, and that to get it perfect a fair amount of warmth and bodily vigour is necessary; while others, whose musical range is more elastic, can accommodate their voices to their bodily condition without producing ludicrous results. And I may call the Yellow-hammer as a witness to my theory; for he, whose song is also stereotyped in one mould -that which is familiar to us all as "a little bit of bread and no cheese,"-will rarely bring out his "cheese" in his first spring effort, and is at all times liable to drop it, if he be in a lazy or melancholy mood.

Other birds are singing-Thrushes, Robins, Dunnocks, Wrens, Greenfinches; whose voices, already perfect in execution, need no comment in this chapter. Let us notice what else is getting ready, in these fields that slope down to the brook. The Starlings seem to be in a state of transition, as be- 
comes them about the equinox; of course they have been getting ready for weeks, but some at least of them stick to their habits of the winter, for there are flights of them hurrying westward to their roostingplace beyond the hills, where the sun will soon be setting. Birds that can still do this have hardly yet begun to nest.

It is really in the grass and the plough-land that I see most change since my last visit. This meadow slopes before me to the west, and the sun, now close on the hill-top, fills all the grass with light, making the old brown tufts stand out distinctly amid the fresh growth of to-day. Those old tufts remind me of snow, and of Keats's hare that "limped trembling through the frozen grass"; these warm, green patches, of the boundless growth of buttercups that is to come, of exhausted cows on a hot June day, of all that wealth of summer rain that no farmer seems to be able to foretell and anticipate. Thought might wander on at will, but my eye catches a new token of business (in the real sense of that sorrily-handled word) in the abundant mole-heaps that crowd the slope a little farther on.

These indefatigable little animals have been at work since January, when their favourite huntinggrounds suddenly showed an eruption of little brown hillocks; and now you see here and there among these a small stick thrust into the ground, which 
marks the spot where a trap has been set. Numbers are caught (their death, let me say, is almost instantaneous, for their lives seem to be always hanging by a very slender thread which can be broken by the slightest tap with a stick); but this seems to make little difference, and every morning shows a fresh eruption. Mark Pattison, who was fond of puzzling people, once told me that he had "posed" a distinguished man of science by asking him why the moles in our vast Oxford water-meadows are not each winter destroyed by the floods. Certain it is that, in spite of the worst deluges we ever suffer there, the moles are on the spot again as soon as ever the water has cleared away. Ever since then I have kept an eye on the mole-heaps, and in fact have often wandered up and down these valleys, noticing their lie and order in the meadows; and find that these wary creatures do not often trust themselves out of reach of all means of retreat to higher ground. They live for the most part in those pleasant gentlysloping fields that lie just above the flat alluvial meadows; and here or in the adjoining hedgerows you find their winter homes-huge mounds with a convenient series of passages, and with a warm nest of cut grass in a large chamber deep down in the centre. Hence they issue forth on hunting expeditions after worms in the water-meadows; for worms and water are their two chief wants. Once or twice 
I have found their fortresses in what at first looked a perilous spot, in the flat ground close to a stream ; but never in any place constantly liable to flood. And here, where we stand now, looking down on the little green valley with its brook, I can clearly distinguish the parts where the water is apt to lie for a day or two in wet weather, by the entire absence of mole-heaps.

And now the sun is behind the hill, and we will turn homewards by the path that skirts this ploughed field, whose freshly-harrowed surface shows red lights and shadows in the sunset, reminding me of the coat of a little red Devonshire cow. The deeps and hollows in that almost furry coat have a way of treating the sunshine which was a constant pleasure to me when staying at an Exmoor farmhouse; and here is the same rough broken surface, changed from brown to various reds by the sunset behind me. Still more magical is the work of the sunset on the blue smoke that is now rising in every direction from the allotments, when the labourers are setting fire to the heaps of weeds they have been collecting. It drifts quietly away with the evening breeze, and spreads over the whole land; and then, as the sun sets, a wonderful transformation scene takes place. All outlines lose their clearness; all strong colours become subdued; all objects are seen through a soft veil of pale violet, which clothes the whole country- 
side in such a tissue of quiet russets and lilacs as I will not attempt to describe. It is this weed-burning which makes the dullest open country so beautiful in sunny evenings of March and September, and always forbids me to shut up my windows until the light has almost vanished, and I can see nothing but a flame breaking out here and there from a heap whose moisture has at last been exhausted in smoke.

The process of getting ready involves the destruction of old things, as well as the appearance of new ones. As with the vegetation of last year, so too with the human population of our village. One or two at least of our oldest plants are sure to fail and die before each spring comes round. In particular I miss one old acquaintance-a gamekeeper in his younger days, who had a good deal to tell of birds and beasts, and will go down to posterity in $\mathrm{Mr}$. Aplin's work on The Birds of Oxfordshire. He was fond, like the inimitable ancient maltster in Far from the Madding Crowd, of telling you of his great age, and $I$ once asked him if he remembered anything of the Waterloo times. He looked round at me with the one eye he possessed, and said tentatively:

"'Twas Wellin'ton as won the prize at the battle o' Waterloo, wasn't it, sir?"

I assured him that his memory had not deceived him. "Ay," he went on, "but 'twas old Blucher (he pronounced the 'ch' soft) as done all the vightin'; 
why, Wellin'ton was a-dancin' away at a ball till old Blucher come up!"

Where Mr. Cook got hold of these odds and ends of truth I have no idea. He is now gathered to his fathers, and has vanished away from us like the smoke.

March 18th. - Another beautiful and sunny morning, though the wind is veering round to the east. A stroll through the fields brings me to a hedge which has lately been lopped; the superfluous branches are lying on the grass in bundles. It is one of our warmest spots, and I am always on the look-out for birds there. I have just been watching those birds of winter, the fieldfares, gathered in numbers on some trees, and chattering excitedly as if they were about to leave us. Suddenly a little brown thing flits out of one of the bundles of branches, hovers a minute in the air, and returns to shelter. There is not a bird among all our winter residents that would flit into the air like that, nor one that would creep among the twigs exactly as he is creeping now. Out he comes again, plays in the air for a second, and alights on another bundle a few yards further on. I have no longer any doubt, but my glass makes assurance doubly sure; it is the Chiffchaff, the first of our summer birds, the first traveller to reach us from Africa and the warm south. He seems to have divined that we have been early in 
getting ready for him, and has accepted our invitation at an earlier date than I ever remember in these uplands. He has probably come up the valley, following the windings of the stream, where he can always find both insects and shelter. At this point he has left it, and is making his way up the hedges till he arrives at his last year's home, where he can await the later arrival of a bride; soon his merry double note will be heard from elm or wood-side, announcing that all is ready for her. 


\section{CHAPTER II}

\section{TO THE ENGSTLEN ALP ONCE MORE}

I HAVE written of the Engstlen Alp before, and it may be that my readers have heard enough about it. I am nevertheless going to please myself, and to tell what I have met with, there and on the way thither, since A Year with the Birds was published in 1886. Up to that date I had no bird-loving companion in my mountain rambles, except my faithful old friend Johann Anderegg; I had to identify all strange birds as well as I could, with the aid of public collections and standard works like that of Mr. Dresser. Of late I have twice been fortunate in the companionship of ornithologists : one a ripe scholar in the craft, whose eyes, ears, and note-book were ever in vigorous use; the other a younger enthusiast, gifted with such powers of climbing and nest-finding as I have not been able to lay claim to these twenty years and more. Knowing where birds were to be looked for, I in each case contrived to satisfy almost all their aspirations; and in return they dis- 
covered for me much that I had missed in former years.

Englishmen now know something more of Alpine birds than they did eight years ago; Mr. Seebohm, Mr. Howard Saunders, and Mr. Scott Wilson have all contributed to the subject, and the last-named in particular has thoroughly explored the Engstlen Alp in May. ${ }^{1}$ But the world of travellers is still apt to find but little wild life in the Alps. Few can travel in May or June, when that life is in its fullest vigour ; our English holiday time is August, the very deadest month, for an ornithologist, in the whole year. I grieve for schools and schoolmasters, and think with regret of the good old time when there were but two terms in the school year, and we could throw our books away in mid-June. Would that I could take some school Natural History Society to the Alps before June is over, and give them a succession of glorious field-days where Nature has but just awakened from her winter sleep, and lies in the sun undisturbed by tourists !

Every. one would find work in abundance. Switzerland is indeed a wonderful country, and it is not only its mountains that are wonderful. Its history is wonderful : its system of government is wonderful : you can study man there if you will, as well as animals, or plants, or rocks. You never

1 Ibis, vol. xvii, p. 103. 
know what wonders may not meet you there. One year I suddenly found myself in a little revolutionvery small of its kind, like so many alpine plants, yet a complete and determined revolution, full of political interest. Once my way was blocked by the sudden breaking out of a great glacier lake, and next day I had to cut steps in ice which the rushing water had polished like a looking-glass. I have seen quiet lakes torn up into foam, lashed with rain, and illuminated with incessant lightning, and have been for an hour in a steamer in the very centre of the storm. You are constantly on the tracks of flood, and landslip, and avalanche; you see Nature working everywhere with a mighty hand.

Yet in such a spot as the Engstlen Alp, on a fine June day, the rest, and peace, and fragrance are delicious. I have known the alp for twentythree years, and, though it has seen its changes and is a trifle more civilised than of yore, I can enjoy it as well as ever before the crowds descend upon it. I venerate the name and memary of the man who first told me of it at Nancy in 1871; I have never seen him since, but if he should chance to read these lines, I shall feel that I have discharged my debt to him.

Let us then set out for the Engstlen Alp, noting on our way such objects as the ornithological 
traveller would not care to miss. Even from the train window, as we cross those vast expanses of well-tilled land in Central France, something may be seen ere nightfall ; the Hen Harrier, for example, a fine bird now almost extinct in England, may be quartering the fields for his evening meal. Early in the morning, as the train winds slowly up the passes of the Jura on its way to Bern, you may form some idea of the common bird-population of the district; Whinchats are in the hay-fields, Black Redstarts on the chalets, and Dippers and Gray Wagtails by the swift streams we cross. At Biel, where we descend to the plain of Central Switzerland, it would be worth while to alight and spend a day or two of search by lake and river; but if time be precious, and if we would see what the true Alps have to show us, it is better to go on, spending only a few hours at Bern-a delay that will be well repaid.

Bern is generally known as a city of bears-of bears in stone, bears in wood, and live bears in a pit. But there are birds in Bern as well as bears. The town might well have Swifts on its coat of arms; these birds rejoice in its bright, invigorating air. The streets and squares resound with their shrill voices, and they nest under the eaves of the hotel I frequent. These are of the common species; but if you stand anywhere near the cathedral and 
look up, you will see, generally higher in the air than the others, numbers of the splendid Alpine Swift, circling round with marvellous speed. You can tell this bird at once by his white belly, which almost glitters in the sunshine, and by the ease and dignity of his flight; he does not use his wings so rapidly as the other, but sweeps along almost without an effort; and he does not scream so wildly, but whistles to his sitting mate as he sails around the tower, or utters a crescendo chatter, which seems to end fortissimo as he comes near to you.

This first bird we meet with is such a noble one that I must dwell on it a little longer. It counts as a British bird, but has been rarely indeed found in our island. It should never be mistaken for the common species; the white belly, and a brown band across the breast, mark it at once. The back, too, is much browner, as we noticed when they descended below the level of the famous cathedral terrace, and allowed us to watch them from above. These are surer tokens than the mere difference of size, for there is nothing more deceptive, sometimes even to an experienced eye, than the relative size of birds.

The true homes of this Swift are among the mountains both of Europe and Asia, where it builds in caves and deep crevices of rocks. But, like some 
others of its kind, it has found out in Bern and a few other cities that man's architecture suits it even better. What can be happier for such an aerial bird than to be able to sweep round and round a lofty tower unimpeded by walls of rock? So it has come down from its mountains to the plain, and taken possession of the noble tower at Bern. There it builds a curious flat nest, formed of dried leaves, bits of paper, and of fir-bark, with a few feathers, on beams and ledges within the tower. Like the Chinese bird whose nest is eaten in the East, it secretes a saliva with which to glue these materials together; for in wind-swept caves and towers they could hardly be held together without some such device. The glutinous mass is very apparent in the nests exhibited in the Museum at Bern, which are hardly pleasing in appearance, being not unlike a series of ancient and gruesome cheesecakes well flattened. The eggs are pure white, and of an elongated oval shape. ${ }^{1}$

When I was last at Bern we did not stay there long, but went on in the afternoon to the Hotel

1 Mr. Scott Wilson, who himself ascended the tower in 1885, has well described the nesting-places of this colony in the Ibis of April 1887. I extract a sentence or two:- "The nests, of which we could see about twenty, were placed on the ledge which goes round the tower (i.e. inside), and about four feet below the main floor on which we were standing. . . . Sometimes there were three or four in the space of three yards, all placed on the same beam, and on most of the nests we could see an old bird sitting." 
Bellevue at Thun, where there is an extensive garden. Next morning I was out before breakfast in this garden, and soon heard a voice that was new to me. If this happens after May, when all the foliage is out, I know I may be teased for a while, and so it happened that morning. Wherever I went, there was the mysterious voice-clearly that of a very small bird, feeble and shrill, though contented and unobtrusive. Five little syllables of different length were constantly repeated, getting a little higher in pitch towards the end: "twee-tweetw-twee-t." It was late in the morning when I found that it was nothing in the world but our common little Tree-creeper. Now, I can count on my fingers the number of times that $I$ have heard the Creeper sing, and on those rare occasions in England I have never heard the notes I have just described. But there is no doubt that birds speak with a different accent in different localities; the Chaffinch, for example, will do so, and I have been puzzled for a whole morning in Italy by a Chaffinch with a strange call-note, who would not show himself. Let us note, by way of a possible explanation of this uttterance of the Creeper, which I have since heard elsewhere in Switzerland, that this bird does not migrate, but probably remains in the same district all his life. Surely it would be more natural for non-migrating birds to develop some new habit 
of speech, than for those which change their residence with the seasons. They are in a certain sense isolated species, and, like some of the birds which never leave our island, they may take up peculiarities of their own, in voice as well as colour.

Just above the garden, on the wooded slopes which shelter it from the north, we heard another voice, which was familiar enough to me, though at the first moment on that occasion I misinterpreted it. It was seven years since I had first heard this song-if song it may be called-a quick sibilant trill, which I may describe to those who know the songs of birds as half-way between the song of the Wood-wren and that of the Lesser Whitethroat. When it first attracted me on the wooded hills above Meiringen, it seemed to be uttered in varying tones, now here, now there, and sometimes close to me; but the singer would not show himself. Three years later I came to this same place again, and again heard the bird, and many others of his kind, and confirmed my earlier conjectures. He was Bonelli's Warbler (Phylloscopus Bonelli), a near relation of our Chiffchaff, Willow-wren, and Woodwren. He is a Wood-wren, with little of the Wood-wren's yellow tints; a Willow-wren, with a purer white breast and longer wings; a Chiffchaff, with lighter coloured legs, and a rather longer body 
and tail. He seems to come nearest to the Woodwren among these three Phylloscopi in two other particulars; his song is not unlike the Wood-wren's "shivering" strain, and he uses no feathers in the lining of his domed nest. I found this nest in 1889, after a long hunt in wet grass in a wood; it was on very steep ground, in a hole under a projecting stone, and contained one egg, dull white in groundcolour, with rich chocolate-coloured spots, chiefly at the thicker end. At Thun my friend's sharp eyes found it almost directly, in a very similar position on steep ground in a wood; the eggs had been already hatched.

This modest little warbler is essentially the Phylloscopus of the Alps. Just as with us the Willow-wren is far the commonest of its group, and may seem almost to be crowding out the Chiffchaff and the Wood-wren, so in the Alps Bonelli is to be found everywhere, the other three only here and there. I have only heard the Willow-wren in the flat of the valleys, where Bonelli is not often to be found; but on all shady hill-sides the latter is quite abundant, and you have him with you from the moment of leaving the valley, up to a height of four or even five thousand feet. This is clearly a hardy bird, and one that has been long known to be extending his range northwards. $\mathrm{He}$ is to be found in Southern 
Germany, and even in Western France $;^{1}$ and why should he not some day venture to cross the sea to England? Let us hope that he will come in my time; for I count him as one of my especial favourites, and should be glad to think of him as included in our British list.

On our way from Thun to Meiringen in 1891 we stayed a few hours at Interlaken; but as I have described in another chapter how we discovered the Marsh Warbler's nest there, I will only delay to tell of one trifling incident which carries a moral with it. As we went down the road towards the marshy tracts by the Lake of Brienz I found a Yellowhammer's nest, containing young, in a hedge by a much frequented path. It was within arm's length of every passer-by, and was as obvious as any nest could be, yet unmolested. No one takes nests and eggs in Switzerland, nor wishes to do so; the habit seems never to have grown up among the boys. Mr. Howard Saunders, in his Swiss notes in the Ibis, tells of a Dipper's nest which he watched for several days at Lausanne, until some boys came and promptly tore it down. But who were these malefactors? Need it be said that they were British boys from a neighbouring cramming establishment, relieving their

1 My friend Mr. H. C. Playne found this bird near Luęon in April 1894 (Zoologist, August 1894). It has twice occurred on the wonderful island of Heligoland. 
mental indigestion by giving the fling to their native barbarism?

At Interlaken, and again at Meiringen, which we reached that night, we paid special attention to the nests of the House-martins. My old friend Anderegg, who has lived at Meiringen all his life, has often told me that these birds always build there under the ledges of rocks, and never on houses; and in fact the name by which they are known in the valley is Fluihspie or Rock-martin. As here and there in England, they have held to their original and natural habit, and have not been tempted by the buildings which man erects. But this year we were able to show Anderegg several nests built under the eaves against timber, and he was obliged to believe the evidence of his own eyes. It may be that this had been going on some time unnoticed by him; it had become a fixed idea in his mind that the bird builds in one way, and it would not occur to him that circumstances may possibly induce it to build in another. He would not be likely to reflect that a change in the character of human architecture may have led the Swallow tribe to take advantage of it. Now, within my $q$ wn recollection of Meiringen there has been a marked improvement in the architecture, - not indeed in the beauty of the buildings, but in their size and substantiality. When I first knew it, it consisted almost entirely of very 
old sunburnt wooden houses; but about fourteen years ago it was destroyed by a great fire, and arose from its ashes a handsome village, with several great hotels of stone, and many large wooden houses sheltered by overhanging eaves. I think it is a fair guess that the Martins have begun to be attracted from their rocks by this change in the architecture, as their forefathers were long ago by the temples of the Greeks and Romans, or as their American cousins by the buildings of European colonists. ${ }^{1}$

If any of my readers should find themselves at Meiringen, let them make one easy expedition before they leave it for the Engstlen Alp. Let them take the train down the valley to Brienzwyler, and walk, as I did with old Anderegg and a friend last year, up the road which there leaves the valley for the Brunig pass. We came to look for Crag-martins, which nest on steep cliffs above the road; we barely saw a Crag-martin, but we found something even better. Here is my note written on the spot, as I sat under the baking sun by the roadside, watching the perpendicular cliffs above me. "A butterfly-like creature fluttered on to the face of the cliff, and wriggled sideways along it into a crevice; then out again, and more wriggling; then he took flight, looking like a large moth, and showing wings on which we could see white, and once or twice some

${ }^{1}$ See below, p. 199 foll. 
crimson. This occurred twice, and it would be hard to get a better view." 1 It was a delightful moment, for this bird is perhaps the most singular, and in some ways the most beautiful, in all Europe. It is the Crimsonwinged Wall-creeper (Tichodroma muraria), which I had looked for repeatedly in places where it was said to breed, with no such good success as I met with on the last day of June. This bird, we felt sure, was feeding young when we saw it, and those young ones may be there next summer to greet the eyes of travellers.

We then followed the road to the pass, and leaving it there, we took a delightful route along the heights to the little hamlet of Hohfluih. This is the "fatherland" of the Woodpeckers; and you may almost always hear the loud cry of the Great Black Woodpecker high among the pines, even if you fail to see him; and if you will but wait a while among the ancient mossy sycamores, you can hardly fail to see the gray species (Picus canus), which is a total stranger to most Englishmen. This last bird has a hoarse cry which he repeats again and again as he nears you; he thus lets you know where he is, and,

1 The crimson is on the wing-coverts, not on the quills; it is therefore visible even when the wings are folded. There is a well-known insect of the locust kind in the Alps which wears the same colours as the Wall-creeper, ash-gray and crimson; but in this case the crimson is only visible when the creature is in motion. When it alights on a slaty rock, the gray colour acts as an infallible protection. 
if you lie quiet, may come quite close to you. He is not so handsome a bird as our Green Woodpecker; the colour he shows you is chiefly gray, with conspicuous yellow above the tail.

But it is time to begin our walk from Meiringen to the Engstlen Alp, and to escape, if we can, from the swarms of horse-flies which have been distracting us in every attempt to hold the glass steadily while looking at a bird; for in a warm June Switzerland has its drawbacks as well as its delights. With these was a larger bee-like fly, the bite of which was no light matter; and in 1893 these two pests were not only in the valleys, but at six and even seven thousand feet were still there to tease us, though in diminished numbers. Fortunately we found many insects on our route of a more friendly disposition. Butterflies showed themselves in marvellous numbers, if not in great variety. Before we began the first steep ascent, the Camberwell Beauty and the two species of Swallowtails, with the larger of the two Apollos, were the most conspicuous; then the Black-veined White (now almost extinct in England, though I used to catch it in Wales some thirty years ago), and the delicate little Wood White; Fritillaries, Arguses, and Ringlets were also in abundance.

But the most astonishing of them all, in numbers at least, was the tiny little Bedford Blue (Polyom- 
matus alsus), smallest of all British butterflies. We had found it in the deep valley of Meiringen; we found it all the way up to the Engstlen Alp, more than four thousand feet higher; it would collect in clusters on the path, in company with Skippers, and would pack so densely that a foot put down on the little crowd might have killed at least a score. And then again, when we had climbed above the alp to the highest region of all, from seven to eight thousand feet above sea-level, there it was still, flitting about among the patches of melting snow, and doubtless helping to fertilise the exquisite little alpine flowers.

Why, one may ask, should these alpine flowers be so intensely bright and fragrant, growing as they do in so cold a climate and in such wild and rugged spots? Mr. Wallace, in his Tropical Nature, ${ }^{1}$ tells us that they need these bright colours in order to attract the butterflies that fertilise them. If it be true that butterflies are really the agents of this reproduction, the theory seems a natural one, and explains the facts. There are few butterflies as high up as eight thousand feet; we saw, if I recollect right, only two species, the Bedford Blue and a small Fritillary, and these, though common, were not exactly abundant. There is probably, then, great competition for the services of these, and natural selection has been long and hard at work. The 
brighter and sweeter flowers have survived, and these have tended to become ever brighter and sweeter. When I was here in June 1891, there were white and purple crocuses, pansies great and small, great carpets of pink primulas, purple auriculas which love to gather in a cluster under some rock or bridge, oxlips, forget-me-nots, globe-flowers, and gentians light blue and dark blue, studding the ground everywhere. High up on the rocks and moraines it is the plants that cluster and form cushions which have come to the front in the competition; nowhere else do you find such masses of bright colour as in this highest region of life. It looks almost as if the plants cooperated with each other in good-will to do the work of attraction: so lovingly and hopefully do they gather in certain spots.

The Engstlen Alp, which all these flowers deck in early summer, is, I imagine, the terminal moraine of an ancient glacier once descending from the range of the Titlis, the bed of which is now in part occupied by the beautiful Engstlen lake. The rough and hillocky ground lying between the inn and the lake betrays its origin pretty plainly; it is now covered with the alpine rhododendron, and on the tops of the hillocks are pine-trees of immense antiquity, each sitting on a stone, as Anderegg is fond of pointing out. In these pines the birds take great delight; Ring-ousels perch on the very top 
CHAP.

twigs, with food for their young in their bills, uttering their metallic alarm-notes, and watching us suspiciously ; we found one nest in a stunted bush below, with young just ready to fly. ${ }^{1}$ Redpolls also build in these pines, and are at this time dancing about in families from tree to tree, twittering merrily. All that I have seen of recent years have been of the "mealy" form, as it is called; they were somewhat larger than our English Lesser Redpoll, and some of them had heads and breasts of the most brilliant carmine. But I still hold that a specimen which Anderegg shot here in 1885 was a genuine bird of the smaller race; it was extremely small, and very dark in hue.

On the top of these same trees the Alpine Pipit loves to perch, and thence to soar into the air and sing. It is generally the first bird we hear on our arrival, and very welcome the song always is; for it tells you at once that you are on the real "alps," in pure, cool air, within reach of snow. You rarely or never hear him until you have mounted above all dense woods and heavy grass, into the shortest and sweetest of herbage, in which he loves to place his nest. When last year we were scrambling at some height above the alp, my friend Mr. Playne came

I The Ring-ousels here, as Mr. Aplin pointed out to me, are of the alpine race, with something more of white on the wing than the common form. See Mr. H. Saunders' Manual of British Birds, p. 16, and Mr. Seebohm in Ibis, vol. vi. 309. 
upon this nest, on a steep bit of grassy ground, containing five eggs speckled with greenish brown. This bird is perhaps the handsomest of all the Pipits, and as he has been found some four or five times in England, he is a bird worth knowing, even if you cannot follow him to his native haunts. He has a distinct light stripe over the eye; his upper parts are gray, with a slight bluish tinge; his throat and breast are rufous, his belly white, and his legs black, or nearly so. The wing coverts are brown, and these and the secondaries have whitish edges which show in two bars on the folded wing; and the outer feathers of the tail have the white which is characteristic of almost all the Pipits and Wagtails. ${ }^{1}$

The Black Redstart is here, as everywhere else in Switzerland, at all heights up to the snow. I found a nest here, on a beam beneath the roof of a haybarn - a large, ungainly structure, as all nests are apt to be when built in such positions. Another nest, which was evidently in a hole in some big boulder, I utterly failed to find, in spite of careful watching; the old cock bird was far too wary for me. I call him old because he had a head and nape so very gray that in some lights it seemed almost white; and

1 This description, which tallies well enough with that of $\mathrm{Mr}$. H. Saunders in his Manual of British Birds (where this bird is called the Water Pipit), is taken from notes made in 1885 of a bird which Anderegg shot on this alp. 
it was really this, rather than the chance of finding his nest, which caused me to give him such close attention. This must, I think, be a sign of age, though I have not seen it alluded to in books; I have noticed it once or twice in other individuals, but never so distinctly as in this one. This bird had also another peculiarity : he had invented a variation on the regular song of his species, consisting of two introductory notes, which even Anderegg was sure he had never heard before.

There is a ridge of grassy limestone rock bordering the alp to the east, which gives one a splendid position for scanning the tops of the pine-trees in the valley below. Citril Finches and Crossbills will sometimes show themselves here, and you can hardly ever fail to see a Nutcracker. This is a very rare bird at home, but you soon meet with him in Continental pine-woods. He is not unlike a large Starling, and does indeed belong to the family of the Crowsa relationship betrayed by his odd, uncanny ways. I have seen him sitting on the top of a pine, croaking like a small Raven, and looking quite fiendishly knowing. Mr. Howard Saunders noted the same characteristic in him, and while watching one disposing of nuts in the autumn, was irresistibly reminded of Punch dealing with his enemies in the show. ${ }^{1} \mathrm{He}$ descends in the autumn from the pines to the hazels, 
and enjoys his change of diet. I have often found old split nutshells in these lower grounds, which were the results of his feasting, among others which had been opened by squirrels-these with a small hole drilled at one end. A Nutcracker's nest, I need hardly say, I have never yet found; I cannot search the pine-woods in March, and if I could, I might well search in vain. It is only of recent years that the nest has been discovered at all ; and the mystery which used to enwrap it is prettily illustrated by an old Swiss myth which told of a priceless jewel to be found in it. This jewel would make the finder rich and happy for life, but neither nest nor jewel had been found in the Oberland when the story was told me.

Before we stray further from the alp, let us return and see what other treasure it can produce for us. One evening we had for dinner some strange-looking fish from the lake, called by the natives Trüschen, with very big heads and long eel-like tails. They lie among stones by the edge of the lake, where you have first to stir them up with a long pole, then dangle a worm before them, and they will immediately take it, most eagerly at nightfall. We were puzzled by this fish, though very glad to eat him; and my friend Aplin, after triumphantly catching one, bottled him in spirits and took him home to England. $\mathrm{He}$ turned out, however, to be nothing wonderful-the 
Burbolt, a British species, but restricted to a few of our rivers. What is interesting about him on the Engstlen Alp is that he must pass the greater part of the year under a roof of thick ice with deep snow above it; and I presume that he buries himself in the mud and lies torpid.

There is another animal, very plentiful on this alp, which also sleeps under snow all the winter. I have never seen Marmots so close and so well as here in June; few visitors have been about, and the creatures have almost forgotten to be wary. Early one morning they were scampering all round us as we walked up to the Joch, looking much like longhaired dark-brown Scotch terriers; in fear, I think, rather than in play, for we smelt foxes strongly, and found their tracks on the snow. The Marmot is a perfectly helpless creature; every time he comes out of his hole he is in danger, and he knows it. When Eagles were commoner than they are now he ran risk from these, but foxes and stoats remain to persecute him. He goes rarely far from home, except perhaps early in the morning, and when he wishes to enjoy the sun, squats down on the grass by the side of his burrow, or on the top of the little natural rise under which it is often excavated. There he makes a form like a hare's, which is often slabbed down quite smooth by his weight and shaggy hair. The instant any danger threatens-a strange sound 
or moving shadow-he sits up with his paws in front of him, whistles loudly, and bolts into his hole. The whistle is astonishingly loud and shrill; even with my dull ears I could hear it half a mile away. How it is produced I know not; one book tells me that it is done by means of the two long incisor teeth, but of this I cannot be sure.

Chamois are not yet wholly extinct in this district; in 1891 we saw one for a moment, and I have frequently found their tracks in the snow, showing well the animal's strongly divided hoof. They may no longer be shot in this canton of Bern, and it may be hoped that they are getting more plentiful again. Among other vertebrate animals, vipers are here (though I have seen but one), and stoats, and alpine newts, and the curious black lizard-like salamander (Salamandra atra). These salamanders came out in great numbers at the close of a warm rainy day, and waddled clumsily about, tumbling down from the puny eminences they tried to climb, and trying to look like some inanimate object when stirred up with an alpenstock.

But to return to birds, let me tell of the most enchanting nest that I have ever seen, the discovery of which was due to my old friend the landlord's son; we were allowed to see it as being rational and privileged persons. I had long suspected that Teals visit this alp, but had never been able to prove it. 
Here, however, was a Teal's nest, hidden in a clump of alpine roses, through which you looked into a warm cradle of the duck's own feathers, containing seven beautiful eggs. A few yards off was a tiny pool, in which perhaps the young Teals were to have their first lesson in swimming.

Other interesting nests are to be found by those who, like my friend Mr. Playne, are able to climb in search of them, among the steep slopes and rocks which lead from the alp to the Joch pass, and in a stony hollow called the Schafthal lying between that well-known path and the craggy fortress of the Schafberg. On these steep slopes the Alpine Accentor is always to be found; you may catch his sweet warble as you walk up towards the Joch, or see him perched after his wont on the edge of some little precipice. He will leave this, and flutter about for a moment singing, while you watch ; or it may be that you will see a pair courting and pursuing each other,-for at this height they are late in breeding. The bird may easily enough be missed in one of those rapid walks that Englishmen think necessary in the Alps ; so too may that exquisite Narcissus of purest white which I found on the rocks while searching for the nest. But one clear leisurely June morning will not fail to reveal both bird and flower.

I have a strong conviction that this Alpine Accentor, the nearest and almost the only European 
relation of our common little Hedge-sparrow, will some day be discovered breeding among the hills of our own island. It has indeed been very rarely met with there at any season, but its sombre dress and retiring habits may easily cause it to be overlooked. If any reader, scrambling on some steep hillside, should see a bird a little larger than a sparrow which shows chestnut on the flanks and a slight double-bar of white on the wing, let him watch it very closely; and if it should presently perch on the very edge of a rock, and show him a throat speckled with black and white, he may make a good guess that he has the Alpine Accentor before him. For his benefit too I will transcribe an account of the nest found by my companion on the second day of search on the Engstlen Alp.

"One morning I clambered up the steep grass slopes to try and find a nest of the Alpine Accentor. Before I had gone very far I found a pair of these birds carrying food, and after a good deal of watching succeeded in finding the nest. The cock and hen were so much alike that I could not see any difference; they moved about slowly, flicking their wings in a restless way, and after I had been watching them some time, one flew away, and the other deliberately ate all the food it was carrying. In a short time, however, one returned, and soon went to feed the young. The nest was well concealed under 
a rock which projected from a very steep bank and was covered with grass. Some of this grass hung down in front and formed a screen. It was substantially made of short bits of dry grass and moss, and contained only a few feathers. There were four young, whose feathers were just beginning to grow ; when they opened their mouths, crying for food, I was able to see that there were two black spots at the back of their tongues." 1

As you lie up here among the flowers, watching the Accentor or listening to his pleasant song, a distant cawing may be heard far up on the precipitous rocks. Cawing I must call it for want of a better word, but it is more like the voice of a Jackdaw than that of a Rook, and reminds me for a moment of the thousand daws of the chalk cliffs in Dorset. Then you will see, far up in the blue above the rocks, one or two black specks; then half a dozen, then twenty; and meanwhile the foremost are descending and nearing you, sailing with a flight hardly less graceful than a gull's, until they alight by the side of sorne great patch of melting snow, and probe the watery edges with their bright yellow bilis. In such places there are insects in abundance, and such as will be good food for the young Choughs up yonder; for some thousand feet higher, on the precipices at the end of the Schafthal, Mr. Playne 
discovered their nesting-place, and saw young birds in immature plumage, with the bill black instead of yellow, and black feet instead of red. They are nearly always to be found here, appearing suddenly as I have described; and they are so tame that, if you lie still, and if no tourist happens just then to be descending from the Joch, you may have forty or fifty walking or hovering about you.

We are apt to associate the huge mountain-walls of Switzerland with birds that are themselves huge, -with the Lämmergeier, the Golden Eagle, and the larger Hawks. But, however it may have been in the past, these mighty robbers are not now the characteristic birds of the highest alps; a few Buzzards and Kestrels, with here and there a Raven, are all that as a rule the climber will meet with in a day's work. The typical bird of the peaks and glaciers is undoubtedly the Alpine Chough. $\mathrm{He}$ is the weather-prophet of the hunter in winter and of the guide in summer; he is thought by some guides to be a bird of ill omen: he is apt to come upon you suddenly when you are in difficulties on some stone-swept couloir or brittle arête. ${ }^{1} \mathrm{He}$ may be with you on the highest peaks-on the summit of Monte Rosa or the Finsteraarhorn. He may make a meal to-morrow on the relics of the supper you

${ }^{1}$ My informant is the Rev. W. A. B. Coolidge, Secretary of the Alpine Club. 
have been having at the club-hut, for like the Rook he is omnivorous, and needs be so to pick up a living in these wilds. $\mathrm{He}$ will eat snails, insects, and such small fry, when he has nothing better; but, like the rest of his race, he is ready to feast on the carcase of some creature that the hunter has wounded and lost, and to fight for his share of it with his sharp yellow bill. It may be that now and then he falls a victim to some bird of prey; but in a multitude there is safety, and as I have seen him teasing a Kestrel just as the Rooks will do at home, I think it not unlikely that he may be able to defeat the attacks of much more formidable enemies.

We shall leave the Choughs behind us as we descend from the snowy heights of the Joch; we shall leave too the Ptarmigan and the Snow Finches, the two other species which are to be found only where snow is still lying or where it has but just melted. As we descend towards Engelberg we may again hear the Accentor and the Alpine Pipit; then on the Pfaffenwand the bright voice of the Chiffchaff will be almost sure to tell us that we are nearing the woodland, and a little farther the Tree-pipit will greet our return to his own country, and the ubiquitous Chaffinch, and many another. We are again in the regions of civilised bird-life; what we see here we have seen before, and our ten days' work is done. An Alpine Chough down here would be a lost bird : 
"Non altrimenti stupido si turba

Lo montanaro, e rimirando ammuta,

Quando rozzo e salvatico s'inurba."

But the recollection of the montanari will live with us through the winter, and another June may show, if all be well, that the Engstlen Alp has something yet to teach us. 


\section{CHAPTER III}

\section{AMONG THE BIRDS IN WALES}

In the flat meadows of the midlands, with their deep alluvial soil, there is a certain lush richness of vegetation in June which makes the air heavy and languid. Unless the weather chances to be unusually dry and bright, as it was in the June of last year, you cannot push through even a few yards of that dense herbage without feeling the moisture that lurks in the depths of it; the same moisture that becomes visible, when the sun goes down, in a white film of vapour which rises ghost-like in the dusk, and covers the meadow like a sheet, ending exactly where the hedge divides the upward-sloping pasture-field from the growing hay of the flat ground.

It is at this time, before the hay is cut and the damp of the grass-roots is exposed and dried, at the very time when the flowers are most brilliant, and the gently-flowing water of our streams lingers lazily about the yellow flags and blue geraniums that 
fringe the banks - it is in the very height of the glory of midland verdure that I always feel a strong desire after light air and short grass. To mount to some height overlooking the plain, where in an old quarry the rock has been overgrown with thyme, or where on the broad strips of grass that border the road some remnants are still left of the old flora of the down-land, is to me at this time always a delight and a relief. Should there chance to be a corner where a few tufts of heather still linger among the furze-bushes, and where perhaps a little copse of pines varies the almost wearisome landscape of hedgerow elms and growing crops, then it is pleasant to lie for a while and listen to the Linnets or watch the handsome Stone-chat, picturing to oneself the time when half England was like this little nook, and when no one delighted in his wealth of wilderness as I do in this scanty remnant.

But for those who can get a holiday in June it is possible to go farther away from heavy air and sleepy days than to the top of the neighbouring hills. In June the Alps are clothed in their wealth of flowers, and every breath of air is laden, not with rich sweet odours, but with dry, invigorating, aromatic deliciousness; and many a time have I made my pilgrimage thither, to find the short grass I long for, still uneaten by the cows, and gay with a thousand blooms. Quite as enjoyable, and less far to seek, is 
the still shorter grass of the chalk downs of southern England, those

\section{"Russet lawns and fallows gray, \\ Where the nibbling flocks do stray."}

For there the light air comes from the sea; though not iced, it is fresh with the salt water; and as it breathes through the long bents and gathers the fragrance of the thyme, it dries up every tiny drop of moisture that has not already sunk into the porous soil, and gives you free leave to throw yourself without a thought of consequences on the grass, within an hour or two after a scudding shower has refreshed the thirsty down.

One languid June, when duties came to an end at Oxford, it so happened that I could not seek the light air and short grass I longed for, either in the Alps or on the downs; and it was only an accident that took me for three or four days to a hospitable house in the Welsh hills, where I found all I needed. It was a district offering little of the "striking scenery" which attracts the tourist, and he is almost unknown in those parts; there is in fact no accommodation for him. During a six weeks' stay in the wildest part of these hills some twenty years ago, working hard and trying to beguile unwilling trout, I saw but one pair of tourists. You may walk for miles over high wet moorland and never 
strike a track; you may very easily lose yourself and follow down some brook which, with a gradual curve, will take you in the opposite direction to the point you wish to make for. And if rain and mist come on, as they did one summer evening years ago, when I was crossing from valley to valley by an ill-defined track, you may find a pocket compass a deliverance from a very comfortless night.

It was nearly twenty years since I had been in these hills, and they, or rather I should say, all the details of them, were as good as new to me. I noticed with curiosity how these details gradually came back to me as things known in a previous state of existence, bringing the old associations back with them, so that I lived in a fresh undergraduatehood once more. Again and again their original writing on my mind had been written over, in other regions and other climates, and yet by some mysterious process it was brought to light, and the palimpsest made intelligible. In ascending one hill through a wood, I could not be sure that I was on the old familiar path till certain mossy rocks, jutting out into the path under the ash-trees, came home to me like old friends-not suddenly, but with a growing consciousness of certainty that became firmer every minute. I sat down a while by those old rocks to let them have their way with me.

In those days I knew nothing of birds; I was far 
too much engrossed in Aristotle and fishing to find room for natural history. Now, wherever I go, I find something new to learn, for birds are everywhere; and in this very spot I had a note to make that was of great interest to me. In the Alps I have noticed that the song of the Tree-pipit is heard in all the lower timbered pastures up to the point at which the pines come to an end, and the real alps begin. To that point you must ascend if you would hear the true Alpine Pipit, which there takes the place of the other, singing perhaps a more monotonous song but one quite as blithe and cheering, as it hovers in the air out of sight, then slowly nears you, to drop on to a boulder or a tuft of alpine rhododendron. During my short climb up the Welsh hill-side I had heard the Tree-pipit continually, and when I reached the margin of the wood and came out on those delicious gentler slopes, where only a tree here and there breaks the welcome sky-line, the same bird was still singing vigorously; but as soon as I had left these straggling trees behind me, and was fairly out on the open moorland of sweet short grass and thick dry ling, then I was saluted by the voice, not of the alpine bird, but of our own English Meadow-pipit, which descends in autumn, like its alpine cousin, to lower feeding grounds, and is known in fact to all of us, at all seasons, as the Titlark. For a moment I was fairly carried off to those exquisite alps above 
Engelberg, with which I especially associate the alpine bird; for the songs of the two are much alike, though the foreigner is bolder and stronger in his flight, and louder and more continuous in his strain. He and his song are in keeping with the huge reach of the rocks and peaks around him; the height and range of his flight are great, and you often search for him in vain, as the bell-like notes come now from this side, now from that, or lose him, after once catching sight of him against the sky, as he descends to the ground in the shadow of some dark precipice. But the English bird soon catches your eye, and hovers near you if you are likely to approach its nest; no mystery attends it, no great mountain walls encompass it, nor does it mount far away in air and "despise the earth," like the Skylark that was singing there too, away from all human cultivation, a tiny speck against the light driving clouds.

There is a valley in this district, stretching far away into the wildest moorland, of which the alpine character is quite unmistakable. The hills rise steeply from the swiftly-flowing river, and are in many places clothed with dense plantations of pine and larch; above these again you come out on yet steeper slopes of grass and fern, with gray silurian rock jutting out in regular lines, or sometimes forming precipices intersected by damp mossy gullies, 
difficult indeed to climb, but leading to that invigorating level moorland where the Pipits have their summer home. On such a craggy edge a friend of mine, returning last Whitsuntide from a ramble through drizzling Welsh rain, came suddenly upon an Alpine Accentor. He had known the bird in Switzerland, and his account of it leaves no doubt in my mind as to the identification. It was sitting in dumpy fashion on the edge of a rock, as this Accentor loves to sit, and the chestnut of its flanks and the double whitish stripe on the wing were distinctly visible to the astonished stranger.

Four weeks later, inspired by a faint hope of finding this bird breeding for the first time in our island, Mr. Aplin and I made a rapid journey to the same district, and were guided to the identical spot by the most explicit directions from our friend. For two mornings we scrambled about those rocky slopes, and noted how singularly they resembled the Accentor's haunts on the Joch pass; but our search was all in vain. This bird alone was wanting to complete the illusion that we were in the Alps. The Ring-ousel was nesting not far off, and we could now and then hear his metallic alarm-note from some stunted bush among the crags. Here too was of course the Wheatear, singing that delicate warble which is so grateful to the ear of the dweller in midland plains; and here too were a few pairs of 
Redstarts, reminding us of those darker cousins of theirs which welcome us to the highest alpine pastures.

What Englishman would naturally think of our little Redstart as a bird of the mountains? We associate him in Oxfordshire, where he abounds in ever-increasing numbers, with the thick hedgerow, the pollards by the lazy stream, the old wall in the garden, the chequered shade of the orchard. Yet his tastes seem to be almost as cosmopolitan as those of his continental cousin,-modified, I should perhaps add, with some slight tincture of caprice. It is most strange that in the south-east of England he should be comparatively uncommon. Ten days of constant walking in Kent showed me hardly a single pair, and confirmed all that had been told me by residents in that county and Sussex. Those enthusiasts who, loving the birds more than justice or knowledge, would ascribe the scanty numbers of some species in those counties to the cruelty of mankind, will be utterly unable to convince me of this in the case of the Redstart. It cannot be truly said that this bird is persecuted anywhere; and if we are to try and explain why it should prefer the west to the east, I should be inclined to guess that the waterless downs and heaths do not suit its needs so well as damp river-valleys and moist mountain sides. The Redstart loves the pollard willows that line our 
midland streams, and all places where good nestingholes, and abundant insect food, and plentiful water can be found; and no one who is used to see him daily and hourly in such places would expect to find him in equal plenty in a drier climate.

But to return to the Welsh hills. Here in June it is still spring; such hedges as there are here are still white with hawthorn blossom, and the wild roses have hardly begun to bloom. The grass even here in the valley is short enough for me: a short, thick undergrowth of flowers, with enough of taller grasses to suggest that it is meant for hay. But about these fields, and round the fine solid new church, which stands at the junction of two mountain streams, the Sand-martins are busy, reminding me of the richer water-meadows I have left behind me in England. The Sand-martins took me by surprise: in old days I never noticed them, and never learnt to associate them with water that talks as it runs. About Oxford, where they are perhaps in greater numbers than in any other haunt of mine, their conversation is unbroken by the noise of water; and in the silence of a still summer evening it forces itself on your attention, for there is nothing but your own thoughts to rival it. Here, as I stood in the churchyard, with the streams and the Sand-martins chatting all around me, there seemed to be much more life and stir than by the silent Thames in the 
heavy English air. Probably this was the last colony on this side of the mountain range which separated me from the Irish Sea : the last ripple of the wave of Sand-martins which comes surging in April up the larger rivers, breaking into lesser parties, we may suppose, to seek old haunts up the smaller streams, and so touching with one of its last laps this faraway mountain hamlet. Inque sinus scindit sese unda reductos! ${ }^{1}$

In my last chapter I said that in the Alps we hardly see so many birds of prey as we should expect in such a region; and in this one respect at least the Welsh hills are the better hunting-ground. I write, indeed, with hesitation on such a subject, and name no names of hill or valley; for so long as the fury of the egg-collector is unabated, so long will all birds of prey be in danger-in danger far greater than that to which they expose themselves by their own cruelties. The young lambs may be harried every spring, and the game in the larch covers may attract the enemy, but still that enemy survives all vengeance of the angry farmer and disgusted sports-

1 Yet some at least of these birds arrive in Wales very early. They were seen this year both in Glamorganshire and Pembrokeshire during the first week of April ; while at Oxford none were seen till toward the end of the month. These early arrivals probably come from the Continent by way of Devon : $c f$. Mr. Murray Mathew's Birds of Devon, p. 59. The Sand-martin's lines of migration need further investigation. 
man. I have known this district for thirty years, and as far as I can see the great birds are as abundant as ever; but when once the egg-dealer has found them out (and that he has found them out here I know too well), it can only be a question of time. These hills are not such as afford them many nesting-places that are utterly inaccessible; and when their strongholds have been stormed year by year for a while they will give up the game and die or depart.

But as yet the process of extermination has not gone nearly as far as the lamentations of Mr. Hudson would lead us to suppose. ${ }^{1}$ In 1869, when I spent some weeks in one of these valleys, the cry of the Buzzards was the daily accompaniment to our studies of Aristotle and Livy. In 1894, a few miles from the same spot, it was still possible to lie on the crest of a hill and watch two, three, or even four of these noble birds soaring overhead at the same time. Ravens I do not remember in the old days, but of ornithology I then knew nothing. In the spring of the present year they were numerous, and many a sickly lamb on the mountains had his young eyes hacked out by those terrible bills of theirs. ${ }^{2}$ While

${ }^{1}$ See his pamphlet issued by the Society for the Protection of Birds, entitled Lost British Birds; the value of which I readily acknowledge, irritating as it is in some ways to those who have lived all their lives in England.

2 That this is often the case I was assured by the farmer with whom I lodged last spring in this district. 
scanning the unclouded blue for even grander birds than these, I once caught myself saying, as a black speck over the opposite hill began to near us, "It's only a Raven!" And this in spite of all the farmer's temptations to destroy this cruel enemy of his. The Raven will not easily be extirpated; there are still English counties as well as Welsh ones in which he may be hopefully looked for, and if the passion for private egg-collecting can be only kept within due bounds, there need be no fear that he will disappear from our British list.

But what were those still grander birds for which we augurs were watching the heavens in the last days of March this year? I have a record, in a diary kept among these hills in 1869, of the appearance of a Kite for two successive days; and since then, though always expected to die out, these comparatively harmless hermits have contrived to maintain themselves here, as the pages of the Zoologist will testify. This year, almost in the same spot where I first saw them a quarter of a century ago, I once more watched their magnificent flight with wondering eyes. Few Englishmen have had that experience, and some may care to read the note I made. "We soon saw a Kite above us, at first quite near; the sun lit up the red colour of his back and tail, and (as he turned) the rusty feathers of his under parts. The wings were narrow, with the 
58 Summer Studies of Birds and Books cHap.

primaries standing out distinct from each other like a Crow's ; the tail long, the 'fork' most distinct-as if a deep segment of a circle had been cut out of it. $\mathrm{N}$ — was just saying that this might be the last survivor of the race, when a second bird appeared rising from the wood to our left, and then soared just over our heads, giving us a splendid view. The two then circled in a slow upward flight: the wings beaten eight to twelve times in succession, with a curving motion of the wing, then a graceful glide round half or more of the circle. At last they became mere specks in the blue, and we could hardly keep them in view even with a strong field-glass."

These splendid birds were then engaged upon a nest in a place very far indeed from being inaccessible. I need not say that we left that nest wholly undisturbed, and that we bound ourselves to betray the secret of the spot to no one. Yet when next I had news of the district the harpies had descended upon it:

"Nec saevior ulla

Pestis et ira deum Stygiis sese extulit undis."

Whether they robbed the Kites' nest I know not, but they wrought other havoc. From what I saw two months later I am inclined to hope that the Kites retreated to a position from which even an egg-dealer would have found it hard to dislodge them, and that 
their life last breeding season may after all have been a happy one. But let me insist on it once more that, though they may escape the farmer and the sportsman, neither of whom is in those parts wantonly vindictive, they cannot long survive the greed of the trader in eggs; and further, that the trader himself can only be suppressed by a rigid self-denying ordinance on the part of the private collector. ${ }^{1}$

But we must leave the rocky summits of the hills, and descend, perhaps through very steep woodland, to the winding valley with its road and river. In some places the hills are clad almost to the very crown with trees ; and not only with pine or larch, but here and there with oaks of no great height, with a border of ashes or sycamores on their last gentler mossy slopes by the river. Beneath the trees is no great luxuriance of grass, for the brake-fern here has it all its own way, and covers the whole hill-side, except where an occasional bit of rock juts out, in the shelves and crannies of which a mossy turf is spread. Could any place be a more pleasant and beautiful home for wood-loving birds? I have often noticed that a steep slope, where trees are not too closely packed for the sun to shine freely in among the shadows, is always a favourite haunt. Was there not, and is there not, the famous Hanger of Selborne, made memorable for ever to English bird-lovers? Another

1 See Mr. Salter's note in the Zoologist for August 1893. 
such steep wood in the chalk country has been admirably described by the late Mr. Jefferies in the Gamekeeper at Home. They are good for birdobservers as well as for birds, for there is no position so happy as one from which you can look down, unobserved, through a vista of trees, without wearying the eyes by a long, strained, upward search through tangled foliage. Taking up your position at some point where you can command as many trees as possible, leaving the upper and denser foliage for the most part out of your thoughts, but keeping a keen eye on all barer boughs or leafless twigs-for these are specially affected by some birds, and others too will come to them in the course of their wanderings, -you may sit quietly down and wait, with binocular ready, and ear as keenly observant as your eye would be if it were watching your flies on the stream far below. In such moments the sharp look-out you have to keep will in no way hinder you from enjoying the beauty of the interlacing oak-branches, or the gray tint which the lichen that everywhere clings to them gives to the whole woodland scene.

The ear will probably be the first watchman to give the signal for a still closer attention. The voices of the ubiquitous Chaffinch and Willow-wren have not been enough to rouse it, for they are at hand everywhere, both in Wales and England. But now I hear the voice of a little bird that is not too 
common to be invariably attractive and interesting; it is not unlike the winding-up of an oldfashioned watch or a musical box, if you imagine the key turned very slowly at first, then more and more quickly, until the position of the winder's hand compels him to rest for a moment and begin the operation afresh. Once more we are reminded of the Alps ; for this is the bird which is so nearly related to Bonelli's Warbler, and so like that little friend of mine in habits, appearance, and voice. A most curious voice is his, and though not strictly musical, very far from unpleasing to the ear; the silvery "shivering" quality of it which White noticed long ago has a way of craving your attention, and growing upon you as it comes nearer and nearer. Patience is necessary if we would see the bird fairly; and the only way is to sit and wait till you have caught him, even but for an instant, with your unassisted eye, and marked the tree in which he is searching for food. He will not wander far, unless you pursue him; the nest is in the fern not far away, and the persistence of his note makes it probable that his wife is still sitting on eggs, and that the duty of finding food for hungry young has not yet begun. Watch him till he comes near enough to show you how all a bird's mind is put into his song; as he utters it his long, closed wings are slightly opened and shaken, and his bill opens wider and wider, 
till the vibrating tongue is clearly visible as the head is held upwards to sustain the effort. Every now and then he will communicate with his wife by a signal she knows well : it is a series of long, pathetic notes, which can be heard at a long distance, and speak his tender love and appreciation of her labours. These notes are uttered - for I have watched the bird at a distance of a few feetwith the bill almost closed, and with no sign of effort; they are rather an inward meditation than an outspoken call, in spite of their resonance.

What you see when the Wood-wren has revealed himself is nothing but a little brown bird with a whitish-yellow throat and pure white breast and belly; the books indeed tell you that there is much yellow about it, but this you would readily discover only if you had it in your hand and could turn up the feathers. But if not conspicuous in his colouring, he is a model of perfect grace in shape and movement; and if birds are to be studied, as indeed I hope they are, not merely as empty skins, but as living creatures with minds, hoping and fearing, rejoicing and sorrowing, here is one that I may well watch for half an hour, and feel as much indebted to the sight of his delicate form and harmonious motion as I should to the contemplation of the gracefullest of Greek vases or the purest melody of Mozart.

There is one other bird which I should wish to 
notice before I leave these woods and close these notes for the present, which does not need to be watched for like the Wood-wren, but obtrudes himself upon your attention by his bright plumage, his comparatively loud note of warning, and his preference for the lower and barer boughs of the trees. It is not often that we of the midlands have the chance of seeing or hearing a Pied Flycatcher. When he does appear, he is only a passing visitor on his way to the hills, and I have never known him stay with us more than one day. Yet it is well to keep a look-out for him in the valleys of the Thames and its affluents during the latter half of April; and his plumage is just then so brilliant that it cannot fail to catch the eye. The white of the breast is so pure that in the sunshine it will be distinctly visible at a great distance, and can be distinguished at once from the grayer tint of the same parts in the commoner species. I have on two or three occasions come upon a pair travelling together in Oxfordshire, or rather resting from their travel; they perch on a railing and spend the day in catching flies with such an air of contentment and savoir faire that you are deluded into fancying that they are going to remain your guests; but the next day you will look for them in vain.

It would seem that the flat country is not to the mind of this bird, and he quickly leaves our gardens 


\section{Summer Studies of Birds and Books cHap.}

and orchards to the Spotted Flycatchers who are following him from the Continent, and makes north and west for wooded hills and dales. And this is not because he is persecuted, or likely to be, for his nest is not easy to find, nor yet easy to plunder when found ; but simply because one of those predilections for which we can never entirely account urges him towards sunny timbered slopes where the trees are old and offer him a choice of many a cavernous homestead. From the Lake Country we have excellent accounts of him in the well-known books of the Rev. H. A. Macpherson; but perhaps his favourite homes are the central hills of Wales. Even here, however, he is somewhat capricious ; while in Breconshire and Radnorshire he is quite a common bird, I have never once found him in the Glamorganshire hills, which I have known almost all my life. On the Continent I have always seen him in just such places as he loves in Wales, among the larger timber of a Swiss mountain-side, or on the forest slopes of the Taunus range. ${ }^{1}$ Just as the trout loves swiftlyrunning streams, or as the Wood-wren is sure to be heard where the oak is the prevailing tree, so there are certain spots which you instinctively feel that

1 Once or twice I have seen it in the garden of a hotel in Switzerland, and once nesting in a tree on the outskirts of Interlaken. For the distribution of this bird in Wales see Zoologist for November 1893. It is singular that we hear so little of it from the border counties. 
this bird ought to have chosen for his habitation, and if you are in the right district you may fairly lay a wager that he will be found there.

Such a spot, on the edge of the beech forests of Wiesbaden, will always remain in very clear outline in my memory, for it was there I first heard the song of this bird. It is very seldom now that I hear a song that is quite new to me. If it were not that so many of our songsters sing all too short a time, and that when they tune up one by one for the orchestra of the spring season each instrument touches the ear with the fresh delight of recognition, I might feel as much at the end of my tether as the mountaineer who has no more peaks to climb. But this song was not only new, but wonderfully sweet and striking. "Something like a Redstart's," say the books, and this is not untrue, so far as it represents the outward form, so to speak, of the song-the quickness or shortness of notes, the rapid variations of pitch. But no one who has once accustomed his ear to the very peculiar timbre of the voice of either kind of Redstart will mistake for it the song of the Pied Flycatcher. My notes, taken on the spot, and before I had seen any other description of it, recall the song to my memory - the short notes at the beginning, the rather fragmentary and hesitating character of the strain, and the little coda or finish, which reminded me of the Chaffinch; but all this will have no meaning to 
my readers. There is but one way of learning a bird's song, and that is by listening to it in solitude again and again, until you have associated it in your mind with the form and habits and haunts of the singer.

The Pied Flycatcher may, under certain circumstances, be a puzzling bird to the novice. An old male, in full plumage of black and white, is indeed unmistakable; but the female, the young, and (as is now well known) some at least of the birds of a year old, have the back and head of a grayish brown. The pair which I watched at Wiesbaden were very much alike, and as they were flitting about the highest branches of an old gnarled oak, I had some trouble in identifying them even with the field-glass. I knew little of the species then, and the brown in both sexes puzzled me, the song puzzled me, and when the male showed his tail to me delightfully while clinging Swift-like to the mouth of the hole they were choosing for their nesting-place, the white of the two outer tail-feathers puzzled me no less. ${ }^{1}$ Worst of all, the brown of the head was distinctly reddish, and it was not for some time that I discovered that this was caused by the sunlight falling on the bird and reflected through the ruddy young oak-leaves that brilliant April morning. Only the

1 For the brown of the back in breeding birds, $c f$. Macpherson's Birds of Cumberland, p. 36. 
manner of the/birds and the peculiar pose of their heads kept me pretty steadily to the conviction that I had Flycatchers before me.

A few years ago it was hardly known that this beautiful bird is so regular a visitor to many parts of Wales; but recently some attention has been paid to Welsh birds, and good ornithologists are at work there. Much, however, remains to be done, and we can but hope that it will be done without letting in the harpies to spoil with their noisome feasts the secluded homes of the Pied Flycatcher and the Woodlark. The Birds of Wales, when such a book is written, will greatly exceed in interest the monographs of the ornithology of single English counties, if only because Wales is a natural division of this island and not merely an artificial one. Such a work will have to be one of slow growth, and must be the result of organised combination and division of labour. But I should not be surprised, were I to live long enough to see it completed, to find that some remarkable discoveries had been made among those wilder hills which the tourist has not found out, and where the smaller birds are despised or overlooked by the sportsman.

For myself, I confess that when I find myself among these hills the evil propensities of former days are apt to get the better of me, and by a deep dark pool, well ruffled by the mountain breeze, I 
almost cease to hear the note of the Wood-wren coming towards me through the lichened oak-boughs, while I extract one little trout after another from the peaty water. I could almost wish that, like these Wood-wrens, the trout had a voice to express his hopes and fears; if that were so, I think my fishing career would once more be a thing of the past. It may be that one reason at least why of all sports fishing is the only one that pleases me is because a fish is a silent animal. You haul him from his element-he complains not but by gesture; you put a speedy end to his existence by a sharp knock-he leaves his life indignant but in silence. There is a certain tarn among these hills where the trout are said, when caught, to give vent to their indignation in inarticulate sounds; but I have never fished in that pool, nor, if I found the story true, would I fish there a second time. 


\section{CHAPTER IV}

THE MARSH WARBLER IN OXFORDSHIRE AND SWITZERLAND $^{1}$

EVERY one who is fond of reading books of travel in the tropics must know what it is to long for an hour or two of real life in a virgin forest, or in the boundless expanse of the pampas, or even in the depths of a mangrove swamp. We would willingly put up with mosquitoes and "piums" and poisonous ants, if we could but see that world for ourselves which Darwin and Bates and Wallace and Belt have made almost, but not quite, a reality for us. Charles Kingsley had this ambition all his life, and was able in the end to indulge it. His enthusiastic delight at what he saw in the West Indies made him even more than usually eloquent, and his chapter on the "High Woods" marks perhaps the highest point

1 A paper read to the Oxfordshire Natural History Society, November 1893. 
which a traveller's descriptive power can reach. Let me quote a few words :-

"For the first moment the forest seems more open than an English wood. But try to walk through it, and ten steps undeceive you. You look up and around; and then you find that the air is full of wires,-that you are hung up in a network of fine branches belonging to half-a-dozen different sorts of young trees, and intertwined with as many different species of slender creepers. You thought at your first glance among the tree-stems that you were looking through open air; you find that you are looking through a labyrinth of wire rigging, and must use the cutlass right and left at every five steps."

And so on for whole pages of masterly description, dictated by an almost childlike astonishment at finding the expectations of a lifetime so entirely outdone by the reality.

Few of us can look forward to the enjoyment of these uncomfortable delights, except in reading and re-reading the old familiar books. Yet I think that these last two summers I have tasted them for a few short hours; a very faint flavour of them it was-a bare suspicion of distant resemblance ; and this was in England, and within half a mile of my own home in this county. If you would gain some dim notion of what tropical vegetation is, try a neglected 
osier-bed on a hot day in June. The willows must be nearly twice as tall as you are yourself, planted together in rows, with a drain or ditch between each row ; and they must be covered with a thick foliage of monotonous light green,- just enough to let the hot sun through. These osiers should also be full of flies and midges,- - the one settling on your nose, and the other biting your ears, at every moment when you least desire such interruption. Their stems, for three or four feet or more, should be hidden in an undergrowth of long, dry, wiry grass, so thick that it is hard to push through it, with heavily-odorous meadowsweet just coming into bloom, and with that peculiar zigzag-growing tangle of a plant which leaves its seed-vessels sticking on you whenever you touch it. The ditches between each row should be just wet enough with recent showers to give your feet a cold bath if you plunge into them unawares; and they should be just so carefully hidden by the long dense grass as to lead you to forget again and again that there is water beneath it. Choose an osier bed of this pattern, and spend an hour or two in it, with some eager purpose in your mind which will not let you leave it, and you may at last feel that you know something of what a mangrove swamp is like, or what it is to try and force your way through the tangle of an American forest.

But what led me to expose myself to these petty 
discomforts? I had no wish to prowl about in this osier-bed merely to see what it was like; and indeed it was not so very easy to get into, for it was fenced with barbed wire on two sides, and on the other the only entrance was through a thick overgrown hedge, with a wet ditch on the further side. The fact was that I went to see and hear a certain small brown bird, and, if possible, to find its nest; and thereby hangs a somewhat lengthy tale, which must be told, if you have the patience for it, before I lead you into the labyrinthine recesses of the jungle.

It is on the 18th of May 1888 that my tale begins - a day when the academic precincts of Oxford were unusually quiet and deserted, owing to a cricket match with the Australians. I was entering the Botanic Garden that afternoon, when I heard in a bush, just outside the turnstile, the song of a Reed Warbler. This was no new thing, for the bird is quite common all round Oxford in suitable places; but what struck me most was, first, that this was not a suitable place, and, secondly, that the song was peculiar for a Reed Warbler. The bush was just inside a hedge of privet, and there was an apple-tree overhanging it : exactly opposite are the schools of the parish, outside which, at various times in the day, there is the usual shouting and screaming of boys and girls let loose. Now, our 
Reed Warblers, it is true, have long ago adapted themselves to circumstances, and often build, not in reeds, but in bushes,-in privet, lilac, willow, etc. : using the pliable twigs exactly as they used to use the reeds, i.e. gathering them into the nest in order to secure it more strongly against wind and storm. There was no reason, then, why a Reed Warbler should not choose the privet hedge for an abode; but for so retiring a bird to select a spot within a few paces of a school was surely singular. And then the song, which was almost incessant, was also loud, vigorous, and delightful: if it were really the song of a Reed Warbler, the singer had a marvellous gift, far exceeding that of any individual of the species that I had ever yet heard. The Reed Warbler's song is unusually quiet and sedate, and even monotonous; but here was a bird of genius, who understood how to turn the ordinary song into a very brilliant and diversified performance. I saw the bird once or - twice for a moment, and it appeared to me to be quite indistinguishable from the Reed Warbler; I doubt if it then occurred to me that it could be anything else. The next day it was gone:

Next year (1889), on 8th May, I again heard this wonderful outpouring of song in the same place; and by this time it had occurred to me that the singer might be the rarer Marsh Warbler, which has only of late years been fully recognised as an English 
bird. The books did not give me much hope of distinguishing the two by external appearance; but they all agreed that the song of the Marsh Warbler is far finer, sweeter, and more varied than that of the Reed Warbler. Now, this bird again sang with such force that even the gardeners in the Botanic Garden had been struck with it; and I determined to do all I could to solve the mystery. I hid myself inside the privet hedge while the children were safe in school, and spent a long time in scrutinising the bird and his song, while the murmur of lessons went on outside, and walkers and talkers passed up and down within a yard or two, neither seeing me, nor noticing the song. I continued to pass stray halfhours here for a day or two, until again the bird departed; not frightened, I think, by the silent human figure that kept lurking beneath the bush, but finding the place too lively at times for him to hear his own voice in comfort.

The result of my perseverance was practically nil. I had never heard or seen an undoubted Marsh Warbler, and I could not have attested in a court of justice my conviction that this was a bird of that species. This is a misfortune which must often befall the ornithologist, who cannot seize on a bird as a botanist gathers a plant; even if he has a gun in his hand he is probably most unwilling to use it, and in the public places of a town he fortunately 
cannot use it under any circumstances. He may feel as sure as he can be that he has seen something remarkable, yet he may very well fail to convince a truly discreet brother of the craft. Many a good record has doubtless been lost in this way, but, what is much more important, many a bad record has been set aside. In this case, however, I could not even feel any moral certainty; to an inexperienced eye the two species are almost exactly alike, and I had yet to learn what it is that really separates them beyond a doubt. All this was very tantalising, but luckily for me there was a way out of the difficulty. In another month I should be set free from my Oxford work; what pleasanter plan could I make for a holiday than to go and search for the real Marsh Warbler where I knew he was likely to be found? Could I but pay him a visit in his Continental haunts, I might be pretty sure in a day or two of fixing his identity in my mind beyond all doubt and dispute.

I knew where to go; for Professor Fatio of Geneva had studied the bird in a certain Alpine valley which is evidently a favourite haunt of the species, and this valley I might easily reach before the nesting and singing came to an end. But first I determined to go to Meiringen in the Oberland, in order to pick up my faithful old friend Johann Anderegg, whose knowledge of Alpine birds had 
been so often useful to me; and to Meiringen accordingly I went with all speed as soon as my duties came to an end. I did not need to go any further to find my bird. The very morning after I arrived there I was strolling along a path which runs between allotments towards the famous defile of the river Aar, when I heard a very sweet and varied song which instantly attracted my attention. I soon discovered the singer, perched on a tall pole which had once supported peas or beans: he was within about thirty yards of the river, and behind him was a hedge, behind that again a deep hollow filled with reeds and bushy undergrowth, then the embankment of the Aar, and finally that great glacier stream itself. To this promising spot I betook myself at once, in order to find out who was the singer of a song so new to me and at the same time so sweet. After spending some time here, I felt pretty sure that this was the bird I had come to seek, and I also felt sure that the bird of the Botanic Garden was not the same as this. The song of this little fellow was of an entirely different type; instead of being a brilliant edition of the Reed Warbler's song, it never once reminded me of it. It was something quite new to me. I did not on that occasion hear the full performance, nor did I then discover the extraordinary power of mockery which the bird possesses ; but within a day or two I became aware 
of this, and have something to say of it later on. For the present I will only add that not only the outward appearance of the bird, but more especially his attitude in singing, his sprightly and restless habit, and above all the unique character of his infinitely varied song,-in all of which characteristics he agreed with all the descriptions of the Marsh Warbler I had ever read,-convinced me that I had here the bird I was looking for,-and so indeed it turned out. I did not find his nest that year, which would have made certainty doubly certain; but I returned to England knowing that I could never again have any real doubt about the essential difference between Reed Warbler and Marsh Warbler, and pretty confident that I should be able to tell them apart in future, if at any rate they would but oblige me with the sound of their voices.

But two years were to pass before I was to see my little friend again. That wonderful singer never came again to the Botanic Garden; and if he was really a Marsh Warbler with an eccentric song, his identity can never be proved. It was not till the summer of 1891 that I was again able to visit the Alps in the breeding season; but when that pleasant opportunity at last arrived, it brought with it a complete solution of all my difficulties. Luckily I had engaged as my travelling companion my friend Mr. O. V. Aplin, who had recently inserted 
in his Birds of Oxfordshire a note of mine about the bird of the Botanic Garden. I was to find out the localities in which we were likely to come upon new - or interesting birds, and my friend was to bring his accurate scholarship to bear upon them when found. I use this word scholarship intentionally, for there is no other that so exactly expresses that combination of knowledge and observation,- - of observation strengthened and controlled by knowledge, and of knowledge based on observation and only aided by books, - which is characteristic of every true naturalist, as of every true scholar. There are many inaccurate naturalists, as there are many inaccurate scholars; and as I know myself to be by nature inexact, I am most unwilling to accept the evidence of my own senses without some confirmation from those of a better scholar.

On the second day after we reached Switzerland we spent two or three hours at Interlaken, where we found much to interest us. At the end of the long street which leads towards the Lake of Brienz we passed out into a spongy-looking and reedy tract, lying between the river Aar and some cultivated ground,-just in the same position as the haunt of the Marsh Warbler at Meiringen. Here I proposed that we should follow a footpath which ran along the river-side, and seemed likely to lead us to some bits of scrub and wild ground which we could see 
about a quarter of a mile ahead. This scrub turned out to consist of some kind of low-growing willow, with ditches and hollows overgrown with long grass and meadowsweet. My friend plunged into it, while I went on a little further. Almost directly he called me back, and by the waving of his umbrella I saw that he had made some discovery. It was indeed a discovery; it was the nest of a Marsh Warbler. There was the nest, and there too was the bird, which continued to creep about the neighbourhood of the nest for some minutes after we had disturbed her. There were four eggs in the nest, the beauty of which will always dwell in my memory. They were of the same type as the Reed Warbler's, but instead of being densely covered with greenish spots, their ground colour was greenish white, with many largish dull purple blotches, gathered chiefly at the thicker end. The nest too was specifically distinct from that of our familiar Oxford bird; it was of a slighter make, and not so deep, but the stalks of the meadowsweet had been drawn into its structure, much as the reeds or the shoots of privet or lilac are used in the nest of the Reed Warbler. It is worth noting that the few nests of this species which have been so far found in England have been usually suspended in meadowsweet; and also that they have never, so far as I know, been found immediately over water, but at a little distance from it, and not very far from culti- 
vated ground. We took one egg only, and after some further search returned to the village, and went on our way to Meiringen, where we were to sleep that night.

Next morning I went to the spot where I had first heard my bird two years before. There is always a pleasing excitement in revisiting such a spot, just as there is when you call unexpected at the house of an old friend and wonder whether you will find him at home. Has he left the old place, or will he start up from his chair to welcome you with that brightness of the eye which sudden and genuine pleasure always charms into being? Ornithologists know how homeloving the birds are, and especially the various little "Warblers" as we call them; rarely do they disappoint us year after year, when we wait on them in their accustomed haunts as May comes round. It matters little whether they are the same individuals who entertained us before; at any rate, like trout, the little things take care that some one shall be there to welcome us, and the "living" in the reed-bed or willow is seldom vacant long.

My old friend of the allotments by the Aar was at home that morning (19th June), and treated me to a very delicious and amusing concert,-missed unluckily by my companion, who had been unwell and unable to join me. "I am now writing," says my diary of that day, "in a cool spot between the allotments and 
the Aar, and listening to the Marsh Warbler, whose song is as wonderful as ever. Sometimes a grating outburst like that of a Sedge Warbler; sometimes a long-drawn sweet note like a Nightingale's. Then I have within the last few minutes certainly heard the Chaffinch imitated, and even the Nuthatch's metallic note. But a low pleasing soliloquy also goes on at intervals. Ah ! there is the Great Tit; now the White Wagtail, and I am beginning to get bewildered. This bird creeps about a good deal in the bushes, but now and then appears on a topmost shoot, and sits there singing with his bill wide open, and a red-yellow 'gape' showing very plainly. Now and then he flies into the tree over my head,-ah! there is the call of the Redstart, and surely this is the Skylark's song; and there is the Chaffinch again, if ever I heard a Chaffinch."

When Aplin was able to bestir himself we strolled again to this spot : but the bird was silent, or almost so. And for those who may seek his acquaintance it may be as well to say here that the Marsh Warbler is essentially a morning singer. I do not say that under favourable conditions he will not sing all day long, like the Nightingale, nor do I mean to exclude the possibility of his singing at night. But within my own experience, both in England and abroad, he has always been at his best from six till ten in the morning. It is then that he will take his post on 
some coign of vantage, and indulge in his faculty of mimicry,-meditating his song, as it were,- "What shall I try next?" Later in the day he seems more restless, and flies further afield; while in the earlier hours he sings as a rule so close to the nest that it is then often quite easy to find.

And thus indeed it was that a few days later (27th June) we found a beautiful nest in a place which I would recommend to every one who would make acquaintance with this delightful bird. We had crossed the mountains from Meiringen to Engelberg, spending on our way three most profitable days at the Engstlen Alp, the favourite summer home of many interesting species; and from Engelberg we descended to the Lake of Lucerne at Stanzstadt, which stands on that arm of the lake from which Pilatus rises precipitously. Just outside this village is a long tract of reedy ground, such as in the north of England they would call a moss, quaking somewhat as you walk on it, but really quite safe and dry, except at the margin of the lake, where it imperceptibly slips into shallow water. This tract shows here and there large bunches of meadowsweet and other tall plants, and among these you will never fail in June to hear the bird you look for. In such a little thicket of meadowsweet, at about eight o'clock in the morning, we that day heard a splendid singer; and after listening for a few minutes while he sang 
away a dozen yards from the cart-track on which we stood, I made my way through the undergrowth, and came upon the nest just where the bird had been singing. It was of grass, with a very few hairs in the lining, and contained two eggs somewhat whiter in tone than those we found at Interlaken, and spotted only at the thicker end. We found no other nests that day, but heard much singing; and we noted that, in spite of the many imitations in which the bird indulges, there is always a very sweet silvery individuality about the song, which makes it quite unmistakable, and should distinguish it for every reasonably acute ear from the Reed Warbler's quiet soliloquy, or the rattling enthusiasm of the Sedge Warbler. The former of these two cousins may be heard sometimes in this same moss, but always among the tall reeds by the water: the latter, so far as I know, is a stranger to these parts, nor do I remember ever to have heard or seen it alive in Switzerland.

The individuality of the Marsh Warbler's strain must have impressed itself very keenly on my memory. And it was fortunate that this was so, for in spite of minute differences of colouring between this bird and the Reed Warbler,-of which I shall have a word to say presently,- - the two are in truth so much alike that if they were silent birds it would be as hard to distinguish them when alive and free 
as it is when they are presented to you in the miserable condition of "skins." Nearly a year after we had left Switzerland, after the gloomiest of winters, made doubly triste by the last epidemic of influenza, my ears were once more gladdened by the strain I had learnt to love, - and this in England, and within ten minutes' walk of my own house in Oxfordshire. To this snug corner of the midlands, and to that osier-bed whose delights I began by recording, I must now ask you once more to accompany me.

I was returning from a stroll on Whitsunday, 5th June 1892, and was just turning the corner of this overgrown wilderness of willows, when I was suddenly pulled up by a fragment of song, undecided, imperfect, yet of so sweet and silvery a tone that neither Reed nor Sedge Warbler could have uttered it. Such moments are never to be forgotten by those who have ever felt the spell of a wild bird's voice. There is an inward conviction in the hearer's mind that overpowers all transient troubles, and banishes utterly all thoughts of work and books; and with it there is the not unpleasing phantom of a doubt-a piquant spice of uncertainty-not so much about your own conclusion as to the bird's identity, but as to the chance of getting others to accept it. And on this occasion, wait as long as I would, I could obtain no glimpse of the singer; nor was he inclined 
to sing a full and utterly unmistakable melody, for the day was well advanced. That night I had to leave for Oxford, and it was not till the following Thursday that I could leave my duties there for a few hours, and attempt to put the evidence of my ears to the test.

On that day I penetrated alone into the osiers at 8 A.M. The morning was very hot, and I soon began to find the conditions of my search uncomfortably tropical, for not a breath of air could reach me, and this particular spot happens to be one of the warmest in the parish. But all such discomforts cease to tease the instant the mind has something to work on ; and in a very few minutes I knew that my conviction of last Sunday was no delusion. At intervals during two hours I listened to as wonderful a display of mimicry as I had heard at Meiringen or Stanzstadt. This bird completely deceived me once with the song of the Tree-pipit, and constantly fell to mimicking the Lark, the Swallow, and others; and though I could only get a momentary glimpse of him owing to the height of the osiers, I knew him for the Marsh Warbler as certainly as if I had caught him in my hand. It was not only the mimicry that made me sure of him, for a lively Sedge Warbler will of course sometimes indulge his fancy in this way: it was the sweet clear tone of the voice, with its rapid changes, its sudden stoppages, and its comparatively 
rare lapses into sounds that could be called grating or sibilant.

The next thing to be done was to procure witnesses and to find the nest; for my own evidence alone would fail to convince the scientific ornithologist. I summoned three competent witnesses in the course of the next three weeks, and though our united labours never revealed the nest, the conviction of each observer became in each case as decided as my own, and constituted a case too strong for even the hardest-hearted sceptic. The first was a young enthusiast from Oxford, who knew well the songs of all our common Warblers. I let him listen for half an hour alone, and when I joined him I found him thoroughly convinced that he had never heard this song before. The next was Mr. Aplin, who had not been in the osiers ten minutes before he declared himself fully satisfied that he was listening to the bird we had studied together in the Alps. That morning we heard a strange variety of imitationsthe Chaffinch, Thrush, Yellow Wagtail, Redstart, Goldfinch, Greenfinch, Partridge, Swallow, Skylark, Whinchat and Blackcap, were all laid under contribution in the course of two or three hours; all of them being birds whose song the artist could study at leisure from the osier-bed. We had also the satisfaction of seeing the bird well-as well as we had seen him in Switzerland; and also of finding a Reed 
Warbler here, so that all three species of Acrocephali were quartered in this space of two acres and a half, -for the Sedge Warbler, I need hardly say, was both abundant and noisy here.

My third witness was my friend Mr. A. Holte Macpherson, whose name is familiar to readers of the Zoologist. He was less lucky than the others, for he ouly saw and heard the bird for a moment. He deserved better of it, for he got up before dawn, and spent the hours from three to eight in a fruitless search for the nest in a smaller osier-bed to which my bird seemed by this time to have moved. We were not to find a nest that year; and it may have been, as Mr. Macpherson conjectured, that, as this was apparently the first visit of the species to our neighbourhood, one or more males had arrived alone, and, failing to find mates in spite of continual singing, had given up the case as hopeless and gone elsewhere. However that might be, we had nothing for it but to hope that next year they would try their luck again, and give us the chance of completing ours.

When the May of the present year (1893) came round with its early foliage and unceasing warmth, I began to listen at the osier-bed; but the withies had been cut in the winter, and the appearance of the place was so much changed that I was inclined to doubt whether the birds would take to it again. 
There was indeed no reason why it should not suit them, for in the Alps the cover which they affected was hardly so high or so dense as this; but arguing from the ways of the Nightingale, which always abandons a wood of which the undergrowth has been cleared in the winter, I felt instinctively that the chance of success would this year be a doubtful one. And so it proved; up to the middle of June I failed to catch even a fragment of the song, and instead of it the osier-bed began to resound with the whirring reel of the Grasshopper Warbler, a bird which I had never before heard so close to the village. I consoled myself as well as I could by watching this little curiosity performing from the top twig of a sapling on many a warm evening after sunset.

On 20th June I was returning from a hot stroll, and languidly leaning over a gate some half mile further up the valley, when my eye chanced to fall on a spot which instantly suggested itself to me as the ideal place for a Marsh Warbler. It was a small bed of osiers, overgrown for the most part, sheltered on one side by a high railway embankment, and on the other by rising cultivated ground; between it and the railway was a deep ditch of running water. It occurred to me as quite possible that my friends of last year might have found a home here; and here in another five minutes I found them. Clearly in these parts an overgrown withy-bed is what they 
love best; and if ornithologists would give closer attention to such places, and boldly plunge into them, regardless of heat, insects, damp, and snakes, they might oftener come across a bird of which so little is still known in England.

That day I did not attempt much, but waited until I could begin a patient watch. I noted that the railway embankment-always a blessing to the naturalist - would answer my purpose admirably. On the 21st I established myself under an umbrella on this flowery bank, and in less than half an hour was able to make a fair guess at the position of the nest. More than once I saw my bird dive into the willows at a point where they were but half-grown, and where search would not be very arduous. Like a Kingfisher swooping from his perch, I descended into the osiers, and there, ten yards from the hedge, I found a nest slung between young saplings as it were by four or five handles; for the twigs were not worked through the whole structure, but only through the rim of it. It was nearly three feet from the ground, and, like all nests of this species that I have seen, conspicuous enough when you have come upon it, though hidden in a mass of stalks. There were no eggs in it, and as I could see daylight through the dry grasses of which it was chiefly composed, I concluded that it was still unfinished.

In a day or two a good deal of moss had been 
added to the outside of the structure- $a$ feature that I have never seen abroad; and a few hairs had been worked into the lining. I began, however, to fear that it might be forsaken, for I thought I saw signs of trespassers in its neighbourhood, and once I was baffled and alarmed to find a ploughboy at work within twenty yards of it. I fancied too that it might turn out to be nothing more than the work of an eccentric Sedge Warbler, for a pair of those excitable birds had once come very close to me while I was looking at it. But I sent for Mr. Macpherson from London to come and share my anxieties: my other two witnesses of last year being, the one in South America-or rather on his way home-and the other deep in mathematical problems in hot examination rooms at Oxford. Macpherson came on the 24th, and I showed him the nest that evening; it was still without eggs, and I was beginning to despair of seeing any, for on the Monday following I must start for my holiday,- - one more brief holiday in the Alps.

Next morning, as I was dressing, my friend broke in on me with the welcome news that an egg had been laid. An unwilling denizen of London, he had again been bathing himself in our country air, though experience had taught him that three o'clock is even too early. We were very soon at the osier-bed, and I at once recognised the egg as that of a Marsh 
Warbler; it was of a greenish white ground-colour, with many dull purplish spots and blotches, especially at the larger end. But our anxieties were even now hardly at an end; for it was Sunday, the day on which the predatory ploughboy roams afield in quest of eggs,-and to him a Marsh Warbler's egg is all the same as a Sparrow's. By this time too there were naturally traces of our doings at the entrance to the osiers, quite obvious enough to attract his attention. It was, in fact, absolutely necessary to set a watch. We divided the day between ourselves and a friendly gardener; the rector of the parish, who was also interested in the discovery, taking a turn as sentinel in the afternoon. The railway afforded us an excellent vantage-ground, and there we marched up and down like sentinels on a rampart, occasionally varying our duty with a search for other nests. At last the evening of that long hot day arrived, and we were able to depart in peace.

Macpherson had to return to London by the early train next morning; but we previously held a council, at which it was decided to take the nest at once, partly because it would be welcome to the Oxford Museum, partly because it would be no longer safe from the village boys, as I was about to go abroad. So in the morning of the 26th a procession started for the osier-bed, consisting of the rector, his family, and myself, fully armed with everything 
necessary to cut away the saplings above and below the nest, and so to preserve it in its original position for exhibition. This was successfully accomplished, and we were delighted to find that a second egg had been laid in the night. In the afternoon I started on my journey to Switzerland, and on the Thursday morning my companion and I (he it was who had been my first witness the year before) found at Stanzstadt another beautiful nest containing five eggs, slung not in saplings or meadowsweet, but in a thick bunch of a nettle-like plant, whose name I do not know. The same day we heard and saw many other Marsh Warblers, and later experience makes me certain that they may be looked for anywhere in Switzerland where there is plenty of mossy or reedy ground, on the margin of lakes or rivers.

I must needs say a word in the last place of the personal appearance of this intimate friend of mine; but this, I must confess, is the most difficult and the least interesting point about him. Of the three species of the genus Acrocephalus which breed every year in these islands, one, the Sedge Warbler ( $A$. phragmitis) is easily distinguishable by the yellowish stripe over each eye, as well as by his habits, eggs, and vociferous outpourings of song. But the other two, the Reed and Marsh Warblers (A. streperus and A. palustris) have grown into distinct species not so much through variations in the colour of their 
plumage as in their habits, song, and the colour of their eggs. It is, in fact, very difficult indeed, even for a practised ornithologist, to distinguish skins of the two species; ${ }^{1}$ and, as will be seen from $\mathrm{Mr}$. Howard Saunders' Manual of British Birds, it is almost hopeless to attempt to figure the two in such a way as to make it clear what the points of difference are. When Professor Newton was editing the first two volumes of Yarrell's well-known work he did not feel justified in treating the Marsh Warbler as a distinct British species; for he had no personal acquaintance with the living bird, and the evidence of such skins as he had seen was to his exact mind inconclusive. The book which I suppose is most popular among amateurs, that of the late Mr. Morris, leaves the Marsh Warbler out altogether, even in the last editiuns. For information about the bird's dress we must go to Mr. Harting's Summer Migrants, or to the account of Professor Fatio of Geneva, as translated in part in Dr. Bree's Birds of Europe, or to Mr. Seebohm's British Birds, or to the colossal work of Mr. Dresser. But I cannot say that these skilled authorities by any means agree among themselves; and I doubt respectfully whether any one of

1 Mr. Saunders tells me, however, that he can distinguish them at a glance by the general coloration : so too Mr. Seebohm. Yet Canon Tristram, with his vast experience of skins, assures me that he cannot easily do so; and I think Professor Newton finds the same difficulty. 
them has examined a really extensive series of the skins of both our species for purposes of comparison.

The fact is that we must take the bird as he has chosen in the course of ages to make himself recognisable-by his song, or, it may be, by his eggs. And we must look out for that song and those eggs not on the reedy banks of streams, where the Reed Warbler is most commonly to be found, but on dry ground not far from water, where there is some kind of low cover such as that which is afforded by osiers, meadowsweet, nettles, and other plants which thrust up stems in crowded bunches. When we have made sure of him in this way we can examine his appearance at leisure, for if the cover be not too dense he will soon be seen perched on some prominent stalk, pouring forth his "chanson matinale," as Fatio aptly calls it. The first time I ever watched him thus delightfully engaged I took a note of his appearance on the spot, and the points I specially noticed were his white throat, which is fluffed out as he sings, his brown head without any visible stripe over the eye -though there seems to be reason to believe that this becomes slightly apparent in mature individuals, - his olive-brown back, and flesh-coloured legs. This description tallies fairly well with those of more learned ornithologists, and I do not think that I could now add anything of importance to it. The Reed Warbler as a living bird differs slightly in having a 
more rufous back and slate-coloured legs; but these differences soon cease to be at all obvious when the birds have been dead some time, and it is this which has caused so much difficulty in identifying the skins of the two species, and in using them for illustration in pictures.

In telling the whole history of my acquaintance with the bird, I have been aiming at giving those who have not yet met with it a better chance of discovering it than they would gain from even the best handbooks. I have told them my own failures and difficulties, in order that they may avoid such experiences themselves, and may not waste time in looking for the bird in places where they are not likely to find him. And I can confidently assure them that a search for a Marsh Warbler in a labyrinthine osierbed may have wonderful charms for an enthusiast, and that flies and gnats, heat and damp, wet ditches and stinging nettles, will lose all their power to annoy when once you have caught the sweet and silvery voice of the bird you have come to make friends with. ${ }^{1}$

1 These last words excited the scorn of a reviewer in the Manchester Guardian, into whose hands this paper fell when issued as a separate pamphlet. But I let them stand; for the birds, by returning to the identical spot this June (1894), have shown that they bore me no permanent ill-will for taking their first nest last year, - the only nest, so far as I can remember, that I have ever taken in my life. I need hardly add that I left them unmolested this time. 


\section{CHAPTER V}

\section{A CHAPTER ON WAGTAILS}

WERE I condemned to live on a desert island, I should wish to have some birds, as well as books, for my companions. Among books I should need some few of those that abound in such choice detail as will easily slip off the mind, and as easily be recalled and enjoyed at the next perusal-a good old word, by the way, which cannot be applied to the reading of every book. Boswell, The Vicar, Jane Austen, Elia, are of this kind; we can peruse them,- the page lies open a while for leisurely enjoyment, and is not feverishly turned. I would have birds too that can be perused; not hasty ones that are up and away the moment they catch sight of you, nor huge ones, such as Mr. Hudson loves, sailing solemnly over your head and vanishing over the hill while you adjust your glass. I would have little ones that come and go regardless of you, dallying about close at hand, pursuing their avocations while you sit and watch them with the same fresh interest that drew you to them twenty years ago. I 
would have Warblers, Redstarts, Flycatchers, or, better still, Wagtails.

It is impossible ever to weary of Wagtails. We are never altogether without them, yet whenever they present themselves to us we are constrained to give them our attention. Some birds you can glance at as you walk and talk, but no sooner does a Wagtail alight on the path in front of you than he compels you to pause and look at him carefully. There are, indeed, scientific reasons why Wagtails should always be noticed; but apart from these there is a neverfailing pleasure in contemplating their symmetry of form, their beauty of colouring, their graceful flight, their unobtrusive confidence, and that constant unresting activity of theirs-an activity which some mysterious grace of mental build never suffers to degenerate into fidgetiness.

There are Wagtails in most parts of the world, and from Britain eastwards to Japan they are abundant, puzzling the ornithologist with their endless varieties of plumage, and utterly declining to be neatly and finally classified. The whole group, it is true, is perfectly well defined, if not by structure, at least by outward appearance, habit, and motion; but the species within the group run into each other in a way which seems to be as baffling as it is instructive. No family of birds has more to tell us of the nature and growth of species; but none needs more careful 
handling, more laborious investigation and travel. Into this labyrinth, however, I am not competent to venture; I may refer once or twice to two species which are, strictly speaking, Continental, but I shall have enough to say, without travelling further, about the three which habitually breed in our island.

These three are-first, the Pied Wagtail, commonly known as the Water Wagtail or Dishwasher, the black and white bird which we all know so well; next, the Yellow Wagtail of the pasture meadows and lazy streams, which comes to us in spring and leaves us in autumn; thirdly, the so-called Gray Wagtail of the mountain brooks and rivers, which can always be distinguished from the others by its very long tail. All these three resemble each other closely in their habits, as well as in their build. They all love the neighbourhood of water; they all have the same peculiar flight-a graceful flight, consisting of successive upward and downward curves, which enables us to detect them even at a long distance. They all have the same quality of voice-a short and shrill musical whistle, which cannot be confused with the note of any other bird, unless it be indeed with that of their nearest relations the Pipits. They all move their tails gently up and down, build their nests on or close to the ground, and lay eggs of which the groundcolour is nearly always a pale bluish white, spotted more or less with brown or gray. They all walk, or 
rather run, instead of hopping, their delicate little legs being often in such swift motion as hardly to be seen as they go; and all feed chiefly on insectslargely, I think, on minute beetles-and love our British streams and meadows for the never-failing abundance of food they find there. And I should add that in all our three birds the two outer tail-feathers are white, and become conspicuous the moment their owner flies or moves his tail in the familiar way: a characteristic of which I may have something to say later on.

These are the generic peculiarities of the group, and, as far as I know, they are common to all true Wagtails. But our three British species, though they are alike in so many ways, and are without doubt all descended from a single ancestral type, have developed features which mark them off very clearly from each other. The colouring, for example, is so distinct in the plumage of the adult male birds in breeding dress, as to be recognised at once even by the inexperienced ; and it is interesting to find that they then represent three several types of the world's Wagtails. One is black and white, with a jet-black gorget; one is yellow and olive-brown, with no black at all; and the third, which stands between the two, though I take him last in this chapter, is gray above, bright yellow beneath, and has the same black throat ornament as his Pied cousin. Or to put it shortly, 
one is typical of a black series, another of a yellow series; while the third has something to show us both of black and yellow. Our British Wagtails, then, are well worth careful study; for, however far an inquirer may travel in quest of Wagtails, he is not likely to find any, either in museums or in nature, which do not come near to one of these three types.

Let us begin with the black and white bird ; him at least we can hardly fail to find at any time of the year. But where shall we look for him? Not necessarily by the brook-side; but if a farmyard pond is at hand, or a bit of shallow in the stream-a miniature ford, perhaps, with stepping-stones-you may do well to give a glance there. In spring or autumn try a field which is being ploughed; the first field the farmer turns is sure to have its Pied Wagtails. If they chance to be on migration they will collect there to enjoy the minute creatures which the plough exposes, and you may see scores and even hundreds of them hard at work together. The chance will be a good one, if it be autumn, for noting the variety of plumage in both old and young, and for making so sure of this bird that you can never mistake him for his whiter cousin of the Continent. In the breeding season a freshly-mown lawn has a great attraction for him; the meadow grass is then either growing to hay or getting so thick and coarse that it is not easy to find the insects in it. I fancy too that all Wagtails 
like to use their little legs freely, unhampered by thick stalks of crowded herbage; on a lawn they can see insects at a distance, and run with sudden spurts, half flying too sometimes, to seize them. While eating and while running the tail is mostly still; but no sooner is the run over and a fresh morsel pounced on, than it is moved up and down rapidly, showing plainly the two outer white feathers.

But his nest may be some distance away from the lawn he patronises, and we are not likely to find it unless we have ample time to watch. This bird is very apt to choose odd places, and many stories have been told of his caprice in this way. Caprice it may indeed seem to us, but I cannot but think it has an object-to escape the constant persecution of the Cuckoo. It was for this reason, I am sure, that a pair in the garden of a friend of mine built a nest in the far recesses of a greenhouse, among the flowerpots. This nest was a singular one, and must have cost the birds infinitely more labour than usual ; for as it was not fitted into any hole, or supported by anything but the shelf on which it stood, a strong substructure had to be built first, on which it could securely rest. The mass of dry grass and moss was quite wonderful, and all the more pity that it should have been collected in vain. The pair escaped from one enemy only to fall victims to another. The Cuckoo found them out, but was herself found out 
by the gardener before she had actually deposited her egg; and all might have gone well if a cat had not strayed that way. That the Cuckoo should have followed the birds into the greenhouse just at the time when all was ripe for its mischief-for there were then four eggs in the nest-seems to me to show that it had been watching this pair of birds for some time; this the Wagtails well knew, and, abandoning perhaps their original intention, chose this unlikely place.

I think this must also be the explanation of that curious fondness of this bird for railway stations, which I have noticed not only in my own parish but in all parts of the kingdom. When I say that almost every country station has its pair, I am not going very much beyond the facts. Here at Kingham it has been so ever since I began to notice birds; the familiar little double note from the station roof is so well known to me that I now barely stop to notice it. At one time they used to build in the crevices of the stacks of coal; this year there was a nest almost under the signal-box, and just beneath the massive wooden posts fixed at the end of a siding to resist the force of shunted trucks. They are conspicuous birds, and the Cuckoo would soon find them out if they gave him a fair chance; but the bustle of men and trains perhaps deters the malignant enemy. ${ }^{1}$

1 I have somewhere read of a pair that built on the axle of a shunted railway carriage on a branch line; when the carriage was 
When the nesting time is over, the parents and their young broods, after spending the day on lawn or meadow, will associate in roosting in some convenient cover. Early in July I have found them in numbers in a small osier-bed, while looking for the Marsh Warbler towards sunset. But the autumn is the time to look out for their great gatherings. Then they travel in multitudes, hardly observable by day, when they are often on the newly-ploughed fields, but if you should happen to come upon them at nightfall, fairly astonishing you with their numbers. On the 9 th of last October, the last day of my long vacation, I strolled at sunset down to the meadow of which part is occupied by the osier-bed that first attracted the Marsh Warbler; it was fast getting dark, but I at once heard the shrill double notes all round me. All along the stream I put Pied Wagtails up at every step; then turning up to the railway which runs above the field, I saw the telegraph wires covered with them. With the help of the glass I counted forty-five on the wires and another forty on the grass just below them; then I went to the osier-bed and threw a stone into it, which brought out a cloud of wagtails, disturbed from their first sleep.

The next time I was able to pay this wonderful brought into use again the hen bird continued to sit on her eggs during successive journeys, and finally reared her young. 
field a visit there was only a pair or two to be seen, and I have no doubt that this great gathering meant migration. We have abundant evidence that the Pied Wagtail passes over to the Continent in great numbers in the autumn, though there are always enough left behind to let us feel that they are still with us. Some years ago an old friend of mine, a master at Westward Ho College in North Devon, wrote to me just at the end of September describing a strange immigration of Pied Wagtails which had occurred there a day or two before. It was a warm evening, and the windows of the large school building, which fronts the sea, were open, and the lights within were of course visible out at sea. Suddenly the rooms were invaded by a host of Pied Wagtails, which swarmed in, circling round and round the ceiling like bats, and so distracted that they could be caught with butterfly nets. These were probably the Welsh Wagtails, making their autumnal journey to the south coast of England on their way to the Continent; and on this same coast of North Devon parties may be seen in the autumn making progress towards the west, to cross the county to the southern coast, where they seem to congregate for further travel.

We can trace this travel, and find that it is now directed towards the east. On the coast of Dorset I have seen them gathered in vast numbers in late 
September; and I need only refer to Mr. Knox's Ornithological Rambles in Sussex for a well-known and admirable account of their journeying in that district. Somewhat further eastward they cross the Channel, and some at least then go southward along the French coast, for we catch a glimpse of them again in Portugal. Mr. W. C. Tait in the Ibis for 1887 tells us that this species "arrives in the neighbourhood of Oporto about the 20th of October, winters here, moults to summer plumage in March, and departs." 1

Once arrived on the Continent, they must find themselves comparative strangers : for though they are among their own kin, the White Wagtails, they do not seem to be always received with the hospitality due to near relations. Mr. Tait goes on to tell us that he has seen Pied Wagtails attacked on their arrival by the resident White Wagtails, who looked on them as intruders. Yet these two species -incomplete they may be as species, yet something more than mere races or varying forms-will sometimes associate, and even mate, together. The White Wagtail, which is a pretty constant visitor to this country in spring, may sometimes find himself (or herself) without a mate, and take up with a Pied Wagtail in default of his own kind. Such a pair were found in Norfolk by Lord Walsingham, and

1 Vol. v. No. 18, p. 186. 
presented to the British Museum with their nest and young. On 25th June 1890 I was walking with Mr. O. V. Aplin near Banbury, when by a large mill-pond we found a pair of Wagtails, of which the male was undoubtedly a Pied Wagtail, while the female was gray all over, including the head. That this female was a White Wagtail was Mr. Aplin's conclusion on the spot, and I believe that he still thinks so. The female White Wagtail, he told me, occasionally has a gray head, instead of the neat black cap that contrasts so strikingly with the pearl-gray of the back in this species; and, if I recollect right, we were able to confirm this statement during a visit to the Continent the next year. But the endless varieties of Wagtail plumage, in old and young, and male and female, at different times of the year, must be left to those who have time and materials for a close and accurate study.

When the Pied Wagtail was first distinguished by naturalists from its Continental cousins, it received the unfortunate name of Motacilla lugubris, or the Wagtail in mourning, in allusion to its black and white dress. ${ }^{1}$ To give such a name to such a bird is to forget that he is something more than an

1 It is now generally known as M. Yarrellii, a name given it by Gould in honour of his friend Yarrell. Thus both those forms of Wagtail which are specially associated with this country bear very appropriately the names of English naturalists. The Continental forms are $M$. alba and $M$. flava. 
"arrangement" in feathers; I do not think that a Wagtail could look mournful even under the most painful circumstances. No such misfortune, I am glad to say, has happened to the Yellow Wagtail, the sprightliest, boldest, and perhaps the happiest, of its kind. It has often been called, in Latin as well as English, simply the Yellow Wagtail; but the greater number of authors have given it, in a Latin form, the name of the great English naturalist John Ray, and even in common speech we often speak of it as Ray's Wagtail.

It received this honourable name some half a century ago, because it was then first discovered that, like the Pied Wagtail, it is almost peculiar to Britain, and is quite distinct from the common Yellow Wagtail of the Continent. I have never myself seen it abroad, and it is certainly a rare straggler at any distance from the shores that lie opposite our island. Strange to say, it is found in Central Asia in summer; and, as it is known to winter in Africa, even as far south as the Transvaal, it may be that two currents of Yellow Wagtails leave Africa in the spring, the one going north-east to Asia, and the other north-west to Great Britain. Here at least is one of those curious involved bird-mysteries which make the science of ornithology more fascinating the more our knowledge of it advances. And, to add to our perplexity, we have also to face the fact that the 
I08 Summer Studies of Birds and Books chap.

space between these two currents is occupied by several other kinds of Yellow Wagtails, all much alike in shape and habits, and for the most part in hue, but differing just in some one point of plumage, and mixing themselves up together in the most delightful confusion, as if to make the men of science pay for classifying them. ${ }^{1}$

The only one of these I shall mention here is the Blue-headed Wagtail of the Continent, the type of its class. A few of these seem to come to us every year; and just as it is worth while always to look at Pied Wagtails to make sure that they are not White Wagtails, so it is as well to glance at all yellow birds we see, in case we should some day meet with one that has a distinctly bluish head, and a white stripe over the eye instead of a yellow one. A beginner, indeed, may easily confuse the female of the common species for the rarity he is looking out for; and he should never be satisfied until he has watched his bird at a very short distance, and if possible with a good field-glass. Though Oxford is a favourite haunt of Yellow Wagtails, I have in the course of many years detected but two or three of the rarer species.

1 See Seebohm's British Birds, vol. ii. p. 212 ; Giglioli's Avifauna Italica, p. 81. In the Zoologist for November 1892 is an interesting note by Mr. John Cordeaux on the peculiar migration of this bird. 
These most charming birds come to Oxford about the middle of April. ${ }^{1}$ They come up the river, and gather in great numbers on that vast meadow above the city known as Port Meadow; which almost deserves a chapter to itself, so interesting is its history, so rich its treasures of birds and plants, and so various its aspect in flood and frost, under sunshine and shower. Here, on the 26th of April 1887, I saw a more wonderful gathering of Yellow Wagtails than I have ever seen since, or am likely ever to see again. Mr. Arthur Macpherson had come into my rooms the evening before, to tell me that he had seen some Dunlins on the bank of the Isis, where it bounds this great meadow to the west. As these birds of the sea-shore had never before been reported to me, I started the next afternoon, hindered and baffled by a strong and bitter wind which soon turned to pelting rain, and by a toothache which raged in sympathy with the elements; but I was rewarded for my pains. I found the Dunlins; but I found also what was far more wonderful and beautiful-the whole length of the river's bank, on the meadow side of it, occupied by countless Yellow Wagtails. As I walked along they got up literally

1 They are apt, like some other migrants, to appear earlier in the west country: I have seen one at Westward Ho on 4th April, in company with newly-arrived Pied Wagtails in brilliant plumage. The latest date in the autumn $I$ have a record of is 10 th October. 
I I Summer Studies of Birds and Books chap.

from under my feet; for they were sheltering just beneath the meadow's lip, and I came upon them quite unawares. When a turn in the bank gave me a view ahead, I could see the turf spotted all over with the brilliant yellow of their breasts; for I was walking with the wind, and they, of course, were facing it, to avoid having their plumage uncomfortably handled by the gusts.

They were not afraid of me, and settled down again directly I had passed on, so that my progress was like that of a haymaking machine, which just lifts the hay as it passes, and then lets it settle down again after dallying a moment with the breeze. These birds had clearly only just arrived after their long journey from Africa, and I think they must have come together and unpaired; the greater number of them were males. ${ }^{1}$ Their numbers diminished regularly day by day, and at the same time I began to see pairs in their usual places in the neighbourhood evidently preparing to nest. In a few days they were nearly all distributed over the country-side.

Since then I have looked out for them every year, and have always seen plenty in mid-April on this same meadow, but never again such a wonderful assemblage. The nearest approach to it was on 22nd April of this present year, 1894. I had walked

1 I never, however, remember to have seen a newly-arrived flock of this species without at least two or three females in it. 
some miles up the river without seeing a single Wagtail, and had made up my mind that they had not yet corne, when, as I was returning home across the Port Meadow, my dog ran into a bevy of them, and sent them dancing into the air, uttering their bright shrill whistle. As before, they soon settled down again; and now I noticed how hard it was to see them on the ground. Their greenish-brown backs assimilated admirably with the freshly-grown grass, and their breasts were hardly to be distinguished from the marigolds among which they had settled. They were not in such numbers as in 1887, and indeed they are less numerous all round us this year than usual-a diminution which is by no means to be attributed to the depredations of mankind, as some unthinking persons would have us believe in the case of this and other interesting species. Few birds are so little molested as the Yellow Wagtail, for their nests are very hard to find, and rarely or never discovered by the ploughboy; and we must be content to confess our ignorance of the causes which increase or diminish their numbers. ${ }^{1}$

Of the nesting of the Yellow Wagtail among these marigolds and buttercups I can say nothing from

1 So too with the Gray Wagtail, which during the last year has (in my experience) been far less common than it was a few years ago. But this present autumn (1894) it has reappeared in its accustomed winter haunts. 
personal experience. I have never found the nest, and it is so well concealed as to have baffled the most indefatigable nest-finder I know. The birds are so restless, and so happily artful in misleading you, that even if you know within twenty yards or so where the nest must be, the task of finding it needs more time and patience than most of us have to spare. To judge by the beautiful specimen in Lord Walsingham's collection at South Kensington, the nest itself is so well concealed as to escape your notice even if you are almost treading on it; and the eggs are spotted all over with a soft yellowish brown, which helps to hide them among the yellow-green stalks of the grass and the darker shadows cast by taller plants. ${ }^{1}$

But though it thus hides its nest and eggs with infinite care, it is astonishing how bold this little bird will be in the breeding time; more than once it has let me approach it within a yard or two as it runs delicately through the grass, picking off invisible insects from the fresh shoots; and several times I have known it decoy both me and my dog away from the nest, by letting us come very close, and then running or half flying a little way on in front. It knows very well that a dog is dangerous; and I once

1 They do not invariably nest among the flowers and herbage; a nest was found this spring on a dunghill near my village. As the manure was needed on the farm, it was taken, eggs and all. 
saw both cock and hen stand up to Billy in such a ludicrously determined way, - the cock in front as if to protect his wife,- - that I stopped the dog with a sign, and the big and little animals continued to regard each other on equal terms, until my irrepressible laughter sent the Wagtails off.

When the young are able to fly, I know no more beautiful sight than to watch them playing in a hayfield. True, they are not of the bright yellow their parents wear,- - they are often almost wholly brown, though they differ considerably from each other; but their movements in the air it is a constant pleasure to watch. They dance and spring and twist and turn,-now they are on the ground, now high in air, now at the other end of the field, and now as suddenly back again. Nor do they limit themselves to the hay-fields, or to the pastures where they run about among the legs of the grazing cattle. I have repeatedly seen them in osier-beds, on telegraph wires, on the top branches of high trees, and in cornfields, perching on the ears of wheat. So light and sylph-like are they that the stalks were hardly bent beneath their weight; and I could not help singling out one of these on which a bird had been resting, and trying to measure with the touch of my finger the weight of that fairy figure. Another day I watched a family perched upon the telegraph wires; they let me come close underneath them, and 


\section{4 Summer Studies of Birds and Books chap.}

now and then performed the feat of running sideways along the wires, holding on chiefly by means of the hind claw, which is very long. This claw was brought round below the wire to join the others, and thus around each wire a complete little ring was formed, which seemed to slide along it when the birds moved.

The tail of this bird is not so long in proportion as in the two other Wagtails, nor is it moved so frequently or regularly. As he runs about among the cows you will see very little "wagging" going on -hardly more than in the common Meadow-pipit. But no sooner does he take to flight than his tail becomes the most conspicuous part of him; it seems to twist and open, showing clearly the pure white outer feathers, and when he once more alights, it will be vibrated two or three times. Then the movement ceases, and the white is hardly to be seen.

The mention of tails brings me naturally to the last and the most beautiful of our three species, the so-called Gray Wagtail of the running streams; for in his case the tail is not only the most prominent feature, as it is in all Wagtails, but is longer than in the rest, and in much more constant motion. Here there are no ornithological puzzles to detain us. It seems that you may roam over the whole continents of Europe and Asia, and see the same bird that 
haunts our own mountain streams. They say, indeed, that in the East his tail is a trifle shorter; and I have a note, written before I knew this, that in the Alps the tails struck me as being hardly so long as they are with us; but they are quite long enough to mark the bird, and they are everywhere moved up and down with that grave and regular persistence which belongs to no other Wagtail.

Every fisherman knows the Gray Wagtail, and will bear me out when I say once more that gray is not quite the word for him. If he stands facing you as you fish up-stream, he will show you his black gorget of the breeding season, and the beautiful yellow of his under parts, which has given him the scientific name of sulphurea; or if you chance to see him from behind, though his head and back will show slate-gray, yet this as it nears the tail becomes greenish-yellow, and the tail itself is not gray, but nearly black in colour, with the two outer feathers bright white. The bird is in fact at a first glance not unlike the Yellow Wagtail, with which it has often been confused; but the black gorget brings it rather into relation with the Pied Wagtail, which has the same conspicuous addition to its dress in spring. Yet from both birds it is quite distinct, in habits as well as appearance, and seems to stand entirely by itself in the little world of Wagtails. 


\section{6 Summer Studies of Birds and Books chap.}

In this island it is always resident $;^{1}$ but here, and apparently in all countries where it dwells, it desires a change of scene, and perhaps of food, in autumn. In the lower and flatter lands it is rarely seen in spring and summer; in Oxfordshire it seldom fails to appear in September or even earlier, and as regularly leaves us in January or February. ${ }^{2}$ Now and again a pair will stay to breed by some lock or mill-dam, where they find the constant rush of water which they so dearly love; but only once, so far as I know, has the nest been actually found in our county. In June 1890, during the same walk which showed us the Pied and White Wagtails interbreeding, Mr. Aplin and I were passing another mill, when I caught sight of a long tail moving up and down by the water-side under the long herbage. A Gray Wagtail in June meant a nest for certain, and we found it almost at once in the wall of the mill-rush; two eggs had been hatched, and the nestlings were ash-gray above, and distinctly yellow beneath. While we were looking at them the parents continued to dance in the air

1 I have little doubt, however, that some cross to the Continent every autumn. They appear regularly in September on the coast of Dorset, in a dry chalky country which they would never patronise but on a journey.

2 It is a melancholy fact that we have seen less of them the last year or two; last winter (1893-4) I hardly saw one. I am quite unable to account for this; certainly it is not due to persecution. 
about us, uttering a peculiar note of alarm; their brilliant colours and exquisitely elegant movements kept us watching them much longer than they themselves could have wished.

I have once known this bird build at some little distance from tumbling water, and in a position where I should never have thought of looking for the nest. I was strolling before breakfast in the garden of the Hotel Titlis at Engelberg, in which there is a small ornamental water, with a boat and boathouse. Standing on a bridge which crossed this water, I watched a Gray Wagtail with food in its bill which was hovering about the entrance of this boathouse. At last it went in, and, following it, I found the nest on the timber shelf from which the roof sprang. Later on, with the help of Mr. Playne's lusty shoulders, I managed to get a look into it; it was large and untidy, like the Pied Wagtail's nest in the greenhouse, or like those of the Spotted Flycatcher which, until certain "improvements" took place, used every year to be built in a similar position in the garden of the excellent Hotel Bellevue at Bern.

So long as the young broods are unable wholly to shift for themselves, they seem to keep together under the eye of the parents, and will play together like Wagtails of other kinds. On 26th June 1887 I was strolling on a mountain path in the Bernese 
Oberland, and carne suddenly into a little glen, down which a stream rushed babbling, at the foot of a wall of rock some fifty feet high. Dancing about stream and rock, like black and yellow fairies, and occasionally resting on the rock's face, or on the young pines which grew about it, was a family, or perhaps two families, of these most graceful birds. So restless were they, so quick and nimble, that the eye could hardly follow them, and it was with the greatest difficulty that I got my glass fixed on one of them. The same agility is shown when they come down in September from the mountains, which are then getting too cool for them, and congregate by the banks of some large river in a valley. I have seen them in great numbers just after their arrival, very busy in catching flies over the water of a rushing glacier-stream, and mixing with their cousins the White Wagtails; the air was full of dancing birds, and the banks alive with gentlymoving tails. As they hung in air over the stream, the tail was often spread out wide, like that of a hovering Kestrel, while the rapidly-moving wings danced them up and down.

But as a rule, when grown older, the Gray Wagtails are somewhat quiet and deliberate in their ways, though always full of grace; they are, if I may use the word of both sexes, extremely ladylike birds. And there is a look in them of great content, 
and even of self-satisfaction, as they trip along, unaware that they are observed, by the water's edge ; with no lack of food, with the pleasant noise of the water ever in their ears, and with those long tails of theirs perpetually moving up and down, as if in rhythm with the water. It is worth noting that the motion of these tails is not exactly that which we have observed in the other two species; it is not so purely a tail-motion, and it is less rapid and more regular. It is a motion of the whole body from the breast tailwards; it is only the great length of the feathers that gives it the appearance of belonging to the tail only. The verb to wag is utterly inapplicable to it, nor can I think of any word which will exactly express it. One other bird that haunts our British streams has the very same movement of the whole body, and this is one which has but little tail - the Common Sandpiper.

Before I leave these tails I have yet a few words to say about them. In this scientific age, when questions beginning with why are always being asked, if seldom finally answered, I might feel it a duty to the Wagtails to ask the reason of their tailmotions. I do not indeed promise to explain them, -not at least with the easy conviction of a certain popular writer, who (though it is but lately that he learnt the difference between the Gray and the Yellow Wagtails) assures us boldly that the object 
of the motion is to aid the bird in balancing itself. It is true enough, no doubt, that the tail of every bird is of use to it in this way, especially in the air; but the peculiar motion of the tails I am writing of cannot possibly be needed for this purpose. If the bird were likely to topple over into the water while sitting on the edge of a stone,-a supposition in itself absurd,--I imagine that it would most naturally keep its tail well down, rather than wave it up and down rapidly. But surely no bird needs any peculiar action to enable it to keep its equipoise; even a sparrow without a tail can do this perfectly well. Again, if the Wagtails need long tails and a peculiar motion to keep them steady, how does the Dipper manage-a bird that needs balancing on slippery stones as much at least as they? His tail is short, his form less shapely than that of a Wagtail, and as he sits on the edge of a stone making bows at you, he takes no such precautions to save himself from a tumble as in his ignorance of a bird's make and habits this writer attributes to the Wagtails.

For several years I have closely observed the tail-motions, not only of Wagtails, but of a great variety of birds, and I may fairly venture to express an opinion about them. It is a familiar fact that many animals use their tails to express certain emotions; for the tail is directly connected with the 
spinal cord and the brain, and may become an index or reflector of what is going on within that brain. Tails may of course be used in different ways; the cat waves its tail when it is angry, the dog when it is pleased. That is merely matter of habit; but in each case the motion is the result of some affection of the nervous system. Now the nervous system of birds is very sensitive, if we may judge by their restlessness, and by the extreme vigilance and rapidity of their sight and all their motions. And this in many birds, and especially in small ones, is apt to show itself in the tail, which is flickered horizontally, as in the Redstart, or jerked upwards, as in the Wren and Moorhen, or twitched several times in a minute, as in the Yellowhammer and Reed Bunting, the Wheatear and Whinchat, and others. ${ }^{1} \quad$ The motion may mean either simple satisfaction, or sometimes distress and alarm. With most of the birds I have mentioned the former is the cause, though not, I think, invariably; but watch a Red-backed Shrike as you approach his nest or young, and you will see a good example of the effect of anger on a tail. He sits on the top of the hedge, swinging his tail from side to side, as well as up and down, with a motion quite peculiar to

1 A motion of the wings often accompanies that of the tail; and in some birds, as the Chats and most Buntings, a note of some kind is uttered at the same time. 
himself, and uttering cries that make the meaning of the motion unmistakable.

The tail-motion of the Wagtails, if I am not mistaken, is no great mystery; it is no more than a nervous trick, which in their case, as in that of so many others, expresses happiness and satisfaction. The Pied Wagtail which I watched on the lawn half an hour ago showed me this as plainly as possible. When he first alighted on the lawn he "wagged" his tail, and every time he caught an insect he did so. The Gray Wagtail, a quieter bird, as we have seen, has developed a habit of constant motion which is, indeed, second nature with him, and as plainly speaks his content with his surroundings as does the flicker of the Redstart in the orchard.

But we are not yet quite at the end of the matter. Every one who has noticed these tail-motions at all must have been struck by their constant correlation with those white feathers which are so conspicuous in the Wagtails. And the Wagtails are by no means alone in this peculiarity; for it is astonishing how many European birds show white either in their tails or tail-coverts, and how large a number of these have some nervous trick which makes this white conspicuous. ${ }^{1}$ The Moorhen is a good example. I have seen

1 When the tails are not made conspicuous by white (or in a few cases red) feathers, there is as a rule no special tail-motion. Skulking birds, like many of the Warblers, have neither motion nor 
her leading her young brood across the water, jerking her tail so that its white is constantly visible to them, and at the same time calling them to follow the standard they see thus held out for them. I have seen an old Reed Bunting sitting on a rail and calling his young about him, while at every twitch of his tail it was just so much expanded as to show the white, and with the white his position. I believe, then, that in these and some other instances the nervous trick has a secondary use; it is not only a sign of satisfaction, but also a signal, and the white is a recognition mark, as Mr. Wallace has called it.

If I were to go into the whole question of recognition marks in birds, I should be wandering beyond the limits of this chapter. Let me finish it, before I am tempted to stray further, by asking those who find a pleasure in Wagtails to observe their tails at leisure, and to let me know if they find reason to doubt that their motion is a nervous habit, arising in the first instance from mental satisfaction, but capable of being turned to good account as signals to their families and friends.

white. And it is worth noting that birds which have both are apt to choose conspicuous places for perching, as the Wheatear, Stonechat, Whinchat, Bullfinch, the Shrikes, and the Buntings. 


\section{CHAPTER VI}

ON THE SONGS OF BIRDS

IN this chapter I shall be on ground that is in one sense familiar to every one. Even those who can barely distinguish the song of a Blackbird from that of a Wren have at least some idea of what a bird's voice sounds like. To almost all of us the songs of birds are as welcome in spring as the wild roses are in June or the fireside at Christmas. And may we not add that, just as birds are of all animals the most beautiful and fascinating in their movements and habits, so of all the sounds which wild nature brings to the human ear their songs are the most powerful in their contribution to our happiness? Men high and low, rich and poor, have always felt this, and always will feel it; admitting, half unconsciously perhaps, the spell of the music in spring, and missing it in winter from the leafless trees-those "bare ruined choirs where late the sweet birds sang."

I have called these utterances music, and the exquisite line I have just quoted from Shakespeare 
shows that he, like all true poets ancient and modern, thought of them as music and song in something more than metaphor. But as one whose enjoyment and knowledge of music is much older even than his study of ornithology, I will venture to raise a question about their musical quality which I have never seen quite adequately discussed. In what sense can we traly call them music? What is their relation to our modern musical art?

Without doubt the best of them consist chiefly of musical sounds, and are not merely noises, for they are produced by an instrument the same in kind, though not the same in the detail of its mechanism, as the human voice and some of our musical instruments. I say the best of them; for we must not forget that the birds which have learnt to play upon their instrument with a really pleasing result are very few indeed, and that some have that instrument incomplete, while a few do not possess it at all. But where it is perfect the singing apparatus of a bird is a legitimate musical instrument, consisting of a long tube and a tiny membrane which vibrates under the transmission of air from the lungs, and it is played upon, or modulated, by muscles which tighten and relax like the lips of a performer on a reed instrument. The method of producing the sound is in fact very much the same in the bird and in a reed instrument; and this may account for what I may call the 


\section{26 Summer Studies of Birds and Books chap.}

reedy quality of the voices of most birds, for even those of Blackbird and Blackcap, mellow as they seem, will be found to have something of this quality if we approach the birds quite closely.

To make this point a little clearer I place side by side a cut of the simplest form of oboe, and one of the normal type of vocal instrument in a bird.

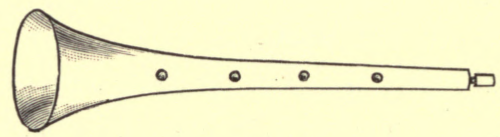

Fig. A.

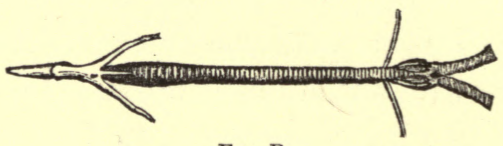

Fig. B.

In $\mathrm{A}$ the sound is produced by the reed affixed to the small end of the instrument, which vibrates between the lips of the player as he breathes air into it from his lungs. The reed, I should say, is made of two bits of very flexible wood fixed one on the other so as to fit exactly; these vibrate as the air from the lungs passes through them, and this vibration is communicated to the column of air in the pipe of the oboe. The result, if the instrument be constructed in accordance with the principles of acoustics, is a true musical sound. 
The figure $\mathrm{B}$ represents the musical instrument of a bird. It may be a Rook's, or it may be a Nightingale's; there is no difference in the make of the instrument, and the difference in the voice depends simply on the size of the instrument and the skill of the performer. The sound is produced in the same way by all our songsters, and on the same principle as in the oboe. The bird breathes from its lungs into two bronchial tubes; at the point where these two tubes combine into one there is fixed a tiny elastic membrane, ${ }^{1}$ which serves the same purpose as a reed, and sets the air vibrating in the pipe which corresponds to the pipe in the oboe, i.e. the bird's windpipe. We are apt to fancy that the bird sings with his bill or his tongue, but this is altogether a mistake. It is possible that these may have some kind of influence upon the sound, but that sound is produced far down in the bird's throat, at the thin end of the tube, just as it is in the oboe.

The two instruments are thus really alike; yet there is a difference, not only in the material of which they are made, but in the way in which they are used. Or, to put it another way, the difference of material makes it inevitable that the methods of playing upon them should also be different. In the oboe the tube is of wood, and therefore hard and inelastic; of itself it cannot alter the pitch of the

1 See Appendix and plate at end of volume. 
sound produced by it. But in order to alter the pitch, holes have been punched in the tube, by stopping which with the fingers you can make the vibrating column of air in the tube longer or shorter at will, and thereby alter the pitch of the sound; just as in the trombone the same thing is effected by moving one tube up and down within the other.

But in B, the bird's instrument, the tube is not hard or stiff; it is as elastic as the body of a worm, and is indeed not unlike that curious compound of rings. It can be lengthened and shortened, squeezed and relaxed, by the many strong muscles which are attached to it; and these give the bird a capacity, whether or no he choose to take advantage of it, of producing an almost endless variety of pitch. Some birds when in full song, the Nightingale for example, will draw their throats in and out, while at the same time the feathers are set quivering with the vibration going on within. These motions are caused by the lengthening and shortening of the tube, while at the same time the whole instrument is in strong vibration. No wonder then that the sounds produced by such an instrument are, or can be, endless in variety, and often beautiful in tone.

But this instrument is a natural and wild one, untempered and unfettered by human science or art; and the sounds it produces are not all of them musical sounds in the true sense, even in the very best bird- 
songs. There is hardly a bird so completely master of its instrument as never to lapse into sounds that are rather noise than music,-or, in technical language, sounds caused by vibrations that are not repeated at exactly equal and very small intervals. And in some very curious "songs," such as those of the Grasshopper Warbler and Wood-wren, which are like the winding of a watch or a fishing-reel, there is really no musical sound at all. Songs we call them, for they are pleasant to the ear, and fully answer the purpose of a song; but they are not sounds which can properly be called musical.

But the voices of our best singers, Nightingale, Song-thrush, Blackcap, Blackbird, Robin, Skylark, and others, are for the most part really musical; these play upon instruments which constant use and natural selection has rendered wonderfully pleasing in tone, and the fact that they perform (unlike the boisterous Canary) out of doors, and among many other sounds, prevents the sensitive ear from feeling their wildness too painfully. But in what sense are they music? We may fairly enough call them musical, but how nearly do they approach to the nature of our highly-developed art?

The question can be answered without much difficulty by any one who has a sufficiently trained ear, and will take the trouble to try and write down in musical notation some of the songs he hears. His 
first task will be to fix, by means of a delicate pitchpipe, the note on which the bird starts his song, and so, as far as may be possible, to fix the key or tonality of it. But this, though only the initial step, is often extremely difficult to accomplish; and you can by no means always be sure that, even if there be a real tonality in the strain, it can be determined by making sure of the first note. And when you go further and try to photograph on paper the whole strain or even a part of it, you are confronted with such difficulties as can be overcome by nothing less powerful than a lively imagination. My own attempts of this kind have been signal failures; but I should not be justified on that account in thinking the task a hopeless one, if I were not wholly unable to appreciate the attempts which others have thought to be successful. To take an example: I have seen the song of the Willow-wren represented by a descending scale of notes from $\mathrm{E}$ in the treble to $\mathrm{C}$ ten notes below, and I quite understand why this succession of notes is selected. But I wholly deny that the Willow-wren prefers to sing in $\mathrm{C}$ major, and I much doubt whether there be in his song-one to which I must have listened many thousands of times-more than one full tone of our musical scale. ${ }^{1}$ This is one of those songs which

1 The notation of this song will be found in Mr. Harting's Birds of Middlesex, p. 58. In the same book is an attempt to reproduce 
might seem at first hearing to lend themselves fairly well to notation ; but of others, such as the Nightingale's or the Robin's, I would say without hesitation that any attempt so to represent them would be pure waste of time. A poet can be translated from his own language into another with some show of success; but to write the song of the Robin on a musical stave is in my opinion not only to translate him but to traduce him. You may imitate a bird's song, it is true, on some instrument made especially for the purpose; but that is a very different thing from writing down on music-paper either the song itself or the imitation of it.

There is a very plain reason why all such attempts should be futile. The birds use no fixed intervals such as those in our artificial scale; their voices are wholly free and unfettered by convention, and they can make free use of any of the infinite number of intervals which in reality exist between one of our tones and another. This is simply the result of the nature of the bird's vocal apparatus,-of the combination of syrinx, windpipe, and muscular system; the windpipe being so elastic, as I have already the Blackcap's warble, in which I am unable to trace any resemblance to the song as I know it. Many other curious examples are given in an interesting book called Woodnotes Wild, by S. P. Chancy (Boston, U.S., 1892), together with a useful bibliography of the subject. Mr. Chancy was an ardent lover of birds, and a musician as well ; and I sincerely regret that I am unable to judge of his success in dealing with the songs of American birds. 


\section{32 Summer Studies of Birds and Books cHap.}

explained, as to be capable of producing, under the action of the muscles, an infinite number of musical intervals when the column of air in it is set vibrating by the vibrations of the syrinx. It is not often that birds hit upon a succession of even two or three notes which closely correspond to intervals in our scale. The Cuckoo does so, though not often very exactly, and so too does the Song-thrush; and very careful training may bring some birds to whistle a human tune, - at best a melancholy travesty, unworthy alike of man and bird. Once, indeed, I heard a caged Blackbird sing, as I fancied, a beautiful phrase which occurs in the first allegro of Beethoven's Sonata for piano and violin in $\mathrm{G}$ major, No. $10 ;^{1}$ and I made inquiry, without result, whether the bird had ever had a chance of hearing that beautiful movement. Again, in the music of the older masters, who wrote when music was fresh and young, I seem often to hear the songs of birds. There is a quartet of Mozart's for strings (No. 4 in B flat) which is full of

1 The phrase is

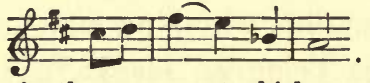

And this is not the only phrase in the movement which reminds me of the Blackbird. The song of the Yellowhammer, which is said to have suggested the famous opening notes of the Symphony in C minor, is also to be caught here and there in the allegretto of the string quartet in F major, Op. 59, No. 1. No one acquainted with the great composer's method and power of developing his themes from trifling origins by constant meditation will be astonished at these apparent coincidences. 
such short, sweet phrases as the best bird-singers delight in; yet I am disposed to think that the impression thus made on me is one of fancy and association rather than of reality. When, as in the andante of Beethoven's Pastoral Symphony, the voices of birds are consciously imitated, the effect, though not unpleasing, is not truly artistic; and we are reconciled to it only because it is immediately followed by a really beautiful phrase, which brings us back at once into the region of true music.

I maintain, then, that the songs of birds have no true relation to our music, which is a highly-developed product of science and art combined; that you cannot write them down on our musical scale without depriving them of all that freedom and wildness in which their very life and beauty consist; and that they cannot be played upon a highly artistic instrument of man's making, though they can be rudely imitated on a rude one. If they are to be compared with anything human, it should rather be with that rude music of primitive man out of which our own has gradually been evolved-with the cries of victory, the wailing of women, the weird chant of the prophetess, or even the "hwyl" that may still occasionally be heard in Welsh pulpits. Where these have assumed a stereotyped form, as in the last-mentioned case, or in the Greek Pæan or Linus-chant, they may perhaps be considered analogous to the songs of such 


\section{34 Summer Studies of Birds and Books chap.}

birds as have developed a fixed phrase by which to express their emotions. And yet I doubt whether the analogy would be a very sound or useful one. As far as I can judge, there is in the music of the birds neither time nor rhythm nor scale; and these are the essential and primal elements out of which, together with tonality, our human music has been developed. What can be gained by painful attempts to express the songs of birds in terms of an art which has nothing in common with them except tone?

All efforts, then, on the part of ingenious persons to translate the language of the birds into their own are in my opinion lost labour, and can lead to no increase of our knowledge. But perhaps some one may object that they are no more lost labour than the birds' songs themselves, which may seem to be among those animal utterances which mean little and lead to nothing. Such an argument, however, would be wholly unfounded and unfair, for a bird's song has beyond all question both meaning and value; and though we cannot always be sure of the purpose it serves, we can at least arrive at some general conclusions on the subject, to be illustrated or corrected by the observation of every day. I will next take a glance at these conclusions-with the premise, however, that we are here, as indeed throughout this chapter, dealing with the true songs only, and not with the innumerable call-notes and alarm- 
notes which birds use to communicate with each other. The difficult question whether the true songs have or have not been developed out of these minor utterances I must leave for the present untouched.

Since the appearance of Darwin's Origin of Species there has been considerable discussion about the origin and meaning of song. In his great work, while developing his theory of sexual selection, the famous naturalist threw out a hint that the vocal powers of male birds might be explained on this hypothesis; and in his Descent of Man he worked out the idea more fully, and supported it by a considerable number of facts supplied him by books and correspondents. ${ }^{1} \quad$ The theory is, in brief, that the song of the male was developed as a charm to the female in the time of courtship; that the females usually select the best singers among their suitors to be their mates; and that thus, in the course of ages, the vocal powers have been steadily increased by the process of selection. The most highly-gifted birds are chosen as progenitors, and transmit their powers to their young; while the inferior performers are more likely to remain bachelors, exercising no influence upon the race.

The evidence which Darwin brought together in support of this view was by no means very strong.

1 Origin of Species, ed. 1888, vol. i. p. 70 ; Descent of Man, ed. 1, vol. ii. p. 51 foll. 
It was based chiefly on observations made upon birds in captivity - a kind of evidence constantly apt to be misleading. It is, in fact, extremely difficult to obtain really trustworthy observations as to the courting of birds in a wild state; even if we were to spend whole days in watching them from sunrise to sunset, their restlessness and locomotive power would make it very hard to prove beyond doubt that a given female selects the best singer among her wooers, nor could we feel very confident that the best singer in our judgment is also the best in hers. And Darwin, I think, was well aware of the doubtful character of his evidence; he records what bears against his theory with all his usual candour, and does not really press this part of his argument home. There are, however, two unquestionable facts which sustain his view. In the first place, true song is always a male character; if female birds sing at all, they sing, so far as seems to be known, a feebler and inferior song, which may be no more than a humble imitation of that of their lords. And secondly, the song of the male is at its best during the breeding season, and in many or most cases is heard at no other time. To these two facts we may add another, less cogent but very interesting, - that most of our best singers are very quietly-coloured birds; the inference here being that where beauty of plumage has not been developed to charm the taste of the females, another 
charm has been substituted in the form of highlyfinished vocal power.

It is to be noticed that this theory was primarily meant to account for the origin of song in birds, rather than its present meaning and use. I doubt whether Darwin himself would have maintained that all birds' songs are love-songs, or, as some less cautious writers will have it, that they are inspired only by feelings of rivalry and hatred towards other performers. It is, indeed, almost impossible for any one who lives all the year round among birds to accept the theory as an adequate explanation of song as it is now used by many species; and I should doubt whether it supplies us even with a sufficient reason for the primeval origin of song. With all my reverence for the great naturalist, I can hardly persuade myself that his view is here entirely in keeping with the general tenor of animal life, of which the force and spontaneity and enjoyment are surely not all derived from one set of emotions. In any case the field-naturalist must find himself continually confronted with facts which will raise questions in his mind about the theory of sexual selection, even if he should be unacquainted with the criticism to which it has already been subjected by eminent men of science.

While writing these pages in the country $I$ have many a time gone out for a stroll and heard the 


\section{38 Summer Studies of Birds and Books cHap.}

voices of several species of birds long after the natural period of pairing and nesting was past. Some of these birds, it may be argued, were having late broods; eggs may be found even in August. But a little watching will generally show whether this is so or not; and I am confident that it was not so with most of the birds I listened to. The most persistent of these is the Yellowhammer, who will go on singing throughout the summer, associating his monotonous strain with the sultriness of the unchanging August days. Yesterday it happened to me to drive some twenty miles through the country between Oxford and the Chilterns; and I may honestly say that on that last day of July there was a Yellowhammer singing in every hundred yards of open country through which I passed.

What can be the meaning of such persistence? Are these birds looking back regretfully to the happy courtships of last spring, or hopefully looking forward to fresh happiness in the spring to come? Or are they practising, as Darwin imagined,-practising with a view to outdo their rivals next pairing season? Surely this would compel us to assume that the mind of the bird, from February to September or later, is wholly occupied with thoughts of matrimony. To me it seems much more probable that when the young are grown up such thoughts are no longer in the mind of the parent bird, and that their place is 
taken by the immediate necessities and comforts of life - the abundance of food, and the gratifying warmth of the summer-until the time of moult.

Persistence in singing long after the breeding season is noticeable in some other birds, and is especially well known in the case of the Robin. The Common Wren, the Thrush, the Hedge-sparrow, the Chaffinch, the Great Tit, and a near relation of the Yellowhammer, the Corn-Bunting, will also sing the greater part of the year,-the first three in every month from January to December. Let us notice, by the way, that these are all extremely hardy birds, which stay with us throughout the year, and rarely, in our moist and fertile country, find themselves without abundance of food: for it may, I think, be taken as a good rule, that of singing birds those which are the hardiest and most easily supplied with food are the most persistent, if not always the best songsters.

Let us note one or two facts about two of these, the Robin and the Chaffinch. The Robin, indefatigable singer as he is, is not to be heard - or very rarely-in July and the early part of August. Seldom indeed will you see him at this time, unless you happen to be prying after some plant or insect in a wood, where you may surprise him in a forlorn state of moult, very indignant at being discovered in such a predicament. But no sooner is 


\section{40 Summer Studies of Birds and Books chap.}

the moult well over than he is on the move again, and again in song. And that autumn song is to me always peculiarly sweet and eloquent. It is the natural outpouring, I think, of high spirits and happiness, after a period of illness and change has been successfully passed. Sometimes it is accompanied with signs of love and courtship, and in a warm season these occasionally result in fresh pairing, and even in a nest and eggs. But I cannot believe that all the singing is here love-making; nor yet to be explained by animosity towards other males. I look on both singing and courting as equally flowing from the same cause-viz. renewed health and spirits and enjoyment. I remember once at Knaresborough, and again in Nidderdale three years ago, in fine weather, finding every garden and hedge echoing with the songs of Robins the first day or two of October; had all those songs meant love-making or quarrelling, I must have seen something more of it than I did. And they could hardly have meant mere practising; if constant listening to birds' voices can give one any idea of their meaning, then I think I have a right to say that those Robins were singing from pure enjoyment of the autumn sunshine, of the abundance of food and moisture, of fresh access of bodily health and comfort.

The song of the Chaffinch is familiar to every one whose mind has ever been occupied with these things. 
No bird insists on repeating the same phrase so constantly; and if its only object is to charm the hearts of the females, the hen Chaffinches must have a truly marvellous faculty for never-ending admiration of the commonplace. The males begin to practise their one phrase early in February, or even sooner; and ludicrous indeed are the efforts they make. These are partly, perhaps, the younger birds picking up the song from memory, partly the older ones whose strength is still hardly equal to the whole of it. For to sing is a great effort to a bird not in perfect condition, and even in the height of their spring vitality it is no small task for many of the slighter-built; it cannot be properly done when the bird is ill, or moulting, or underfed. And the Chaffinch, lusty as he is, even in the winter, is not equal to the strain until the sun has warmed him and brought him better food. I have known him sit on a bough by the hour together, hammering away at his song and tumbling over it in his clumsy efforts; but in two or three days he will usually have got it perfect.

When once this industrious practiser has accomplished it even to the last "twee-o," he is never weary of it. Few persons know how extraordinary his persistence is; had Darwin known, I doubt if he could have accounted for it either as practice, or as courting or rivalry. Both in England and on the 


\section{42 Summer Studies of Birds and Books chap.}

Continent I have counted the number of times this bird will sing his stereotyped song in one minute, and have always found it the same, viz. between six and seven times. Assuming that he begins at daybreak, he should sing it some five thousand times over in one day; and one fine morning last June I heard him begin it actually before sunrise.

I might mention other examples of the same indefatigable activity among our common song-birds, notably in the Skylark, which can hardly be accounted for by the theory of sexual selection; but I must turn to some other facts bearing on the same question.

Some birds delight in social gatherings, and in these, where there can be no thought of pairing or nesting, their excitement is expressed either by singing or some other kind of loud utterance. It is not often what may be called the true song of the bird, but it is certainly a vocal effort of the same kind, and deserves to be considered under the same head. These social gatherings will take place even in the breeding season; generally in the evenings after work is over, and when recreation is possible before sunset and roosting. Last June I used to watch and listen at a certain large osier-bed, in which a rare and interesting bird had then taken up its abode; and every evening the other birds seemed to be quite put to silence by the incessant singing,- 
not mere twittering, but real singing, - of some dozens of Swallows, which were careering about, now over the osiers, now far up in the air, the song now distant, now close at hand, until about nine o'clock they all suddenly dropped down into the osiers and were silent. That singing meant pure enjoyment of life-nothing more.

The Swifts, again, birds without true song, use their voices in this same way. Every one has seen and heard them dashing in little companies round the towers in which they build, and screaming with an intensity of enjoyment which quite communicates itself to the human looker-on. Rooks, as we all know, have mysterious habits, social and noisy, of the same kind. Even our unpoetical Sparrow, whose efforts at singing are of the meanest, will indulge of an evening in a sort of music-hall chorus, in which every bird chatters as loud as he can; hundreds taking possession of some favourite holly-tree or thick creeper, and joining in a discordant chorus just before roosting time.

These last two instances, it may be said, are not really cases of true song, though they are the substitute for it in birds which have their vocal organs developed but neglected. But I can quote a most remarkable example of real singing in company, without any reference to courting or rivalry. There is a large bird of the South American pampas, known 


\section{I44 Summer Studies of Birds and Books chap.}

to most of us in the London Zoological Gardens, for we hear his voice resounding over Regent's Park long before we reach the Gardens and find that he is the Crested Screamer. Mr. Hudson, in his Naturalist in La Plata, has a most interesting chapter on this bird, whose screaming, he tells us, is in its native country a powerful and magnificent song. These birds often sing all together in vast flocks at certain intervals during the night. Mr. Hudson describes an awful and overpowering burst of "melody" which saluted him from half a million of voices at an outof-the-way spot in the pampas one evening at nine o'clock; and again how once at noon he heard flock after flock take up their song round the entire circuit of a certain lake, each flock waiting its turn to sing, and duly stopping when the duty had been performed. It is indeed difficult to imagine that the voice of the birds in the Gardens could ever be the vehicle of real song ; but Mr. Hudson's account is explicit.

There are one or two other little facts which I must notice before I leave this part of the subject. Let us consider for a moment the singing of our Warblers -delicate birds which do not sing all the year or most of it, as do the Robin and the hardy ones I mentioned before. Here, if anywhere, we might expect to find the song exclusively used in the pairing time. Yet it is not so; the males arrive in this country some days before the females, and if it 
is warm and the sun shines, they will begin to sing at once; if it is cold and dreary, they will wait. You may hear a Nightingale or a Blackcap singing heartily but quite alone, not another bird of the species within half a mile of him. Such a solitary Nightingale sings in the parks at Oxford every spring. This may indeed be practice; and it further serves the purpose of attracting a mate, and as a rule succeeds : it may also attract other males, and then there is rivalry and perhaps fighting. But when the pairing is over, the singing goes on with almost as much vigour as before; and it is then used to divert and please the hen during the labours of nest-building and incubation, and also, no doubt, to keep her aware of his being close at hand. In one particular species, the Wood Warbler, it is especially delightful to watch the communications which pass between the male and female during the nesting time. As was pointed out to me by a most exact observer, the real song is then only uttered when the hen bird is on the nest: when she is off, its place is taken by a long-drawn call-note, far more beautiful in tone than the song itself; and the hen herself responds in notes similar in tone, but somewhat shorter and quicker. And I have read a curious statement by a good observer of the early part of this century, that the male Blackcap will sing even while taking his turn at sitting on the eggs, still keeping 


\section{I46 Summer Studies of Birds and Books chap.}

touch with his mate in this sweet and tender utterance. And indeed in my opinion song may be made to serve any useful purpose, according to the conditions in which a bird finds itself. It may even be an expression of anger at some intrusion or calamity. It is well known that you may make a Sedge Warbler sing by poking a stick or throwing a stone into the bush in which he happens to be. I have even known this bird sing vociferously its regular song, though somewhat loudly and harshly, while one of its young brood was being killed close by; for, unknown to me, my dog had seized this tender fledgling, and it was not till I discovered this that I discerned the meaning of the song. I have some reason to think that the Nightingale's song, which is of the same highly emotional type, is also sometimes used in this way; for Mr. Playne tells me that he has known a Nightingale sing loudly in a tree overhead while he was examining its nest in the undergrowth below. Again, while staying at a house near Newbury, I was taken by my host to see a Wren's nest in the thatched roof of a summerhouse, and was told that I should hear the cock bird sing immediately after every visit to the young with food. We sat some time in the arbour, and I found the account perfectly accurate. The female fed her young silently; but no sooner had the male left the nest than he uttered a distinct song,-a somewhat 
abbreviated edition of the strain we know so well. The object may have been to let his wife know that he had done his duty and that it was her turn next, or it may have been merely his way of expressing his own satisfaction with himself and his lot; but it had beyond doubt a meaning, and one in no way connected with courtship.

It is time I should sum up what I have been saying about the nature and objects of songs. I am inclined to think that in this particular instance Darwin was not in possession of a sufficient amount of evidence, and that his theory of sexual selection cannot by itself account for all we know about the singing of birds. Wallace, whose experience of living animals was larger, and perhaps more truly sympathetic, takes a different view. ${ }^{1}$ If I understand him rightly, he thinks that song is really only "an outlet for superabundant nervous energy," which natural selection has intensified and differentiated as being useful in many ways, among which we must certainly reckon the courting of the females by the males. Where vitality is not expended in producing brilliant colour in one or both sexes, it has been spent in producing brilliant song of a particular type and tone. This theory seems to me to account for the facts better than the other. It is in the main the same conclusion at which Mr. Hudson arrived in the

${ }^{1}$ A. R. Wallace, Darwinism, p. 284. 


\section{Summer Studies of Birds and Books crap.}

work I have already quoted. Having spent a great part of his life among living creatures on the pampas of La Plata, Mr. Hudson believes that singing and the other performances which he describes so well in his remarkable chapter on "Music and Dancing in Nature" are not the result of sexual selection, but are rather a perfectly spontaneous expression of délight or comfort, such as we may all feel at times, especially when we are young and have no great anxieties. The marvel of the best songs of birds is, indeed, their exquisite beauty and finish, and the steady adherence of one species to a particular typical strain. It seems to be otherwise with creatures that cannot fly. I have known young men whose animal spirits seemed to force them to make a noise-even to howl and scream-for no particular reason. So too with other creatures that walk upon the earth ; they low and bellow, and neigh and roar, in tones which are wholly inarticulate. But the birds are freer, sprightlier, brighter in their whole life ; their freedom and swiftness enable them to find food, water, and sunshine wherever they will; and this happier and keener life has in some of them developed a choice and beautiful way of giving vent to their joy. They have almost invented a language : their voices are not really inarticulate. Each species has its own tongue, in which the sexes dally and converse and communicate with each other; and 
this tongue is as a rule a beautiful one, because the life of the birds is itself beautiful-not only for the short time of courting, but beautiful and free all the year. It is the joyful life of the birds that has made their songs so grateful to us.

Let us now turn for a moment to yet another question. How do birds learn the peculiar songs and call-notes of their species, so that generation after generation keeps them up with little or no modification? This is a question on which our great naturalists seem to be fairly well agreed; ${ }^{1}$ but the evidence cannot be said to be very extensive or complete, except for caged birds, and it is curious that most of the experiments that have been made with these date as far back as the last century. Daines Barrington, the friend of Gilbert White,- the same man who a few years earlier had reported to the Royal Society on the extraordinary natural gift of a great human musician, then the child Mozart, recorded in 1773 a number of experiments with young birds; and his notes form the staple of the evidence used both by Darwin and Wallace. He came very decidedly to the conclusion that birds learn their song by imitating their parents' voice; and that if you take them early from the nest, and place them near other birds, they will imitate these instead. If you put them to school with a single

1 Wallace, Natural Selection (ed. 1891), p. 104. 


\section{50 Summer Studies of Birds and Books cHap.}

bird, they will acquire that' bird's song, and if with birds of two or three different species, their song will probably be a mixture. But when once a lesson is thoroughly learnt, it seems to be rarely forgotten: they will not desert one song and take up another, however often they may hear it.

These experiments of Barrington's, and some others also, do undoubtedly prove that even if birds have an hereditary tendency to sing the song of their own species, it may be easily overcome, and bent in another direction, by placing them within hearing of the songs of other birds. But I cannot help thinking that the subject needs more careful investigation, and that there are difficulties which are not yet cleared up. For example, how does the young Cuckoo learn the note of his own species? He is brought up in an alien nest, and hears the song and the alarm-notes of his foster-parents. Some say that the parent Cuckoo continues to feed the young bird, and haunts the nest for some time, though that has not been the case within my own experience. If that be so, it might be argued that the young Cuckoo, whose voice organ is not, I suppose, suited to produce the notes of a Tree-pipit or Wagtail or Dunnock, naturally imitates the voice of its true parent. But there is again a difficulty: by the time the young bird is hatched, the old Cuckoos are rarely heard, and have in any case lost the true intonation of their song. 
And why should it not equally well imitate the cawing of Rooks overhead, or the cooing of Wood-pigeons, and any other notes of full-voiced birds to be heard round about? How is it to recognise and imitate, among all these, the voice of its true parent?

And I might put another case of this kind, to show that the difficulty is a real one. Suppose a Nightingale has a nest at the roots of a tree; when the young are hatched the cock bird ceases to sing, and devotes himself to feeding them. Now, there may well be a Willow Warbler, a Blackcap, or a Garden Warbler still in full song hard by,-it may be in the very same tree : why then do not the young Nightingales learn the song which is thus poured into their ears all day? We might at any rate sometimes expect to hear wild birds with a mixture of song, derived from those of other species ; and yet, in the great majority of birds at least, the song is fixed, stereotyped as it were, and only alters here and there dialectically, not by the reproduction of the songs of other birds.

These are difficulties which make me hesitate to accept too readily the theory that the songs are acquired simply by imitation of the parent. Of course if we could take a nestling from the nest before he has heard the parent sing, if we could keep him away from all birds' voices, and if we then found that he adhered to the parental song, or, on the other hand, if we found that he could not sing at all, 


\section{52 Summer Studies of Birds and Books cHap.}

the problem would be solved. But this experiment would, I think, be as impracticable as the one which Herodotus ascribes to the king of Egypt who shut away two infants from all voices, to see what language they would speak. The nearest approach to such a case that I have met with is recorded by Mr. Hudson. He tells us that he once observed a tame Tinamou (a bird of the pampas) which had been taken from its parents just as it had issued from its egg, and which was still only half-grown, yet sang the song of its own species perfectly for an hour together every evening. With large birds of this kind the experiment is possible, because they can run about and feed themselves directly they break their shell; but the young of our song-birds cannot do so, and it would be almost hopeless to try and keep them alive out of the nest when only a day or two old.

All that I am contending for is that there must be an inherited tendency in birds to learn easily the songs of their parents. That they do readily imitate, and even that they are, in some cases, carefully instructed, I can hardly venture to doubt. Not long ago a lady wrote to me from Rome a very explicit and apparently truthful account of a lesson given by an old Nightingale to a young bird, at which she had herself been present. She said that the teacher repeated each phrase until the pupil had it perfect. ${ }^{1}$

1 See below, p. 189. 
Curiously enough, the idea that the Nightingale teaches its young to sing is as old as Aristotle. He says in his Natural History that this bird "seems to instruct her young ones, and to repeat to them certain passages for their imitation, as the language does not come naturally in the same manner as the voice, but must be acquired by exercise and study." And once more we have a capital instance from $\mathrm{Mr}$. Hudson of the pains which young birds will take to acquire their song. He says that the young of the Oven-bird, when only partially fledged, are often heard practising in the nest or oven the curious duets which the parents are in the habit of singing together. This goes on while the old birds are absent; "single measured notes, triplets, and long concluding trills are all repeated with wonderful fidelity."

While we are upon the subject of imitation, I should like to say a word about that very curious phenomenon in a few birds - the intentional and impudent appropriation of the notes and songs of others. I do not know that I can explain this, but I can at any rate give a good example of it.

We have all heard of Mocking-birds, but few of us probably have heard the feat accomplished to perfection. We have one or two common birds in England which attempt it - the Starling, for example, and the Sedge Warbler. This last little bird is clever at mimicking, in the course of his incessant rattling 
I 54 Summer Studies of Birds and Books crap.

song, the call-notes of certain species which are always in his neighbourhood-e.g. the Chaffinch, and the Pied and Yellow Wagtails. He is often said to go further than this, and to reproduce complete songs; but this I have never heard, though I have listened to thousands of Sedge Warblers. But the Marsh Warbler, whose performances I have described in another chapter, is probably as skilful a mimic as any bird in the world. I have many times listened by the half-hour together to his wonderful and amusing song, which has quite an individuality of its own, and is of the same general type as the Nightingale's; but a great part of it is taken up with most unmistakable and sometimes quite ludicrous robbery of other birds' strains, so that I, who had always been a little sceptical about the accounts of mocking-birds, became at once and for ever convinced.

It is hard to say why this particular species, and so few others, should have taken up with this thievish propensity. Why is it that its near relation the Reed Warbler, a bird in outward appearance almost exactly like it, should lead a perfectly sober life, and steadily recognise the difference between meum and turm? The only suggestion I can make is, that of the two the Marsh Warbler is far the more vivacious, restless, and apparently full of fun; and that, while the Reed Warbler represents the conservative element which is so strong in bird-life-the 
leading principle, one might say, of a bird's mind,the Marsh Warbler is the radical in the genus Acrocephalus, with an irresistible desire to push into fresh experiments and innovations in song, and to appropriate freely the gifts and inventions of his neighbours. Or, in sober language, the nervous intensity of some birds is certainly greater than in others; and these are often the most vivacious singers. If they have developed no very definite form of song for themselves, it may be that their excitability leads them to imitate others. And as it is really from the mental constitution of our own species that we can learn most about that of animals, it may not be out of place to remark that it is exactly the brightest, quickest, most fun-loving among human beings who are most prone to imitation and caricature.

While I am on this subject of mimicry in song, it may not be amiss to advert for a moment to a theory lately propounded in the Zoologist, ${ }^{1}$ which would explain all songs as imitations, either of the utterances of other birds, or of inarticulate sounds which are constantly obtruded on the bird's ear. The writer of these articles has made a most painstaking analysis of many of the best-known songs; his perseverance is admirable, and it is only in his conclusions that he seems to have let his fancy run away with him. He suggests, for example, that the Song-thrush began

1 For 1890, pp. 233 foll. 
by imitating the sound made when a snail-shell is being broken against a stone; from this humble beginning, used perhaps as an invitation to others to come and feast on snails, it has gradually developed its splendid song. The Swallow's note resembles the sound made by the breaking of the wing-cases of beetles; the harsh tones of the Rails suggest the crushing of the tender shells on which they partly subsist. But one Rail, the Corncrake, has a still stranger origin assigned for its familiar double crake: it took a fancy to imitate the noise made by a cow in browsing, whose big rough tongue rasps up the grass, first on one side of the mouth and then on the other, producing a kind of rhythmical cadence. The Starling's "whining" sounds are like the noise made when a bird pulls a large worm out of the ground. The Wood-wren's song reminds this writer of the sound caused by the two branches of a tree rubbing against each other. The Robin's song is like the gurgling of water, says Mr. Witchell; and adds, "The Robin is frequently found near water" !1

Surely it is hopeless to try to discover the ultimate origin of individual songs. It is little or no good to publish mere guesses which cannot possibly

${ }^{1}$ See also an interesting paper on "Bird Song and its Scientific Value," in the Proceedings of the Cotteswold Field Club, which Mr. Witchell kindly sent me. I so fully appreciate the value of his observations and records, that I much regret having to differ from the conclusions he has based on them. 
recommend themselves to the judgment of cautious inquirers. It would be more possible, and on the whole more useful, to examine a single group of closely-allied songs, with the object of finding in them some common ancestral element-an archetypal song, the character of which has survived throughout the genus, while particular species have been gradually varying and modifying it. As song is without doubt a valuable specific character, it might surely be worth while to trace its relation, as well as that of plumage and structure, to the generic characters of the whole group. Take, for example, the songs of the Buntings; they all resemble each other very closely-those at least with which I am personally acquainted. They consist of a quick succession of notes, varying slightly in tone and pitch with different species, and possibly developed from a primitive sound indicating invitation or alarm; but one or two species have added to these quick notes others which are longer and more musical, and which transform the utterance into something more like a musical phrase. The Yellowhammer has done this with one note, the Reed Bunting with several, the Corn Bunting with a melancholy wheeze, which may some day grow into a pleasant sound; but the Cirl Bunting and the Meadow Bunting (Emberiza Cia) have added nothing to the quick notes as yet, and seem rather to have devoted themselves to improv- 


\section{58 Summer Studies of Birds and Books cHap.}

ing the tone of these, than to inventing new ones to add to them.

I am tempted to pursue this subject, but it is a difficult one, not only to investigate, but to deal with on paper in any shape. I will be content with one remark and one illustration. It has often struck me as strange that the songs of closely-allied species should in many cases be so very different from each other-those, for example, of the Willow-wren and Chiffchaff, or of the Common and Lesser Whitethroats. Yet close and attentive listening has in some cases convinced me that there is really a common element, which might easily be missed by a chance hearer. The song of the Common Whitethroat is a kind of lively and rather jerky warble, while that of the Lesser Whitethroat is a succession of loud resonant notes, all of exactly the same high pitch ; the two songs, in fact, appear to be as specifically distinct as they can well be. But place yourself quietly under a tree in which the lesser bird is singing in May, and you will hear a subdued introduction to that series of loud notes, which to my ear is the same in character as the song of the larger species. If I am not mistaken, this is a survival or reminiscence of the generic Whitethroat song, to which this species has appended a striking musical invention of its own. It still needs a considerable effort to produce this new music, and the effort is not invariably successful. 
One cold and rainy day last May I had proof positive of this. There is a spot in the parks at Oxford where this bird settles himself every spring, and sings with all his might every fine morning. That day, in the usual place, I heard what for the moment I took to be the warble of the other species; but after hearing it again I began to doubt my own conclusion. In another minute the song was repeated, with two or three of the familiar loud notes following it ; but the effort was too great, and the little bird collapsed before he had completed the performance. The weather was against him, and his heart was not in the work. I may add that I have even heard the Willow-wren begin his song in a manner that strongly reminded me of the Chiffchaff; this was just after his first arrival in spring, when he was perhaps still suffering from the fatigues of the journey. The song of this bird, like that of the Chaffinch, increases greatly in power as the days grow warmer.

One word more before I close this chapter. My readers may possibly care to know which songs have affected me most during the many years since I first learnt to distinguish them. It is, indeed, hardly possible to dissociate a bird's song from its surroundings; and the Robin in November, the Blackbird in February, the Dipper by a trout-stream, or the Chiffchaff's ringing notes in March, all have a special charm of their own which is not derived solely from the melody 
of the bird. But, apart from such associations, I should unhesitatingly endorse the general verdict of mankind, and place the Nightingale at the head of all songsters. There are, indeed, Nightingales and Nightingales; but when I listen, whether by day or night, to a grand singer in the height of his powers, with his heart full and his health perfect, I feel a sense of wonder, nay of awe, with which no other bird inspires me. That long sweet crescendo, unique among all birds, that liquid trill of marvellous sweetness, that swift and sudden cadence, followed by a long mysterious pause-what a mind, what a love of art one might almost say, must a creature have who can invent and delight in such sounds, such startling effects as these! The Robin is one of our most beautiful singers, and in point of variety I doubt if any bird can rival him; but when. I once heard a Robin try his song in a tree above a thicket where a Nightingale was singing, his whole tone paled before the fire and intensity of the master,-and he seemed to recognise it himself, for he almost immediately departed.

Next to the Nightingale many would place the Blackcap; and the music of his song, if he is at his best, is wonderfully sweet and pure, though he never gets beyond one simple form of strain. But in splendour at least of performance, I am inclined to place the Skylark second. Fully to appreciate the 
wonderful powers of this bird, you must watch him from his first leaving the ground, on a sunny morning, and follow him up into his "privacy of glorious light," abstracting your mind from every other sound, and gathering in the full force and sweetness of that incessant strain. There are many strident notes in it, but the higher he rises the softer will it fall upon the ear, while every note still remains as clear and resonant as it was at first.

Hardly less delightful, though far less familiar, is the song of the Woodlark. Rarely indeed does it happen to me now to catch the voice of a bird unknown to me; and I am not likely to forget how I was saluted, while strolling in the garden of a Welsh farmhouse in the early morning of the 30th of March this year, by a clear and liquid song repeated at short intervals from a tree hard by. For a moment it reminded me of the Great Tit; but other strains followed, which I might compare to those of the Skylark, the Nightingale, and the Lesser Whitethroat. As I grew accustomed to the song, which was repeated daily while I stayed there, I fully recognised its individuality, and should hesitate to describe it as imitative. It was a song to refresh and invigorate you; and the performance suited well with the freshness of early morning among the hills, and with the murmur of the trout-stream beyond the meadow.

There are yet three singers, each of whom might 
well be placed first for some special gift of tone or expression. The Blackbird is unrivalled in beauty of tone, but he has never learnt to use his instrument with perfect finish; he seems to be constantly practising, as I have always fancied, and as $\mathrm{Mr}$. Burroughs too remarked when he first made acquaintance with our English birds; but perhaps we love him all the better because those native woodnotes are so artless. The Song-thrush is a finer artist-a brave and spirited performer on an instrument of noble quality. And the Robin, with his peculiar tender pathos-so at least it seems to us,-is also the great master of variety; listen to him intently for a quarter of an hour, and you shall hardly hear the same phrase twice over. With these one other common bird deserves to be classed-that gentle and graceful Tree-pipit of whose song I never tire; and then we have a dozen others to all of whom we may be duly grateful, though none of them, in force, in richness of tone, or in profuseness and variety of strain, can altogether rival those I have selected as being in my judgment the true kings of song. 


\section{CHAPTER VII}

\section{ARISTOTLE ON BIRDS ${ }^{1}$}

ALL associations, all universities for example, and all colleges and schools, from time to time perform the welcome duty of celebrating the memory of their founders and benefactors : a duty to which it is all the more important to attend, because we are all of us so liable to forget the debt we owe to those who have spent their labour or their wealth to make us what we are. We are obliged to spur our memories from time to time by these wholesome ceremonies, to save ourselves from forgetting how our association came into existence, and to whom it owes its life and all its successful work.

I am going to speak this evening of one who may not inaptly be described as the founder and the benefactor of all Natural History Societies. It is a bold step to take, for I shall have to carry you back to a period more than three hundred years before

1 A lecture given to the Natural History Society of Marlborough College, November 1887. 
the birth of Christ, and to writings which are by no means easy to deal with in the limited space of an hour. But I am tempted to try the experiment, for a great part of what Aristotle wrote about natural history is still extant-sufficient at least to show us not only that he was the first naturalist of whom we have any record, but that he was a really great naturalist, with far-reaching views of the whole subject, and with infinite perseverance and curiosity in collecting facts and details. His defects are, indeed, obvious enough; we can see that he did not care, or had not time, to sift the evidence for many facts reported to him, and that he mixes up fact and fiction in a very bewildering way. But if we try and judge him, not by our own standard of knowledge and criticism, but by that of an age when what we call science was hardly yet born, we shall revere him as the first man who set himself to collect the facts of animal life, and to explain them so far as he was able.

It must be allowed, indeed, that his influence on the study of natural history in the ages that followed him was not entirely a wholesome one. So great was the power which his vast learning, his exactness, and his evident conscientiousness exercised on the minds of men for eighteen centuries, that naturalists - if I may use the word of them-were content to follow him alike where he was right and 
where he was wrong; and during all those centuries hardly any progress was made in our knowledge of the world of plants and animals. No one thought of making a fresh start by using his own eyes and collecting his materials independently of all books. Even the great Pliny is no exception to this rule in his zoological studies; it is told of him that he once scolded his nephew for taking a walk when he might have used the precious time for reading. All through the middle ages we seek in vain for a true naturalist; it is only when the revival of learning and the reformation of the church had freed men's minds from the tyranny of books and traditions, that at last we find such men as Gilbert and Bacon and Galileo beginning to interrogate nature for themselves. How incredible it seems to us in these days that not a single monk-not one in all those splendid monasteries that swarmed all over England-should have been inspired to write such a book as that of Gilbert White! What would we not give for an exact record of the plants, the birds, and beasts which were to be found six centuries ago around Fountains, or Rivaulx, or Netley, or Abingdon !

This darkness is in some degree to be attributed to Aristotle, though he himself would have most deeply deplored it. He would have recognised how hopeless it is to abide content with the learning of 
previous explorers; how necessary to be continually testing with your own eyes what others have recorded in books. He would have delighted in the labours of two such men as our countrymen Ray and Willughby, who in the seventeenth century initiated a new era in the study of plants and animals; and still more would he have rejoiced in the great comprehensive work of Linnæus in the century which followed, and in the minute and patient observations of White of Selborne. Between Aristotle and Linnæus, a period of more than two thousand years, there was indeed no great and universal naturalist; and down to the time of Darwin, these are the two greatest names in the history of natural history. Each of them had a definite function to perform. Aristotle gathered together the current knowledge of his day, and added to it largely by dissections and observations; he first directed attention to the facts and mysteries of animal life. Linnæus' work was classification, a task which could not indeed be then adequately performed as we demand it now, but one which had to be performed in some fashion before further advance could be made. To these two men, more perhaps than to any others, we must look back as the founders and benefactors of all Natural History Societies.

Aristotle lived in an age when thinking men- 
and thinking men were then almost entirely Greeks -were beginning to feel what we now call the scientific spirit; that is, the desire to know exactly what happens and exists in this world of ours, and why it is so. The Greeks, in whose prose and poetry we chiefly delight, nearly all of them lived and died before Aristotle; they belong, not to the age of scientific inquiry, but rather to an age of art, and faith, and fancy, when men delighted in what they saw around them, and took it all for granted, without troubling themselves with questions about its nature and its cause. Where they did inquire, they inquired in such a vague and general way, that in regard to the secrets of nature they often rather mystified both themselves and their pupils. This was the way of Greek men of intellect down to the middle of the fourth century B.c.; i.e. down to the time when Philip of Macedon was beginning to build up his mighty power, so soon to overshadow and to overwhelm the bright Hellenic race.

The father of this Philip of Macedon had a Greek physician of great repute; and the son of this doctor, who was therefore much the same age as Philip himself, was Aristotle. The place where the family lived was a Greek town on the north coast of the Aggean Sea; and here, with ample opportunity for indulging a boy's love of bird and beast, the young Aristotle lived his early years, helping his father in the surgery and labor- 


\section{68 Summer Studies of Birds and Books chap.}

atory, and destined for the same profession, which is said to have been hereditary in the family. If you look at a good map of Greece, you will see that this little town of Stageirus is placed in a most favourable position for a naturalist. It lies on a sea abounding in fish; above it rise the wooded heights of the eastern coast of the Chalcidic peninsula on which it stands; only a few miles distant is the river Strymon, which was so famous for water- and marsh-loving birds, as to give its name as a perpetual epithet to at least one species. Straight across the sea from Egypt and the Soudan came, and still come every spring, multitudinous armies of migrating birds; they rest awhile about these rivers of the Thracian coast, and then pursue their way northwards, crossing the Balkan Mountains into the plains of the Danube and Russia, to return again in the autumn. And of course for an inquiring naturalist a seaport town is always a desirable place; for here come sailors from foreign lands with tales of strange birds and beasts and plants, specimens of which they sometimes bring home with them. We may be sure that the physician, Aristotle's father, made use of the sailors to increase not only his pharmacopœia, but his knowledge of the world and its contents; and we may be sure that young Aristotle too was quick to profit by these chances.

But a boy with a mind like Aristotle's was not 
likely to be content to remain at home to work the pestle and mortar. He had that wonderful thirst for universal knowledge which seems to be getting rarer as the field of knowledge itself grows wider and more accurately worked. It was only a small part of his ambition to know about plants and animals; he wanted also to know about man, the nature of his mind, his sense of right and wrong, and the way he gathers into states and lives under various forms of government. There was but one city in Greece where studies like these could be effectually followed-the city where Plato was teaching, and where every young Greek who really wished to learn was certain sooner or later to find himself. It was when he was about twenty that Aristotle first went to Athens. There he attached himself to Plato's school, caught the spirit of the great master, and began those philosophical works which have more especially made his name immortal.

It seems probable that Aristotle wrote the greater part of his book on animals in early life, before he gave himself up to the higher influences of philosophy. But, like all or most of his works, it was not finished and rounded off all at once. He knew very well that a good book on such a subject cannot be turned out in a moment like a table or a chair; it must be continually growing, as additional knowledge comes to its author. Throughout his life, which lasted 


\section{70 Summer Studies of Birds and Books chap.}

forty-two years after his first arrival at Athens, he was gathering more knowledge and adding it to his book, or correcting, or perhaps striking out. It can be quite plainly seen, from the text as we have it, that additional notes were constantly put in, and that the whole work was never finally completed. We may suppose that the process of completion was going on all the time that he spent chiefly on mental and moral philosophy. Quite in the last years of his life, long after he had been called back to Macedonia to become tutor to the young Alexander the Great, and had seen his pupil mount the throne and depart for his expedition to the East, it is said that he was provided with money by the King for his researches, and that the officers of the Macedonian army were ordered to send him specimens, and to help him in every possible way to carry on his work. ${ }^{1}$ We cannot be sure how far this is literally true, and we may be pretty certain that another story, which tells how Aristotle himself went with that famous army to Asia Minor, Syria, and Egypt, is not to be credited; but it is quite probable that his old pupil, who loved and reverenced him, at least until the last few months of his life, should have used his unrivalled opportunities to satisfy the old man's unlimited curiosity.

The work which thus took a lifetime, in all prob1 Plin. $N$. H., viii. 44. Athenæus, $398 \mathrm{e}$. 
ability, to put together, consists of nine books. The first is about animals in general, their habits of life, food, and so on; and here man is treated of just like the rest of the animals. The second is about the outward structure of animals containing blood. The third deals with their minuter parts, the tendons, fibres, hair, veins, etc. The fourth treats of the organs of crustacea, echini, etc., about which the author is extraordinarily well informed, and also about insects. The three next books work out more fully the same subject-the organs of various kinds of animals-and it is only when we come to the last two (the eighth and ninth) that we begin to find what we in these days call natural history proper, i.e. some account of the ways of life, the different kinds, the various affections, the instincts and reasoning powers, of bird, beast, and fish. These two books are, therefore, those from which I shall chiefly draw what I have to tell you to-night.

It would, indeed, have been almost impossible for any one at that time to have written a real natural history of any class of animals, for at least one very good reason: classification, scientific names and terminology were unknown. And here we have an excellent opportunity of learning a lesson about the necessity of scientific names, and of realising the advantage we enjoy in having this already accomplished for us. Try to put yourselves in the position 


\section{I72 Summer Studies of Birds and Books chap.}

of a man who, like Aristotle, wished to deal with all kinds of animals, yet had no means of distinguishing them, except the common names which country folk had given them. Of course there were many rare or out-of-the-way species which had no names at all; and thus we find Aristotle often obliged to describe them as best he could without a name at all. Then remember that one name is not enough to enable us to be sure of the particular kind meant. It is only since the universal application by Linnæus of the principle of the double Latin name that we have been enabled to know with tolerable certainty what species is referred to by a writer; and even now the difficulty is often so great that it has lately been proposed to adopt, in certain cases, a system of three names. Let us consider this point for a moment, in order to understand the chief difficulty that Aristotle had to contend with, and to appreciate the curious fact that for two thousand years after his time natural history remained a hopeless chaos. ${ }^{1}$

Supposing you wished to find a book in a large library to which there was no catalogue. If the books were arranged in some order-the poets together, the historians together, and so on-you would

1 To illustrate this confusion I may quote the heading of Willughby's account of the Bar-tailed Godwit (ed. 1678, p. 292) :'The Godwit, called in some places the Yarwhelp or Yarwip, in others, the Stone Plover. The Barge, or Egocephalus of Bellonius as I take it. An Fedoa Gesneri? An Rusticola Aldrovandi?" 
have a fair chance of finding your book if it were there; but if there were no such arrangement, you might be wasting your time and temper for half a day before you chanced upon the one you wanted. By far your best chance would be if the books were so ordered that, e.g., one whole case contained poets, and each division of that case contained poets of different kinds, dramatic, lyric, epic, etc., and each shelf in each division contained poets of different languages ; so that if you wanted to find Shakespeare you would look, in the case of poets, in the division for dramatic poets, and in the shelf for English dramatic poets. Since Linnæus the library, so to speak, of natural history has been ordered and classified in a system something like this. There is a case for birds, there are divisions for the chief orders of birds, and shelves for the minor distinctions of birds, and each case, division, and shelf has its name allotted to it in a language which all the learned world can understand, i.e. Latin; and for common convenience the names of the divisions and the shelves-by which I mean the generic and the specific names, the two most useful working distinctions in dealing with one kind of animal only-are taken to denote, to be the full scientific name of, each individual species.

Thus just as you say that a book will be found in division A, shelf 6, so you call a bird Fringilla coelebs, i.e. you mean a bird belenging to the genus 
I 74 Summer Studies of Birds and Books chap.

Fringilla, or Finch, and to the species coelebs, which all naturalists recognise at once to mean the Chaffinch. If we had no other name but Chaffinch to give it, it would be hopeless to try and make any one but an Englishman understand what we mean; and indeed there are millions of English people who would not recognise it by that name. They would probably know the bird if you called it a Twink; but even then you could not be certain that you had conveyed to them the idea of the right bird, because the country people are apt to call other birds besides the Chaffinch by this very old and favourite name.

Now Aristotle was just in the position of a man who wants to tell people what books there are in a great collection, which is scattered in confused piles over the floor of an immense room, without any shelves to arrange the books in. Those shelves, i.e. the names, were not made for another two thousand years; and it is perhaps doubtful if they could have in any case been easily made without the aid of the Latin language, which was at that time still in a rude and semi-barbarous condition. And I suppose this is partly why Aristotle preferred the study of the physiology of animals to that of their classification and description; and certainly this is why it is often so very hard for us to follow him when he speaks of individual species. He notes, perhaps, a few par- 
ticulars and habits, but he gives us only the common Greek name; and in the case of any ordinary little brown bird that has not some striking peculiarity in bill, or tail, or claws, he leaves us, of course, altogether in doubt as to the particular species he means. In fact, I could not possibly have ventured to come and speak to you about him and his birds this evening if a learned ornithologist, the Swedish Professor Sundevall, had not been at the pains to bring to bear on Aristotle his knowledge of Greek, as well as his knowledge of natural history, and so saved me an amount of trouble for which I never could have found time. ${ }^{1}$

Let. us now turn to Aristotle's account of the birds; and in the first place let us see what he says of their numbers and habits. It is surprising at first to find that he mentions no less than 175 different kinds ${ }^{2}$ - species we can hardly call them with certainty, because the distinction between genus and species was then of course unknown, and old naturalists, just like country folk now, were always liable to confound species together and call them by

1 The Clarendon Press is about to publish a Glossary of Greek Birds, by Prof. Darcy Thompson of Dundee, a scholar as well as a zoologist. As I have been privileged to see some of the proofsheets of this work, I am able to say that it will contain the most exhaustive treatment of the subject that has as yet appeared. Sundevall's book is Die Thierarten des Aristotles: Stockholm, 1863.

${ }^{2}$ So Sundevall : others reduce it to 150 or less. 


\section{I76 Summer Studies of Birds and Books chap.}

one name. Aristotle's 175 would be a most creditable proportion for an age when an ornithologist had neither gun to shoot with nor field-glass to spy with. In fact it is interesting to conjecture how he can have contrived to make his list so large. By way of explaining this, I will remind you, in the first place, that birds are more obvious to the unassisted eye than any other animals, because they are always moving about, and attracting our attention by their voices; secondly, that they-or at least certain kinds of them-have always been of peculiar interest to uneducated people, who imagine them to have some prophetic power, some influence over the fate of human beings. Thus the Romans were always on the look-out for signs from the birds; and there are still people who will gravely take off their hats to a Magpie. Those who attend to such things, too, are well aware that the ways of birds are really of some value in warning us of the changes of the weather-Swallows fly low, Gulls come inland, Rooks tower, Pigeons fly wildly about, when a storm is approaching. Virgil tells us of such signs in his first Georgic; and Virgil himself drew much of this Georgic from a Greek poem by Aratus, the subject of which was the signs of the weather: a poem which contains a great deal of curious lore, and shows, as well as the poetry of a much older Greek, Hesiod the Bøotian, that the Greeks-as well as 
the Romans-were in the habit of attending to the prophetic properties of the birds. Thirdly, we must not forget that, in spite of their reverence for them, neither Greeks nor Romans ever scrupled to eat them, and in fact to eat a much greater variety than we sacrifice to our appetite for game. We learn from Aristophanes' comedy of the Birds that there was a bird market in Athens, just as there is a bird market in modern Rome, "where," says Waterton in his Autobiography, "I often counted over four hundred Thrushes and Blackbirds, above one hundred Robins, with twice as many Larks, and other small birds in vast.profusion." In an Italian book on natural history, drawn up for the use of schools, I found that the part about birds began with a description of the various ways of catching them! Robins on toast are said to be a favourite dish in Italy. Whether the old Greeks went so far I cannot say; but at any rate the Greek was an enemy to birds, for Aristophanes makes the chorus in the Birds (which consisted, by the way, of twenty-four different species) sing of man as

"An impious race

Which was ever one to me

Bred in mortal enmity

Since it first began to be."

And Peisthetærus tells the chorus that 
"The cunning fowlers for you set

Snare and springe, twig, trap, and net,

Catch and sell you by the score;

Buyers feel and pinch you sore." 1

Aristotle, then, had plenty of opportunity of procuring specimens of birds, either alive or dead, during his long stay at Athens, and also of getting information about them from the fowlers who brought them to market. In his description of the habits of the Partridge, for example, not only does he quote the bird-catchers, but it is plain from the account itself that no one but a professional could have supplied him with the information. ${ }^{2}$

What, in the next place, does Aristotle tell us of the habits of birds in general ? What, for example, does he tell us about migration, the greatest of ornithological problems? Let me remind you that even Gilbert White only a century ago could not quite persuade himself that some birds do not stay and "lie low" in the winter. Writing in 1793, he has, he says, "great reason to suppose that the Sand-martins do not leave their wild haunts at all, but are secreted amidst the clefts and caverns of those abrupt cliffs where they usually spend their summers." Now here is a note of Aristotle's on migration, which will

1 Aristoph. Aves, 526 foll.

${ }^{2}$ Hist. Anim. ix. 8. The references are to Bekker's edition of 1837. 
show you that he had got at least-as far as the sage of Selborne :- "All animals have a natural sensitiveness respecting heat and cold, and like men who seek cold places in the summer and warm places in the winter, so animals, if they can, migrate from place to place. Some are indeed always resident in their accustomed places; but others migrate, flying from the approaching winter at the autumn equinox, and at the spring equinox returning to the colder countries from dislike of the heat. Some migrate but a short distance, others, e.g. the Cranes, come from the ends of the earth; for these travel from the plains of Scythia (i.e. southern Russia) to the marshes of Upper Egypt whence the Nile flows (i.e. the Soudan). There the Pigmies are said to dwell; and this is no fairy-tale, but there is in reality a race of little men and horses who live in holes in the earth. The Pelicans also migrate, and fly from the Strymon to the Danube, where they breed. . . . The fish also migrate, some into the Black Sea and back again, some in the winter from the deep sea to the land, seeking the warmth of the shore, and vice versd. The weaker kinds of birds too descend in winter and frost to the plains for the sake of warmth, and return in the summer. . . . The Wood-pigeon and Stock-dove leave us, and do not winter with us; and so does the Turtle-dove; but the Rock-dove stays with us all the winter. The same is the case with the Quail, though 
a very few 'Turtles and Quails may remain behind in sunny spots." He then gives some particulars of the migration of quails, which was well known owing to their excellence as food, as it is still on the Mediterranean coasts; and then goes on to mention many animals which hibernate instead of migrating, e.g. the snakes, snails, and many insects. ${ }^{1}$ Then, returning to birds, he proceeds :- "Many kinds of birds also hibernate, and they do not all of them go, as some imagine, to warm countries. . . . For many Swallows have been seen in holes almost stripped of feathers, and Kites have been known to come out of such places when they have first shown themselves. The Stork, Blackbird, Turtle-dove, and Lark hide themselves; and by general agreement the last most of all, for not one is said to have been seen during the winter." 2

Here, though Aristotle was wrong in supposing that any birds hibernate, i.e. lie torpid in winter, it is remarkable to find him telling us that there were some Greeks who were right on this point; and on the whole his knowledge of the movements of

1 H. A., viii. 12.

${ }^{2} H$. A., viii. 16. The loss of feathers by hibernating birds is asserted by Aristotle more than once: cp. of the Turtle-dove in this same chapter. In Nature, vol. xlv. p. 416, Mr. A. H. Macpherson drew attention to the similarity of these statements and that relating to a captive Cuckoo hibernating in a kitchen, described in Nature, vol. xliv. p. 223. 
birds and fishes is most surprisingly large. And it surely is not wonderful that he and all other old naturalists should have fallen into this error about birds, if we consider that it was but a guess, based on their knowledge of the ways of bats, snakes, and other hibernating creatures. I think it is only fair to Aristotle to compare him in this matter with the best of all our early English ornithologists, Francis Willughby, whose book on birds was edited after his death by his friend Ray, in 1678. He says : "What becomes of Swallows in winter-time, whether they fly into other countries, or lie torpid in hollow trees, neither are most historians agreed, nor can we certainly determine. To us it seems more probable that they fly into hot countries, Egypt, Ethiopia, etc., than that they lurk in hollow trees, or lie in water under the ice in northern countries, as Olaus Magnus reports." And then he quotes Herodotus and Peter Martyr to bear him out. You see that Willughby has good sense, but has not got much further than Aristotle. And it must be allowed that Aristotle does not tell us, as Willughby does, that "a Swallow's nest heals the redness of the eyes, and is good for the bite of a viper"; nor that one hundred Swallows, with an ounce of castor-oil, and plenty of white wine, are an admirable medicine for the falling sickness. ${ }^{1}$

There is another affection to which birds are 1 Willughby's Ornithology, ed. 1678, pp. 211, 212. 
subject-the moult. Before we go on to glance at Aristotle's accounts of species, let us see whether he has anything to tell of this. It is not, of course, to be expected that we should find him explaining, as the modern ornithologist does or ought to do, the variations of plumage assumed by birds at different seasons of the year, or at different stages of their existence; nor does he seem to recognise the moult as a universal law of bird-life. To get so far as this, he would have needed to give his life to ornithology alone, instead of to all the sciences then known to man. Yet he does seem to know that some birds change their plumage at regular times. In the third book of his Natural History he writes: "Birds do not change their colour by age, except the Crane, which becomes darker. But from the change of season, as when it becomes cold, some of those which are of one colour only, black or gray or brown, become white, as the Raven, the Sparrow, and the Swallows; but of those which are white none have been noticed becoming black. And, according to the seasons, many birds change their colours, so that they fail to be recognised except by an expert." 1 In spite of the strange statements which this passage contains, the last sentence is as true as it can be. Once or twice he alludes to a seasonal change of colour as a well-known fact in some particular 
species. Of the Sparrow, for example, he remarks : "Some persons say that cock Sparrows only live for one year, and adduce as a proof of this the fact that early in the spring there are no birds with the parts beneath the chin black; but later on the black appears, and leads to the inference that none of the former generation have survived." 1

In other cases he was led into strange blunders, which well illustrate the difficulty of making observations in that day, and the danger of accepting as true what is believed by country people. He tells us that two birds, the Greek names for which we may fairly translate by Redbreast and Redstart, change the one into the other, the bird being Redstart in summer and Redbreast in winter,-a delusion probably arising from the fact that the Redbreast appears in Greece in the winter, after most of the Redstarts have gone away southwards. ${ }^{2}$ $\mathrm{He}$ also tells us of two other birds which change into each other in this way, the Black-head and the Figbird. ${ }^{3}$ We do not know for certain what species he is here alluding to; but Sundevall thinks he meant the Marsh Tit, which has a black head, and the Pied Flycatcher, which in autumn is not so very unlike the other. Again, he fancied that the Blackbird changed from black to russet in the autumn,

$$
1 \text { H. A. ix. 7. } 10 . \quad{ }^{2} H . A \text {. ix. 49. B. } 4 .
$$


I84 Summer Studies of Birds and Books cHap.

mistaking the dark rusty brown of young birds and females for a changed plumage in all Blackbirds. ${ }^{1}$ The Hoopoe, he seems to think, assumes in early spring the feathers of a white hawk; he is here following a very curious and difficult passage of Aeschylus, which he quotes in full. ${ }^{2}$ Yet in spite of these delusions Aristotle is careful to tell us that the Cuckoo does not change into a hawk in autumn, as so many people then believed, and believe to this day. ${ }^{3}$

I have said enough to show that Aristotle's knowledge of the general facts of the life of birds, though in some points strangely accurate, was on the whole very imperfect. His book was, in fact, a collection of odd bits of unsifted information, so far as it relates to living birds; his real interest lay rather in investigating the organs of animals by dissection. It is quite true, as Mr. G. H. Lewes remarked long ago, that there is a want of "out-ofdoorness" about his book; it does not smell of the fields and streams; its author was neither a sportsman nor a field-naturalist. And if we now turn to what he has to tell us of particular kinds of birds, we shall not find many traces of careful observation, though we may light upon some few details that are interesting to naturalists even now.

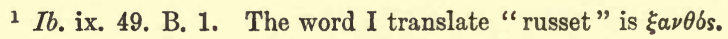

${ }^{2} \mathrm{Ib} .9 . \quad{ }^{3} \mathrm{Ib}$. vi. 7. 1. 
As I have said, Aristotle makes no real classification of birds: he does however divide them, for convenience sake, on more than one principle. In his Historia Animalium (viii. 3) he roughly divides them into-1, Flesh-eating birds, with crooked claws, which answer to our Raptores ; 2, Insect-eating

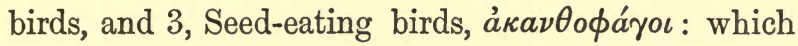
together answer to our perching and climbing birds, or more strictly to our Oscines, i.e. singing birds, with the Swallows, Swifts, and Woodpeckers superadded; 4, Vegetable-eating birds, including our Pigeons and their kin; 5, Wading or Swimming birds, which live chiefly on fish. ${ }^{1}$

I do not propose to discuss the first of these divisions, for it contains hawks and eagles with which we in England are unfamiliar. Let us go on to the very large second and third divisions, and pick out a few birds which may be interesting to us for particular reasons. What has Aristotle to say of the thrushes, that great tribe of which some members at least are to be found at the present day both in Greece and England?

There are three kinds of thrushes, says Aristotle : ${ }^{2}$ the largest is called $i \xi_{\circ}$ ßópos and is as big as a Magpie; the second ( $\tau \rho \iota \chi d \varsigma)$ has a strong voice and is

1 See Dr. Ogle's translation of the De Partibus Animalium, p. 244, for another system of grouping recognised by Aristotle.

2 H. A. ix. 20. 


\section{86 Summer Studies of Birds and Books chap.}

as big as a Blackbird; the third (ìıàs) is the smallest,

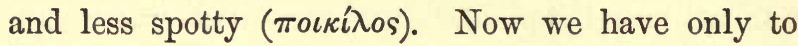
consult our lexicons to find out what No. 1 was:

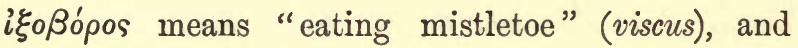
the bird was plainly our Missel-thrush. No. 2 may be also at once identified as the Song-thrush. No. 3 is, however, a puzzle. What thrush is there that is smaller than the Song-thrush, and can we be sure that Aristotle here really means a true thrush, and is not confounding some other bird with the thrush tribe? There is of course a small thrush, our winter friend the Redwing, which still appears in Greece in cold weather. But we must allow that Aristotle has not told us enough about his bird to give us any certain means of identifying it.

But now comes a very singular statement about thrushes. Speaking of them in general under the term $\kappa^{\prime} \chi \lambda \eta$, he says at the beginning of his fifth book that they make their nests, like Swallows, of mud, and place them in the high branches of trees, side by side and touching one another, so that for this reason they seem as it were a chain of nests. ${ }^{1}$ This is at first sight pure nonsense; but it is as well to remember that there actually is a thrush which builds very much in the way here described. Is it possible that Aristotle can have been informed of the peculiar gregarious habits of the Fieldfare in the nesting 
season, and have by some error attributed it to thrushes in general? The Fieldfare at the present day breeds in Sweden and Norway, and sparingly also in Germany, Poland, and Bohemia; but it is not unreasonable to suppose that two thousand years ago it may have bred further south in the forests of the Balkans and Thrace, where Aristotle may have heard of its habits during his residence in Macedonia with Alexander. ${ }^{1}$

Of the Blackbird, another of the thrush tribe, Aristotle has several curious things to tell us. I have already mentioned his error in thinking that all Blackbirds change their colour in winter. $\mathrm{He}$ also tells us that this bird nests twice in the year, and that the first eggs or brood are destroyed by the cold, for it is the earliest of all birds to breed. Few of us, I suppose, have failed to notice how often this is actually the case ; the too-eager bird, building in the evergreens in our garden, has to confess itself mistaken, and to abandon its eggs to the snow and the frost. $^{2}$ Then he tells us that there are two kinds of Blackbirds : the one is common and quite black, the other is more or less white, and is found in Cyllene in Arcadia, and nowhere else. ${ }^{3}$ What is the explanation of this white Blackbird? Surely that some one of Aristotle's correspondents had sent him word

1 See Sundevall, op. cit. p. 108.
2 H. A. v. 13. 1.
3 Ib. ix. 19. 1. 
from Arcadia of an albino specimen-a very common occurrence, as all ornithologists know; and that he had very naturally put it down as a different species, not having seen or heard of it elsewhere. Lastly, he is careful to distinguish from the Blackbird another of the family,-not indeed the Ring-ousel, which he does not seem to know, but the beautiful blue Rock-thrush of Greece and the East, which Canon Tristram tells us is probably the bird alluded to in the passage of the Psalms as "the Sparrow that sitteth alone on the house-top." 1

Our next bird shall be the Nightingale, the $a \eta \delta \delta \omega \nu$, the singer above all, the prima donna of Aristophanes' play. This is one of the birds about which incredible stories have at all times been liable to grow up; and Aristotle had not learnt carefully to distinguish truth from fiction, or had not been able to bring the fiction to the test of experience. He tells us that the hen bird sings as well as the cock until the eggs are laid; that the cock sings fifteen days and nights without stopping. ${ }^{2}$ Perhaps he did not mean his words to be taken quite literally; anyhow the bird probably sings more than almost any other while the leaves are coming out on the trees. But in other respects

1 H. A. ix. 19. Tristram, Natural History of the Bible, p. 202. In ix. 21 a rock-bird is mentioned and called wúvos, which may possibly have been the Wall-creeper: see above, p. 29.

${ }^{2}$ H. A. ix. 49. B. 2 
he writes of the bird with tolerable accuracy. It must have been well known to him, not only at Athens, but at his early home in Stageirus, for the woods of the Chalcidic peninsula are full of Nightingales. A traveller in Greece, not blest with a musical ear, once told me that at Mount Athos-not far from Stageirus-he was kept awake by frogs and Nightingales, and was unable to distinguish the two.

There is a passage in the fourth book of Aristotle's work in which it is said that the Nightingale has been seen teaching its young to sing. "Some kinds of small birds do not utter the same voice in singing as their parents do, if they have been brought up away from them and have heard other birds singing. The Nightingale has ere now been seen instructing its young, which suggests that the language is not by nature the same as the voice, but capable of being formed (by teaching)." 1 Here, as is quite plain from the next words, a distinction is drawn between the song and the voice or intonation, and the song of the bird is regarded as speech. We also note with interest that Aristotle knew what we moderns only learnt a century ago, that a bird does not sing its own song simply by instinct, but will sing another bird's song if the proper chance is given it. The proof of this which is offered is indeed one which many will

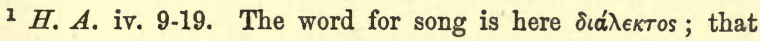
for voice $\phi \omega \nu \eta$. 
laugh at as impossible ; for the Nightingale, in England at least, always ceases its song long before the young are in a condition to learn it. Yet a lady, whose truthfulness I cannot call in question for a moment, has sent me a most explicit account of a singing-lesson given by a Nightingale to his children on the wooded slopes below the monastery of Camaldoli in Italy. It was in May, when in Italy the Nightingale might have brought up his first brood and be still singing; for I have myself heard this bird in song on the Italian lakes in July. The parent bird first sang his song in full, then went through it in detail while the young ones did their best to imitate it; finally, getting wearied, he flew to the other side of the valley and poured out the complete strain once more "in full-throated ease." I must leave this incident, faithfully reported to me, to the judgment of men of science.

Among the smaller birds noticed by Aristotle there are many, as we might readily imagine, which are very difficult to identify. And this is so not only on account of the brevity of his descriptions, but because the Greeks were so badly off for words to represent the colours they saw. About black and white, of course, there can be no mistake, but beyond these all seems in confusion. For red there are two

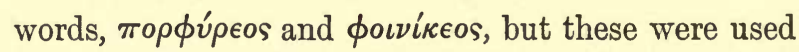
in Aristotle's time apparently for all shades of 
colours that have red in them, including yellow. There is a word that is generally understood to mean blue, кváveos; but it is hard to tell how many kinds of blue it represents. ${ }^{1}$ Aristotle is often content with telling us that a bird is of a bad colour, or a good colour, without troubling himself further, as if he knew well enough that his countrymen were not gifted with an acute colour-sense.

We may recognise, however, from his mention of its red or yellow crest, the smallest of European birds, the Gold-crested Wren, which he called by

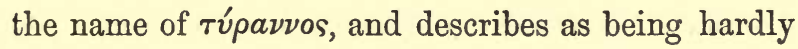
larger than a locust. Its golden crown had already given it the name of "Tyrant," and to this day it retains it in the form of Regulus or Kinglet. I have never been able to make out why this regal title should also have been conferred upon the Common Wren, which has no crown; yet not only is this little brown bird known over almost all Europe as King (Hedge-king in Germany, Roi in France), but the name is as old as the Greeks, for Aristotle says that besides its proper name "Trochilus," it was called "Basileus," and that the Eagle is consequently supposed to be jealous of it. ${ }^{2}$

1 Dr. Merry (Rector of Lincoln) tells me that it can include bright blue and all the shades of dark blue that pass into black, and quotes Eustathius $(1570,28)$, who interprets it as a colour like that of the cloudless sky.

${ }^{2} H$. A. ix. 11. 5. For the Goldcrest, viii. 3. 5. 


\section{Summer Studies of Birds and Books chap.}

Among other small birds we recognise the Titmice (aijit $a \lambda o \iota)$, of which he says there are three kinds: one as large as a finch, which is no doubt the Great Tit; one called the Hill Tit, with a long tail, which marks him as a familiar friend of ours; and one other, a small one, which may be our Marsh Tit, or, as some have thought, the Sombre Tit (Parus lugubris), a bird now common in Greece, but never found in our islands. ${ }^{1}$ Aristotle duly notes the large number of eggs laid by these birds, a fact which is more especially true of the Long-tailed Tit. ${ }^{2} \mathrm{He}$ also tells that they are enemies to the bees $;^{3}$ and it is a well-known fact that our Blue Tit will sometimes take a fancy to station itself close to a hive and work havoc on the bees as they fly in and out.

About the Wagtails, though they are obvious and striking birds, he is not very clear, and we cannot be at all certain under what name he refers to them. In one passage he mentions a number of birds which live by water and move their tails, but that does not carry us very far. ${ }^{4}$ Only in one case do we seem to recognise a Wagtail with any certainty, and that is in the description of a bird called Anthus-a name

1 H. A. viii. 3. 4.

2 Ib. ix. 16. He mentions seventeen and even more than twenty eggs as having been laid by one species, the "Blackheaded Tit,"-by an error perhaps for the Long-tail.

3 Ib. ix. 40. 37.

4 Ib. viii. 3. 13. 
which has been appropriated by ornithologists for the Pipits, birds closely related to the Wagtails. ${ }^{1}$ This Anthus lives in the grass, and by streams and marshes, and so far would do very well for a Pipit; but it is described as being of a fine colour, while all Pipits are brown or gray. I think then that we may follow Sundevall in guessing that it was one of the Yellow Wagtails of which I have said something in another chapter. It is curious, however, that Aristotle should describe this bird as being an enemy to the horse, for the familiar and amicable way in which the Yellow Wagtail will walk about the feet of horses and cattle is known to all of us. But he has many strange mythical statements about the antipathy of one animal for another which we cannot possibly explain; they are bits of old folklore of which the meaning is entirely lost.

Passing over some other small birds, such as the Acanthis or Acanthyllis, of which I have written elsewhere, ${ }^{2}$ let us see what he has to say of the Cuckoo. I have already mentioned that he discards the fable that the Cuckoo changes into a hawk in the autumn. The hawk which it resembles, he says, disappears about the time when the Cuckoo arrives, and reappears when the Cuckoo departs. If this hawk be the Sparrow-hawk, as we might guess

1 Ib. ix. 1. 22. Sundevall, p. 116.

2 A Year with the Birds, ed. 3, p. 245. 


\section{I94 Summer Studies of Birds and Books cHap.}

from its likeness to the Cuckoo, it is true enough that it is a migrant to the south in eastern Europe during the autumn. The hawk, he says also, has hooked claws, which the Cuckoo has not; nor is the head like that of the hawk, but both feet and head are rather more like those of a pigeon. And he further notes another point which is fairly true, that the colour of the Cuckoo is rather of a spotty than a stripy character. ${ }^{1}$ Of course he is acquainted with the Cuckoo's peculiarity in laying her eggs, and the following is the answer to the question as to what becomes of the eggs or young of the unlucky bird in whose nest she has chosen to lay hers:- "Some say that when the young Cuckoo grows it ejects the other young birds, which then perish; others say that the foster-mother kills them and feeds the young Cuckoo with them, for the beauty of the young Cuckoo makes her despise her own offspring. People say that they have been eye-witnesses of these things. Others say that the old Cuckoo comes and devours the young; others that the young Cuckoo is so big that it eats up all the food which was meant for the rest"; and lastly he comes back to the first explanation he gave, which is indeed the right one, that the young Cuckoo in some way gets

${ }^{1} H$. A. vi. 7. 2. Such must be the meaning of the words

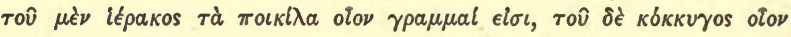
$\sigma \tau \iota \gamma \mu a l$. 
rid of the others. In other points about the Cuckoo, such as its timidity and the date of its disappearance, he is quite correct; and the whole account can leave no doubt in our minds that he had more accurate knowledge about the bird than about most smaller and less curious ones. ${ }^{1}$

The Cuckoo's mate, or Wryneck, is so exactly described by Aristotle that I cannot forbear quoting the whole passage. "Some few birds have two claws in front and two behind, as the bird which is called $\iota^{\prime} \gamma \xi$. It is a little larger than a finch, is of a variegated colour, and has another peculiarity beside that of its claws: for its tongue is like that of the snakes. It can protrude this tongue to a length equal to the breadth of four fingers, and draw it back again into its former position. Further, it twists its neck right round without moving the rest of its body, just like the snakes." ${ }^{2}$ This passage proves that a really remarkable bird could fix the attention of an observer of that day, though the less curious species might fail to do so. The Woodpeckers are also described with accuracy; Aristotle is aware that they too have long tongues, with which they catch ants and other insects, but he

1 H. A. ix. 29.

$2 H$. A. ii. 12, foll. The Greek name used by Aristotle is, as in so many cases (e.g. Sitta, Certhia, Apus, Cinclus, etc.), still retained as one of the scientific names of the bird (Iÿnx torquilla). 


\section{Summer Studies of Birds and Books cHAP.}

does not seem to have dissected a Woodpecker, or he would surely have had something to tell us of the wonderful machinery of that tongue. ${ }^{1} \mathrm{He}$ speaks of three kinds, the largest of which,-as large as a fowl,-is certainly the Great Black Woodpecker, "which hunts for worms so diligently that it is said even to destroy a tree by hollowing it out." The Nuthatch seems to be reckoned among the Woodpeckers; for what other bird can it be that has been known to fix an almond in a crevice of timber to get a good purchase for his bill in cracking it, and to succeed at the third blow ${ }^{2}$ Lastly, we shall not fail to recognise our familiar little Tree-creeper in the Certhius whose name it still bears; for it is described as being of a bold disposition, as searching for its food on trees, and as being especially diligent in this practice. ${ }^{3}$

He has perhaps more to tell us of the Kingfisher than any other bird, assuming, that is, that the bird which he calls ả $\lambda \kappa v ́ \omega \nu$ is really our Kingfisher, a point on which I myself have no doubt at all. Let me quote his description, that every one may judge for himself. "It is not much larger than a sparrow;

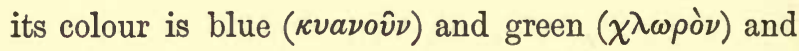

1 $H$. A. ix. 9. It is odd that he does not notice that these birds, like the Wryneck, have two toes before and behind. The Three-toed Woodpecker is not found in Greece ( $P$. tridactylus).

2 Ib. sec. 4.

3 H. A. ix. 17. 2. 


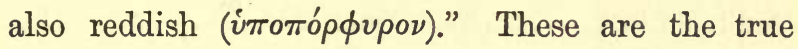
colours of the bird, the under parts of which are of a bright chestnut. But he goes on to say that there is no part of its body without all these three colours, which is not true; for the red and the blue-green are very distinctly marked off from each other. But this, though incorrect, seems to me to be no more than a proof that Aristotle had never had the bird in his hand, and this is exactly what we should expect; it was very seldom seen, he says, and when it did present itself to the eye, how were the Greeks to catch it? Without guns this would be a most difficult matter. I conclude therefore without hesitation that Aristotle is here describing the effect produced on the eye by the Kingfisher as it darts by you, when you may get a glimpse of all its hues without the chance of marking them off from each other. Had he seen a dead specimen, I am confident that he would have noted (as Pliny did) the white patch behind its neck, as well as the distribution of its tints. As it was, the only other feature that he was able to mark was the long thin bill, which he has described correctly. ${ }^{1}$

I could mention many other birds of which

1 $H$. A. ix. 14. In other passages (v. 8 ; viii. 3) I will not undertake to say that Aristotle is alluding to the Kingfisher, or the other species (Ceryle rudis) which is also found in Greece. My friend Canon Tristram, in a paper in the Ibis for April 1893, maintains that in these passages he is speaking of a 


\section{98 Summer Studies of Birds and Books chap.}

Aristotle has given us accounts which are interesting either on account of their accuracy or their blunders, or the remnants of folklore contained in them; but my object is not so much to examine these accounts in detail, as to give some general idea of our indebtedness to Aristotle as the father of all serious inquiry into the nature and habits of birds. I will conclude by quoting one example of the value of records of animal life made two thousand.years ago. When we compare such habits with the records of animals at the present day, it is possible that here and there we may find some slight difference; and if our records of to-day be carefully preserved for another two thousand years, it may be that other differences may be found to have established them-

Tern, and that the word as used by the Greeks generally must be so understood. I readily allow that a word which had become so mixed up in a mythological tangle as this one may have been used of more birds than one; and I agree that the bird on the Greek coins mentioned by the Canon is almost beyond doubt a Tern. The one point I would maintain is, that in the description quoted above Aristotle was thinking of our Kingfisher, Alcedo ispida; and Canon Tristram himself seems to acknowledge this, though he will not allow that the word kvdveos can mean blue (see above p. 191, note 1 ).

I endeavoured to explain the myth of the Halcyon days in a note to the third edition of $A$ Year with the Birds, p. 259. My explanation, however, does not go very far; and I take this opportunity of saying that those who are interested in the unravelling of such tangles may look forward to a much bolder and more far-reaching solution of the difficulty in the forthcoming Glossary of Greek Birds by Professor Darcy Thompson. 
selves. Conservative as animals are, and especially birds, they do undoubtedly possess the power of modifying their habits to suit themselves to altered conditions of life ; and every faithful record of those habits at one particular point of time may at some remote date become a landmark in the slow progress of a species.

As I write this paper there are but a few yards from me, under the eaves of the house, several nests of that familiar bird the House-martin, which we have come to associate so closely with the dwellings of man. How long, we may ask, has it had this habit of building on human habitations? There are still places, even in England, where it nests under the ledges of cliffs ; and we may be certain that this was its original habit. Can we learn anything from Aristotle as to the time at which it first began to take advantage of the architectural skill of man?

I cannot find any passage in his book that betrays a knowledge of this bird. He certainly knew the Swallow, and describes very accurately its manner of building with mud and straw; he also knew the Swift, and possibly too the Sand-martin or the Cragswallow, or both; but he has not a word to say of a bird of this kind which has a conspicuous white patch just above the tail. If the House-martin had been known to him at all, I cannot believe that he would have confused it with others of its kind; and if 
it had then built its nest on houses, I am certain that he would have recorded the fact. The bird forces itself on the attention of the veriest beginner in ornithology; and if it had then built on houses in Athens, or Stageirus, or Mitylene, such a man as Aristotle could not have failed to notice it there. And we can hardly conclude that it was not to be found in Greece in his day, for it is common enough there now, building on houses as it does elsewhere. ${ }^{1}$ There is but one explanation that occurs to me-namely, that the House-martin had not then become a Housemartin, but was still a bird of the cliffs and mountains, and had not attracted attention sufficiently to get itself distinguished from others which resemble it. And the reason of this is not far to seek; for the houses of that day were not of a kind to induce the bird to make use of them. The ordinary Greek house was no solid structure of stone; and the very passage in which Aristotle compares the Swallow's building materials with those which man himself uses is sufficient to show us this. ${ }^{2}$ And of nobler

1 Seebohm, Brit. Birds, vol. ii. p. 181. Mr. Seebohm describes it as also still nesting on cliffs in some places in Greece.

${ }^{2} H$. A. ix. 7. Curiously enough, he seems to have fancied that in this case the bird learnt from man the art of making mud for building. (For the material of the ordinary Greek house, see article "Domus" in the last edition of Smith's Dict. of Antiquities, by Prof. Middleton.) There are several points of great interest in this passage of Aristotle, among which I may 
buildings-great temples, for example-there were as yet but few.

Four centuries later the Roman Pliny wrote his voluminous Natural History, and in treating of birds copied freely from Aristotle. But I find that after describing the Swallow he adds a morsel of information of his own. "There is another bird of this kind," he says, "which builds its nest now and then (raro) in houses"; and he goes on to describe a nest, which seems to be the House-martin's. ${ }^{1}$ Pliny then knew the bird, and knew that it occasionally nested in houses; and we are justified in inferring that it began to change its habit somewhere between the time of Aristotle and Pliny, and probably not long before the Christian era. Note that this was the very time at which that change in architecture was going on in Greece and Italy, which we have seen on a small scale at Meiringen. In the place of the small and rude houses of mud or wood,

mention that he had got almost as far as Gilbert White in his knowledge of the way in which the excreta of the young birds are disposed of. Cp. Nat. Hist. of Selborne, Letter 55.

$1 H . N$. x. 42. Pliny has somewhat exaggerated the form of the nest - "totos supinos (i.e. nidos), faucibus porrectis in angustum, utero capaci." This description would, indeed, agree even better with that of the nest of the Rufous Swallow ( $H$. rufula; see Ibis, vol. ii. p. 386), which makes a long funnel-shaped entrance to its nest. But I cannot find that this bird ever builds on human habitations. If this were so, we might identify it with Pliny's bird, and my argument about the House-martin would so far be invalidated. 
in which Greeks and Romans lived in their earlier stages, great temples, porticoes, villas, palaces, basilicas had sprung up, and even the ordinary dwelling-house, as we know from Juvenal, was lofty, if not always substantial. And as man improved his dwellings by aid of his reason, so did the birds follow his footsteps.

And now I must really close this lecture, in which I have merely done my best to give you a few examples of the way in which the old philosopher treats his subject; of the curious carefulness of his observation in many instances, as well as of the errors into which the first great naturalist was of necessity liable to fall. Let us be willing to forgive him these, and rather render him due honour for his lifelong endeavour to get at truth. Nothing is to me more astonishing in the whole history of thought and knowledge than that the man who wrote the Ethics and Politics should have been capable of putting together a work like the one I have been telling you of. It argues a richness of mind, a variety of interest, a universality of thirst for knowledge, with which we have very little acquaintance in this century. 


\section{CHAPTER VIII}

\section{GILBERT WHYTE OF SELBORNE}

GILBERT WhITE died a hundred years ago, 26th June 1793; the Natural History and Antiquities of Selborne was first published four years earlier. Since then many a book of the same type has appeared and disappeared, but White still keeps his hold upon the English mind. Though many may talk of his book without having read it through, and still more may have read it through without discerning its quality, the fact remains that the demand for it is steadily on the increase, and that it is finding its way into the village library and the home of the working man. The name of Gilbert White is a household word with every one who loves his own incomparable country, with its thousands of villages as homely and as sheltered as Selborne.

It is strange at first sight that this should be so at a time when we seem passing from a period of poetry and romance into one of stern reality, 


\section{Summer Studies of Birds and Books chap.}

when the rural population is being drained into the towns, when the squire and the parson are going down in the world, when leisure such as White enjoyed is a rarity and almost a crime, and when the study of economic problems should be driving out of our heads the delights of wild nature or of sport. But the Englishman has always been a strange and self-contradictory creature. With all his commercial instincts and his town-bred vulgarity, his phases of stern Puritanism and political excitement, he has never yet lost that love of the country which is rooted in the life of the manor and the village. Even with the American the same passion still lives; he took it with him to New England in the seventeenth century, and the books of Mr. John Burroughs and Miss Mary Wilkins have lately made us aware how strongly it survives in him in the nineteenth.

Surely the spread of the factory system, and the consequent growth of huge towns, has rather strengthened than weakened this love of all things rural. We pine for pure air, for the sight of growing grass, for the footpath across the meadow, for the stile that invites you to rest before you drop into the deep lane under the hazels. But in the last century there was no need to pine, when there was hardly a town from which a man could not escape into the fields when he would, without 
toiling through grimy suburbs where the problems of economic science force themselves at every turn on his mind. In those days men loved the country simply as their home, not because they were shut away from it; they took it as a matter of course, and seldom wrote about it. Now we mingle a touch of self-consciousness in our passion for it, which finds its expression in a multitude of books.

What a literature of the fields has sprung up since the Natural History of Selborne was first published! Not to mention the poets, from our novelists we seem almost to demand the familiar descriptive background, careless too often whether it be a mere daub, or the work of a master such as Mr. Blackmore or Mr. Hardy. And then again, there is an ever-increasing call for books whose whole intention is to open our wayward eyes to country sights and sounds. Since the days of White we have had Knapp, Howitt, Jesse, Knox, Wood, and others who are still readable and still read; and later, and in a higher region of literature, we have had Kingsley, Jefferies, and Mr. Hamerton. To-day a score of books of the same type are published every year; and good and bad alike seem to find abundant readers. The Selborne Society has spread all over the land; in most of our public schools there is a Natural History Society, which has taken root in the very citadel of athleticism, and effectually 
holds its own, issuing its report yearly. Neither athletics nor examinations can kill the old instinct of Englishmen; it is as strong as ever, and the scientific spirit of the age has given it a useful turn.

All this literature of the country, all this youthful endeavour, may be traced back not only to the natural instincts of the English country gentleman, like so many other institutions of ours, but to the work of the first country gentleman who could shake himself free from the tyranny of books, and describe what he saw around him in simple and engaging English. White's book has taken possession of the English mind as securely as the Complete Angler, or even as Robinson Crusoe. At the distance of a century one may well ask why this is so, and what has given the book its enduring quality. This I will try to do; but first I must say a word of the man himself, for I think it is in one characteristic of his, and one that in these days some might call a weakness, that the secret of his fame is to be found.

$\mathrm{He}$ was born in 1720 at the village which will always be associated with his name, and in which he spent almost the whole of his long life. The connection of his family with Selborne was, however, an accidental one. His grandfather, after whom he was named Gilbert, was a Fellow of Magdalen 
College, Oxford, and was presented by the College to the living of Selborne in 1681. This Gilbert White was apparently a well-to-do man, for he left considerable bequests to the village, and doubtless inherited wealth from his father, who had been an eminent citizen of Oxford in the time of Cromwell. Sampson White, whom we may call the founder of the family, was a draper in the High Street; he had migrated to the city from Coggs near Witney, where his family had been settled for many generations. He was Mayor in 1660, served as "butler of the beer-cellar" at the coronation of Charles II., and was knighted among many others at that gay time. Thus I may claim the recluse of Selborne as in some sort an Oxfordshire man. But that his own Hampshire folk may have their due, I must add that not only was his grandmother a Hampshire lady, but, if Anthony Wood is to be trusted, the family was "originally descended from the Whites of South Warnborough in Hampshire." 1

Apparently the love of village life was strong in the family; for John, son of Gilbert the Vicar, settled down in Selborne after his father's death as

1 I am indebted for these particulars to my friend the Rev. Andrew Clark, who has allowed me to consult the third volume (as yet unpublished) of his edition of Wood's Life and Times. Since this paper was written many details have come to light about White's life and ancestry. 
a country gentleman of some property, married, and had several sons by Miss Holt of Streatham. He could afford to give his sons a good education, for he sent Gilbert to a tutor at Basingstoke who was himself a scholar, and who knew how to bring up his sons as scholars. Both these boys were younger than Gilbert; the elder one, Joseph Warton, matriculated in the same year with him at Oriel, and became afterwards Head Master of Winchester; while the younger, Thomas, the friend of Johnson, was afterwards Fellow of Trinity and Professor of Poetry. Of these schooldays we know only one incident, told us by White himself in his letters on the antiquities of Selborne. "When a schoolboy, more than fifty years ago, he (the author) was an eyewitness, perhaps a party concerned, in the undermining of that fine old ruin at the north end of Basingstoke town, well known by the name of Holy Ghost Chapel." Any one who will read the rest of the passage will see that even in his old age White could dwell with some complacency on this exploit. With a quiet humour only possible in an age that knew no "Society for the Preservation of Ancient Buildings," he quotes Dryden :

"It look'd so like a sin, it pleased the more."

But the history of White's early years is lost almost as completely as the memory of his features, 
of which no portrait seems to be in existence. Doubtless he was an animal-loving and bird-nesting boy, and acquired an observant habit without knowing it; but I doubt if he began any systematic study of natural history till he settled down at Selborne. He often refers to his earlier sporting days, and it is likely enough that it was only when sport began to fail him that he set about that minute attention to animal life that has chiefly made him famous as a naturalist. But under Mr. Warton his sporting instincts must have been kept under due control. He became a scholar, as scholarship was then: he read the Latin poets, and learned to love and quote them; and when he went to Oriel in his nineteenth year he was sufficiently equipped with learning to be eventually elected Fellow.

His Fellowship began early in 1744, and he held it until his death almost fifty years later. As a Fellow he was of course ordained, and later on he took a small college living in Northamptonshire; but he took it on the understanding that he should never reside there, and to this resolution, which in these days seems shocking, he steadily adhered all his life. I do not wish to dwell on this, or on his other relations to his college, which were not wholly of a pleasant character; but Oxford men are aware that a non-resident who insists on his right to take 
his turn as Proctor, or who holds his Fellowship for fifty years, is not likely to be popular with his college. Yet in Dr. Bell's edition of the Natural History of Selborne we have such irresistible evidence of White's kindness of heart and charm of manner as can hardly be reconciled with Mr. Shadwell's severe verdict in his account of the history of Oriel. ${ }^{1}$

The fact seems to be that the age was a selfindulgent one, and that Oxford was not the place to correct the tendency in a man whose mind was beginning to be ruled by one overmastering motive. Life and leisure in his native village were what White longed for, and it is to his indulgence of this longing that we owe his immortal book. This weakness, if such it be, is the clue to his character, and to the excellence of his work as well as to its shortcomings. Happy, amiable, observant at Selborne, he was perhaps too much discomposed at leaving it to be altogether himself elsewhere. For such close and keen observation as his, it is really necessary to be master of one's own time, to be absolutely free from hurry and interruption, and this not only that a bird or insect may be carefully watched, but that what is seen may sink quietly and surely into the

${ }^{1}$ See The Colleges of Oxford, edited by Rev. A. Clark, p. 121. It is only fair to White to add that for the greater part of his life at Selborne he held curacies, either there or at a neighbouring village. 
mind. Few men have enjoyed such leisure, and few indeed have been so well qualified to use it fruitfully. In our own day Darwin is a familiar instance; and it is interesting to find in him too; in his later years, the same discomposure at leaving home, the same unconquerable love of his own home life. I have sometimes felt almost exasperated that White has nothing to tell us of his occupations at Oxfordnothing of the animal life that cannot have been less abundant round the city in his day than it is now. But he was White of Selborne, not White of Oxford. If natural history has lost anything by his want of adventure, it has after all gained more; for the unique value of his book is mainly due to the persistence with which he followed his own instinct, and to the complete ease and isolation in which his acute mind worked at home.

To this ease and isolation,- the complete absence of hurry and worry,-we may attribute indeed not only the scientific value of his observations, but the perfection of the form in which he was able to record them. How leisurely his life was we may see if we consider the fact that he did not publish his book until he was close upon seventy, and that the letters which compose it were spread over a long period of years. During the last forty years of his life he did not often leave home, and when he did leave it, never went far or for long. There was a definite work for 
him to do at Selborne; and though he could have hardly realised the importance of the lesson he was giving to English naturalists, he could justify this gratification of his natural instincts on excellent grounds. Let me quote his own words. "Though there is endless room for observation in the field of nature, which is boundless, yet investigation, where a man endeavours to be sure of his facts, can make but slow progress; and all that one could collect in many years would go into a very small compass." Or again: "Men that undertake only one district are much more likely to advance natural knowledge than those that grasp at more than they can possibly be acquainted with; every kingdom, every province, should have its own monographer."

The full force of sentences like these can hardly be felt by one who merely reads White's book in the light of our modern knowledge. They are indeed invaluable warnings for all time, and every man who puts pen to paper to write on natural history might do well to learn them by heart. But we must remember that in his day the accurate study of the life and habits of animals was almost unknown, and that facts which are now the common property of naturalists were then awaiting discovery or verification. If, for example, we take his favourite study of ornithology, it is at first astonishing to find that for a whole century before his book was published no 
Englishman had made any important contribution to the science. So far as England was concerned, White had to take it up almost exactly where Willughby and Ray had left it. And if we open Willughby's book, published by his friend Ray in 1678 , and turn to his account of any of the insignificant-looking little birds that swarm in our woods and fields, we shall find that the study of their songs, habits, and movements had then hardly begun, and that the scientific mind was still to a great extent under the tyranny of books and traditions. Willughby's is a great name, and had he not died young, he might have settled down in England to a leisurely study of the living birds; but he seems to have been in temperament the very opposite of White, and his short life was mainly spent in foreign travel. The work was still waiting for the man who would not travel, whose curiosity was indeed unbounded, but fortunately kept under control by the overpowering love of home. "It is now more than forty years," White wrote in 1779, "that I have paid some attention to the ornithology of this district, without being able to exhaust the subject; new occurrences still arise as long as any inquiries are kept alive."

It would be quite superfluous to give illustrations of the closeness and acuteness of White's observation of birds. We need but open the book at random,- 


\section{I 4 Summer Studies of Birds and Books chap.}

or if we would study some one letter as a model both of matter and manner, we may turn to one of those famous and familiar ones which treat of the habits of the Swallow tribe, and, bearing in mind how little was really known of these birds in his day, take in paragraph after paragraph with just such care and close attention as he himself bestowed on his favourites. White must never be read in a hurry; we must take his book in the spirit in which it was written. There is a favourite phrase of his which exactly expresses that spirit. We should read it, as it was written, with a nice observation and discernment. Though I said that it is superfluous to quote, I cannot refrain from the pleasure of copying a single short paragraph by way of illustrating this "niceness " of his; I alight on it at random, and it strikes me as giving us a little picture of the man himself at his work, satiating his unlimited curiosity, and bringing the large range of his knowledge to bear on the examination of some special point.

"At some certain times in the summer I had remarked that swifts were hawking very low for hours together over pools and streams; and could not help inquiring into the object of their pursuit that induced them to descend so much below their usual range. After some trouble, I found that they were taking Phryganea, Ephenerce, and Libellulce (cadew-flies, may-flies, and dragon-flies), that were just emerged out of their aurelia state. I then no longer wondered that they should be so willing to stoop 
for a prey that afforded them such plentiful and succulent nourishment."

This passage may aptly remind us that White was by no means only an ornithologist. It is true that many of the most exact and enduring of his observations were made on birds, for birds were always about him, and it is clear that he loved them best. There is not a writer on birds but has drawn on him,-with or without acknowledgment,-for the history of the Stone-curlew, the Ring-ousel, the House-martin, the Sand-martin, the Goat-sucker, and many more; and where he did not get far himself he threw out hints "in order to set the inquisitive and discerning to work." But to him not only a bird, but every living and growing thing, was a delight and a mystery. The words I have just quoted occur in a very brief letter to Barrington on earthworms, which is an excellent example of the true nature and value of his work as a whole. "A good monography of worms," he says, "would afford much entertainment and information at the same time, and would open a new and large field in natural history." This letter was written in 1777 ; just sixty years later Darwin read his first paper on this subject to the Linnæan Society; and we had to wait nearly another halfcentury before the monograph at last appeared. I do not know whether Darwin's long series of observations was originally suggested by this remark of 
White's, but I am strongly tempted to fancy that it must have been so. Darwin at least remembered White's letter, and quotes it as showing his accuracy on a point of detail often misapprehended. White's keen eye, and his habit of thinking leisurely about what he saw, did in fact enable him to seize on the great secret of worm-economy which Darwin probed with such marvellous and patient persistence. "Earthworms, though in appearance a small and despicable link in the economy of nature, yet if lost, would make a lamentable chasm. Worms probably provide new soil for hills and slopes where the rain washes the earth away; and they affect slopes probably to avoid being flooded." But the whole letter occupies little more than a page. It was not in White's nature to investigate such a subject thoroughly, though it was one which might have been pursued without the aid of modern science. He was a pioneer, and would never for a moment have thought of himself as a great naturalist. But it would be hard to say how many of the discoveries of the nineteenth century may not have sprung from seed which he so freely scattered. To mention one more instance, he was the first naturalist, so far as I know, to notice that "protective mimicry" in the habits of animals the study of which has become so popular and so fruitful at the present day. Just as but lately I observed how some tiny partridges, 
which I had disturbed, ran and thrust their heads into the first patch of brown grass they could find, so White more than a century ago noticed that the young of the Stone-curlew skulk among the stones of some flinty field, "which are their best security, for their feathers are so exactly of the colour of our gray-spotted flints, that the most exact observer, unless he catches the eye of the young bird, may be eluded."

One unconsciously strays back to birds in talking of White; but his notes range over the whole field of the animal and vegetable life of his district. We all remember the tortoise at Ringmer, which after many years' acquaintance became his guest and friend at Selborne; the field-crickets at the "Short Lithe" behind the village, which eluded his efforts to domesticate them in his garden; the little harvestmouse which he was the first to describe, and whose "procreant cradle" was rolled across his tableperhaps the very table that now stands in the Common room of Oriel College-without discomposing the eight naked and blind little inmates. Trees, too, were the objects of his particular affection, though he for the most part left botany to the specialist. Insects he evidently studied with great care; and here again he makes a suggestion which has only of late been seriously taken up, influenced by a conviction, of -which several proofs may be 
found in his book, that the study of nature may and should be made to be of direct practical value to mankind. "A full history of noxious insects hurtful in the field, suggesting all the known and likely means of destroying them, would be a most useful and important work. A knowledge of the properties, economy, propagation, and in short of the life and conversation of these animals, is a necessary step to lead us to some method of preventing their depredations."

Though his records are confined to his own district, White's conception of the work of the naturalist was as broad and rational as that of Aristotle. He took mankind into his view, and nothing escaped him that was worth recording of the economy, the superstitions, the language, of the people who lived around him. One of his best letters is devoted entirely to the subject of rush candles and their manufacture; and we have in another some acute reflections on the disappearance of leprosy in England. And it is most important to remember, if we would judge his book as he would himself have wished it to be judged, that by natural history he understood not only the study of animals and plants, but the study of all natural productions and occurrences, - of every natural phenomenon, that is, which was brought to his notice in his neighbourhood. In the advertisement to the first 
edition he makes it clear that he considered himself to have made an attempt to give the public an idea of what parochial history should be, and to have tried to lend a helping hand towards "the enlargement of the boundaries of historical and topographical knowledge." In the Antiquities of Selborne, issued originally together with the Natural History, he showed that he had a remarkably just sense of what was worth recording, and how it should be recorded. The documents that he accurately transcribed relating to the Priory of Selborne are of real historical value, more especially the account of the visitation by William of Wykeham in 1387. Even now the example he set might serve as a model for village antiquaries; for the professed antiquary is often a pedant, and limits his interests and inquiries to the most prominent buildings and their history. White's mind was fresh and bright in old age as in youth, his tastes were human and catholic; and the history of the works of man in Selborne was for him only a part of what the parish had to contribute to the whole sum of human knowledge.

A word must needs be said about the literary quality of White's book. It is interesting here again to find that the ease and isolation of his life had a marked influence on the form into which he threw his thoughts and observations. In the latter part of his life, as we have seen, he rarely left the 
beloved village; but in spite of his local isolation, he kept himself well acquainted with what was doing in the world of science, both by the purchase of books and by frequent correspondence with friends. $\mathrm{He}$ had no neighbours of his own tastes, and it became all the more necessary for him to make the most of friends at a distance. Now it was part of the singular good fortune of his whole life that he had no less than four brothers, all with tastes suited to his own; two at least of these were good naturalists, and another became the most noted publisher of his day in the department of natural history. John settled at Gibraltar, and is often mentioned by Gilbert as sending him valuable information; Thomas became a Fellow of the Royal Society, and a writer of some note; Benjamin was the publisher of his brother Gilbert's book. Brothers are not usually good correspondents, but the spell of the Hampshire home never failed in holding this wonderful family together. Long before he began his more elaborate correspondence with men of greater renown, Gilbert must have fallen into the way of compressing his accounts of home and Selborne within the limits of the old-fashioned letter-sheet; and as letters were then in vogue in literature, it was only natural that when he was at last persuaded to publish, he should keep to the form in which he had all through life been accustomed to express his thoughts. And we 
cannot be too thankful that here, as always, he followed his natural instincts.

The letters to Pennant and Barringtọn, doubtless revised carefully for publication, must have been originally written with greater care and attention than he would bestow on his brothers, for both correspondents were men of mark in the literary and scientific world. Pennant was the most voluminous writer of his time; Barrington was a strange compound of lawyer, antiquary, and naturalist. To them no doubt White was at first an interesting and useful curiosity, and in his eyes they were great figures, men who had published books and knew the great world beyond Selborne. But whether his correspondents were great men or small, White could not but write to them in his own happy way. There is not a pompous or affected sentence in all these letters, which number exactly a hundred. The influence of the age on his language is of course visible enough, but he is always simple and natural, never lofty or pedantic. Compared with many later writers on the same subjects, he is a classic. He calls a spade a spade, and never affects fine writing; with him a bird flies, instead of "winging its way," as some ornithological authors will have it.

Oddly enough, the only overweighted sentence I can discover was probably the last one he wrote for the book. Prefaces often give their writers much 
trouble, and in the last sentence of his preface White's pen seems for once to have stuck fast. It shows us very plainly that he was here out of his natural element; but it may well have pleased the " circle of gentlemen whose intelligent communications, as they have afforded him much pleasing information, so, could he flatter hinself with a continuation of them, would they ever be deemed a matter of singular satisfaction and improvement." After all, this preface is brief enough, and itself marks his steady adherence to the maxim of Linnæus which he quotes elsewhere with approval, "Verbositas hujus sæculi calamitas artis."

The enduring popularity of the letters is however due not only to their brevity, variety, and accuracy, but in great part to the little felicities and quaintnesses of expression in which they abound. Every bird-lover remembers the "sibilous shivering noise" of the Wood-wren, and the "full, sweet, deep, loud, and wild pipe" of the Blackcap. Sometimes we get an unusual word used with rare effect, as when the tame raven, kenning the toad as he put forth his head, gave him such a severe stroke with his beak as put out one eye. Sometimes it is an ordinary word that is used in a sense which to us at least is fresh and telling. "The life and conversation" of the birds occurs more than once, and more than once too we hear of "delicate" weather. Occasionally we 
come across an old word in a new sense, with perhaps a touch of humour lurking in it, as when we are told that the tortoise has an "arbitrary" stomach, and can refrain from eating during a great part of the year. That White had a strong sense of humour is beyond a doubt, for it comes out clearly enough in the more chatty private letters which have been published in recent years $;^{1}$ but in those to his distinguished correspondents he indulges it rarely and very quietly. Once, in one of the later letters to Barrington, he could not resist the temptation, and thus describes the aspect of the hens when a hawk, captive and disarmed, was placed in their yard: "Imagination cannot paint the scene that ensued; the expressions that fear, rage, and revenge inspired, were new, or such as had been unnoticed before; the exasperated matrons upbraided, they execrated, they insulted, they triumphed."

But Gilbert White's book needs no introduction or comment. Every one, young or old, can see for himself that, in the language he uses of his own chalk hills, there is something "peculiarly sweet and amusing" in its shapely letters. Of himself we know little; he would never sit for his portrait, and from such tradition as has come down to us, we can

1 More especially in the letter to Miss Mulso from Timothy the Selborne tortoise, ending "Your affectionate reptile," which will be found in the second volume of Dr. Bell's edition. 
only imagine a little upright man with a keen eye and complacent expression, and probably with a strong common sense and practical turn of mind, quite ready to assert himself where he thought he had a right, but also quite unwilling to push himself into notice in a world where he was not at home. Still, if we are really to know anything worth knowing about him, we must go to his book, and read it again and again; and it will always charm us with the same lesson of keen and sympathetic insight into nature, of perfect candour in reasoning, and of admirable taste in expression. Sentimentality and pedantry are alike absent from it; where he feels tenderly he rather hints it than expresses it, and when his scholarship induces him to quote a line of Virgil, he invariably hits the mark with it. As a man he must have had his faults, but as the writer of his one book he assuredly came very near to perfection. 


\section{CHAPTER IX}

\section{BINDON HILL}

I OFTEN doubt whether there can be such another hill as Bindon in these islands; I at least have never found it. In foreign lands there are famous hills, and health-giving hills-Alesia, Epipolai, or the Acropolis; but I feel sure that they cannot offer such store of delights, for mind and body too, as Bindon does. Tropical hills may be gorgeous and overpowering, but they are often, to say the least of it, uncomfortable. Under the shadow of Bindon I am just now reading Darwin's Voyage Round the $\dot{W}$ orld, and have been crossing the Andes with him, and trying to penetrate by perilous paths into the mountainous recesses of Tahiti. I have been led to fancy that if the Beagle could but have sailed into the little cove that lies under Bindon's flank, as into a newly-discovered harbour, and have landed the great naturalist to take a walk and explore the overhanging down, he would have carried away such recollections of insects, plants, birds, views, geological 


\section{Summer Studies of Birds and Books cHap.}

strata, and fresh air, as would have made his usually sedate page eloquent of pleasure never to be forgotten.

Those who now sail, or rather steam, into this deep and tranquil cove are in the summer season to be numbered by thousands. They come from all the watering-places near at hand, they come and eat and stroll and depart, and, fortunately for me, they rarely discover Bindon. For Bindon rears his crest some five hundred and fifty feet above the sea at his base, and is not very easy of access from the steamers' landing-place. I do not think that I myself truly discovered him the first time I came here, even under the tuition of a valued friend who had known him from boyhood; I trod his whole length more than once, but my diary shows me that I did not understand him. For ten successive years I have never once missed him altogether; and now when his wellknown form comes in sight from the window of the train, I feel youth still stirring in me with strong desire to mount upon his grassy back.

I cannot paint Bindon, and indeed I think he does not readily suggest beauties to the artist's eye. I have twice walked his whole length in company with a young artist, who saw nothing on either occasion to delay him. Turner has drawn the steep cliffs with which his western end strikes down into the cove, but they are not the chief objects in the 
drawing, nor do they give you any idea of what Bindon really is. The magnificent precipice of his eastern end, pure white chalk falling sheer into a clear blue sea, was the subject of a picture in a watercolour exhibition not long ago. But, except at his two extremities, Bindon is not attractive to artists; and to understand him truly it is not enough to contemplate him from without. You must spend whole mornings with him, lying on him, and being of him. Better to be bookless there, in my opinion, even on the warmest day; I cannot keep my attention on the page, there is so much life and fragrance around me. There is so much that is beautiful to look at, not for the artist, but for me; whether I turn southward to the sparkling sea with its white sails, or look northward over long miles of a purple heathery plain, or lie down and look into the long dry grass which the sun is turning golden, and catch the millions of gossamer webs, stretched by some invisible fairy spider from blade to blade over the sward.

But we will contemplate Bindon for a moment, and stoop to consider him outwardly as a hill, before we stretch ourselves upon his back and see what he has to show us. He is nothing more than a mighty mound of chalk, nearly two miles long, and rising to his highest point about midway; yet he is unlike any other chalk hill I know of along the whole southern coast. He has an individuality quite his 
own, and all the creatures seem to know and love it. Even among the hills of his own narrow range-a range full twenty miles in length-Bindon is quite unique in the charm he exercises over all bees, butterflies, and grasshoppers.

This curious individuality of his is easily understood if he be looked at in front, either from the sea or inland from the north, so that his whole length is seen at once, together with the long ridge of which he really forms a part, stretching far to east and west. In all this range Bindon is the only isolated hill; he does not slide easily down to any saddle which connects him too familiarly with another rise; he stands alone, and the sea washes his base at either end. As you approach him from the east along the ridge, you become aware that you must descend into a gap to the sea-level, and then toil upwards for nearly a mile before you reach his highest point. And when you stand at last on the top, you find that you have yet nearly another mile before you drop down at his western end to the shore of the little cove I spoke of. Thus Bindon demands his tribute of those who would worship on his high places; but he is a hospitable and kindly hill, generous to all who know him. At the very first step you take in mounting him from Arishmill Gap he offers you, even in the most arid season, a draught of clear cold water, bubbling up ready filtered from beneath his deep chalky recesses; 
he has prepared for you a smooth track of soft elastic sward, which carries you up till all your real labour is over; and then, when you are getting hot and tired, he has ready for you without fail a cool breeze-a breeze like a happy conversation with a friend you prize, in which you can lie down in solitude and yet not be alone. This is so on most days from May till October; on every day, that is, which you would naturally choose for a walk along these noble hills.

Bindon's individuality, then, is chiefly to be explained by his isolation, and I am much inclined to think that the animal life in which he abounds is in a measure isolated too. And this is made all the more likely, as I fancy, by the fact that Bindon has a lowland territory which is all his own, quite distinct from his turfy uplands. Within his mighty embrace, on the side towards the sea, there lies at his feet a space of land a mile long, and in its broadest part a third of a mile wide, which is completely shut in by the sea beyond it, by the precipitous cliffs of Bindon's two extremities, and by his own steep slopes rising from the whole length of it to the northward. It is cultivated, but carelessly ; for it is naturally exposed to the salt breezes, and the farmer to whom it belongs can only reach it by a rough chalky track which crosses Bindon at an angle like a pipeclayed shoulder-belt. His great waggons cannot be taken over this, but you 


\section{Summer Studies of Birds and Books chap.}

may meet a rude cart laden with some thin-looking produce jolting slowly down the ruts towards the farm, and looking as though at any moment it might send its burden rolling down the grassy steep. This curious tract of half-wild land is thus in reality a part of Bindon ; but its vegetation is totally different from his. Here, and on the rocks and broken sandy slopes which overlook the sea, grow many curious plants, as well as abundance of thistles and other ordinary weeds; and here, I think, the butterflies, which so abound in the summer on Bindon's back and flanks, must pass the earlier stages of their existence as caterpillars and chrysalides, until their wings enable them to seek for change of scene and fresh blossoms on the heights above.

The geological relation of Bindon to this lower territory of his is an interesting one; and, though no geologist, I may venture a word on what addresses itself so readily to an eye at all accustomed to observe. Bindon is a single segment in a long spine of chalk down stretching from Weymouth Bay to Poole Harbour. The whole of this spine was at one time protected from the sea by a rampart of Portland rock, with which it was connected by a series of beds of sand and clay. In its eastern half it is still so protected; from Swanage Bay to Arishmill Gap the voracious sea has never been able to set his mark upon it. But the little stream that 
at this latter point makes its way to the sea-the only one that pierces the range during its entire length - has here eaten away the chalky strata in the course of ages; and here too the fronting rampart has given way to the sea, leaving only a few jagged rocks, well loved of cormorants, to show where it once stood. In came the remorseless tide, washing away the intervening clay and sand, till it reached Bindon's eastern flank, where sea and weather between them at last exposed those magnificent white cliffs which Mr. Fripp chose as the subject of his painting. At his western end too the sea has found an entrance, and, breaking through the rampart here again, has wrought out a beautiful circular basin by the regular wash of its tides; here again, too, making raids on Bindon's western end, where even now the traces are plain of dangerous falls of chalk, one of which (so the coastguardsman tells me) raised last winter a roar like that of an avalanche. But in front of the whole length of Bindon, from the cove to the eastern cliffs, the protecting rampart still stands firm; the sea has found no chance to eat away the clayey and sandy strata which lie between this bulwark and the chalk; and it is here that they still form that tract of half-wild land which Bindon may claim as his own territory, enclosed as it is between his two precipitous ends, his steep southern front and the sea.

If this description has been at all comprehensible, 


\section{Summer Studies of Birds and Books chap.}

it will perhaps occur to the reader that Bindon must offer a splendid position to an enemy landing on the coast, or to a tribe driven from the interior and clinging to the last available defence. The low-lying land that he shuts in would supply both food and water : sheep could pasture on his summit; and the exceeding steepness of his sides would make it impossible, without artillery, to carry the hill in the face of a sufficient number of defenders. And that Bindon has at one time been put to some such use as this there is very clear evidence to be found. At the top of the steepest part of the entire length of his landward front there runs a well-marked double line of fortification; not indeed such huge trenches and ramparts as once made an impregnable fortress of Maiden Castle near Dorchester, or even such as guarded Ring Hill, Bindon's nearest neighbour to the eastward, but a line which was once, no doubt, quite sufficient for its purpose, touching the precipitous cliffs at each extremity of the hill, and strengthened at the western end, where the slope is rather less steep than elsewhere, by an inner line of defence much stronger than the outer one.

What people made these fortifications, in what age, and with what object? I have hunted in massive books of antiquities for answers to these questions, but their splendid quarto pages speak, as usual, with a most uncertain sound. How, indeed, should any one have 
an answer, or one that is not wildest guesswork? Did some invading chieftain steer his black ships into the cove, and possess himself of Bindon, as a first step to the conquest of the inland country? Or was this the arx, the $\pi \tau o \lambda i^{\prime} \theta \rho o \nu$, of the people of the district round about, to which they could fly for refuge at the approach of an enemy from the north? There is a sense of melancholy in these blind attempts to pierce the utterly forgotten past; all the human endeavour, endurance, and courage that may have spent itself on Bindon has vanished for ever out of sight, leaving only these dumb earthworks to tempt the local antiquary into fanciful conjecture.

But these are mere accidents of Bindon; slight human scratchings on his massive form. Let us climb up on his back, and see what he himself really is,- -how he clothes himself, and what creatures delight to live on him and about him.

The monster's shaggy hide is, perhaps, the first of his real attributes that seizes on the eye. Each steep flank is clothed with this hide; it is now, in autumn following a dry summer, brown and withered, but not mangy-looking like that which some of his neighbours wear. In the summer it is a soft golden-green, which the sun looks into lovingly and lights up, for the ends and edges of the longer blades are always brown, which passes into a golden glow as the sun comes from behind a cloud. On the steep slopes it hangs 
downwards just like a living creature's fell; and I believe it has been this, more than anything else about him, which has always made me think of Bindon as a huge reposing animal. This grass has one quality which is most delightful to those who have learnt to know Bindon well. It is at all times so thirsty that it absorbs moisture with most astonishing rapidity; on the southern and more sunny side the rain or sea-mist is at once drawn into the chalky soil, but on the northern, where the grass is thicker and longer, if you probe with your fingers you may feel a touch of dampness in a mossy undergrowth. But there is no need to be alarmed at this; the hide protects you from it like a waterproof, and you may cast yourself down on it half an hour after a shower, if the sun be shining, without a thought of rheumatism.

On Bindon's narrow spine,-and it is another peculiarity of his, which I have not mentioned, that he narrows towards his highest point, till the ridge itself is not more than a dozen paces across,- - on this narrow spine of his, and on many a level spot elsewhere, there grows a short and velvety turf, as deliciously elastic to the tread as the air that breathes over it is exhilarating to the mind. Touch it with a stick, and it will in some places give gently to the pressure; and if you cut out a bit with a penknife, you find a depth of an inch or more of a 
soft, black, peaty substance. It is here that on a summer evening you may see the green lamp of the glow-worm, even at this height of five hundred feet; striped shells of all colours are strewn about here, chiefly the endless varieties of one abundant species. Spiders and beetles are to be sought for rather in the fringe of longer grass which bounds these turfy spaces; but the chirruping grasshopper is everywhere. At every step this September they leap out by twos and threes; and I think it must be these which are just now attracting such numbers of Kestrels to Bindon's southern slopes, where the life in the grass is most abundant. They are hovering all around, not high in the air, as one sees them inland, or waiting long on motionless wing till you are tired of watching them, but poising themselves for a minute not many yards above the grass, and then quietly settling down on it to eat their prey. So intent are they on this pursuit, that you may occasionally creep quite close to them, though not quite close enough to see what it is they are after. No one seems to molest these beautiful birds; the folk here, by calling them "Beetle-hawks," show plainly that they associate them with no mischief to the innumerable rabbits which burrow on the hillside; and indeed, if they did now and then carry off a young one, more good would perhaps be done than harm. So they are left to enjoy on Bindon a 
paradise of peace and plenty, very different from the lot of our hard-driven Kestrels of the too-wellpreserved midlands.

In the summer the air of Bindon is sweet with thyme; but it is in September that I have most often been here, when the wealth of bloom is over. There are, indeed, still plenty of flowers, all of them blue, purple, or yellow, and nearly all small in size. The plants are here all dwarfed, like those of the high Alps; they nestle down in the soft herbage, not caring to put out long stalks which might be rudely handled by strong winds. Among these is one which in September is Bindon's special ornament, peering up with an upright corolla of deep purple wherever the grass is short; some plants are bolder than the others, and shoot up for three or four inches, branching into a little cluster, while often you see but one purple bell, the base of which is quite hidden in the turf. This is a campanula which grows to some height in the hedgerows below; but it is apt in richer soil to become a somewhat coarse and untidy plant, and never equals in beauty the little gentian-like bell-flower of the hills.

Hovering over these plants, and over harebell, hawkweed, scabious, and dwarf thistle, are innumerable humble-bees and butterflies. Even at the very top, and on a breezy day, a Red Admiral will pass you, fresh from the chrysalis, with that matchless 
flight of his; he works those splendid wings for a moment, then Radit iter liquidum, celeres neque conmovet alas. The Painted Lady is almost as beautiful, and this year she is to be seen everywhere here; the more sober-coloured Grayling is always abundant on Bindon. This latter fly, and also some others, seem here to be peculiarly liable to a minute parasite, which raises one and sometimes two or three swellings of a brilliant vermilion on their bodies, apt to stain the finger if it be broken. The Clouded Yellow is to be found here in most years, and is now in extraordinary numbers; I have seen also a single specimen of the beautiful pale variety, in a boy's collection made here during the last few weeks. The Marbled White affects one end of Bindon, and the exquisite Clifden Blue the other; the latter haunting the warm sunny hollows on the southern side, where its delicate wings do not get caught too roughly by the wind. The Chalk Hill Blue and the Common Blue are to be seen on most chalk downs, and they are in great abundance here; but the bright sheen of the wings of the Clifden Blue is a thing to be remembered, and it is not too often seen.

At the base of Bindon is one of the few homes of a Skipper peculiar to this stretch of coast,-a sober-coloured little fly, which still survives the raids made upon it by collectors. And as the Skippers bring us by an easy transition to the 


\section{Summer Studies of Birds and Books cHap.}

moths, I will mention a strange spectacle I once came upon, and have never chanced to see again. Almost at the very top of the hill, in the little hollow of the fortifying lines, there were thistles growing to about a foot in height, and all of them in bloom; on each flower there were from two to six handsome Burnet-moths, and at the base of each plant lay the dead bodies of others! I must have walked two hundred yards at least before I left the thistles and their crowded occupants behind me.

But after all it is the bird-life on Bindon which gives me the greatest pleasure. Beside the Kestrels, whose way of living is altogether gentle and harmless, the fiercer Sparrowhawk is to be seen here; a far more dangerous bird, both for the young rabbit and for the conspicuous Wheatear, whose bright white patch on the upper tail-coverts marks him out as an easy prey. I was once just reaching the crest of the down two or three miles to the westward, and had my eye on a Wheatear who was flicking his tail and bowing after his manner on a stone hard by, when a Sparrowhawk suddenly shot over the ridge in front of me, swooped upon the bird, missed his aim, tumbled right over on the ground, and then seeing me went off, doubtless in a bad temper. Now and then a still more formidable bird of prey will sail over Bindon. Only the other day he passed over me as I lay on the grass ; sweep- 
ing upwards to the white cliffs, he sent the little birds flying in all directions, then turned,-whether with a victim in his claws I could not see,-and in a moment, as it seemed, was full a mile away. This is the Peregrine Falcon, who still holds his own, and has somewhere every year a nest among these abrupt cliffs. And but half an hour ago a Raven passed along the entire length of Bindon in little more than a minute, - a rare sight, though once in April I have seen and heard a pair circling round the inaccessible cliff not far away to westward, where that year they must have built their nest.

The Gulls, of course, are Bindon's especial pride; but just now they are nearly all from home, gone inland perhaps to feed on the newly-ploughed fields. Only when the "schools" of mackerel have come into the bay, darkening and making crisp the water here and there beneath the cliffs where Gulls and Cormorants breed together in spring, have we seen a Herring-gull arrive mysteriously and suddenly, hover over the disturbed water for a moment while catching the whitebait which the mackerel are chasing, and then settle down quietly on the wave to swallow and digest. No other sea-bird seemed to follow these shoals; but the fishermen were waiting for them with a huge net, and twice we were there to see a great draught of fishes-more than a thousand mackerel twinkling with prismatic hues 


\section{Summer Studies of Birds and Books chap.}

in the sunlight, tiny whitebait suffering the same fate as their enemies, with here and there a plaice, a sole, a prickly John Dory, a whiting, or a heavy, leathery-mouthed "sea-carp."

Of the other birds of Bindon I have hardly space to tell; of the cheerful Titlarks which abound on the summit, and sometimes descend to the shore to join their cousins the Rock-pipits, and to enjoy a change of diet; of the House-martins, which are here Rock-martins, building their nests under the ledges of Bindon's eastern cliffs ; of the Stock-doves, whose splendid deep-blue plumage one can often admire here from above-a thing impossible in the flat country. I must pass by the Stonechats that abound on the hedges below, and the Ring-ousels that every autumn rest here awhile on migration, betraying themselves by their loud metallic alarmnote, and, if they happen to face you, as indeed they rarely do, by the conspicuous white crescent on their breasts. Even my favourites, the Wagtails, must be no more than mentioned; all the three common species have shown themselves to me on Bindon's slopes, or by the spring at his foot, during the last few days, all probably travelling quietly eastward.

But of the great stream of migration that can be watched in mid-September from the top of Bindon I must needs say just a word. If the wind be blowing gently from east or north, so that the travellers do 
not have it directly behind them, take a station anywhere on the narrow ridge, and look for the passage of Swallows and Martins from west to east. They will come in parties great or small, and if the day is warm and the breeze on their beam, they will dally a while on Bindon's flanks, and may deceive you into fancying that they are his own birds. But watch steadily, and you will see that they are gradually passing you; follow them with the glass to the eastward, and you may make sure that they are hastening to some point where the Channel is narrower, and where perhaps they will wait a day or two for a favourable crossing, "with great yearning for the further shore." Rarely do they travel with a strong wind behind them; it carries them too fast to allow them to collect food, and disturbs the sit of their feathers. Once I have seen a few in this predicament, and travelling so straight and so swiftly that I tried to time them with the secondshand of my watch. To the best of my belief they covered half a mile in fifteen seconds, or little more; they were therefore making nearly two miles in a minute, and supposing they went straight on at the same pace, might reach the coast of Kent in little more than an hour.

But they will not go so far to-night; the sun is sinking, and, clear as all the country is to the northward, there is a mist rising from the sea which will 


\section{Summer Studies of Birds and Books снир.}

presently wrap Bindon in its soft and moist embrace. Should we be caught in it we might chance to see a spectre, as I did the other night when strolling here in deepening twilight; a human figure approached me coming up the farmer's white track, and when I went to meet (as I thought) my friend, it suddenly and utterly vanished, and not a living thing was to be seen upon the bare hill-side. What other mysteries has Bindon yet in store for me?

Let us take one last look before we descend; first at the gray and misty sea, then by St. Aldhelm's Head and Ballard down by Swanage to Poole Harbour and the little ancient town of Wareham, at the eastern end of that great heath of which the Dorsetshire novelist has told more than one sad tale; and so northward along the distant line of those "crowns o' Do'set downs" of which the Dorsetshire poet has sung in his tender mood and quaint language, till the eye reaches in the west the monument to Nelson's Hardy, and Weymouth Bay and Portland, where on the Bill the two warning lights will soon begin to twinkle. And lastly, as the russet and lavender tints of autumn twilight begin to spread over the hills nearer at hand, it is pleasant to let the eye drop upon that little village nestling in the deep curve of the valley below usour home at night as Bindon is our home by day, from whose dark red chimneys "azure pillars of 
the hearth" arise to mingle with the growing twilight :

" Et jam summa procul villarum culmina fumant, Majoresque cadunt altis de montibus umbræ."

Even now it is hard to leave Bindon; but he is composing himself to sleep, with all the life that is about him-unless indeed those fairy spiders spin their gossamer in the stillness of the night, to adorn him in the morning's sunlight with a network of intangible lace. 


\section{CHAPTER X}

BILLY : A MEMOIR OF AN OLD FRIEND

September 24th, 1893.-Once more I am strolling in that great meadow where just four months ago I saw the last of Billy. All along the crumbling banks of the stream the water-voles are flopping into the water just as they did on that afternoon; such sound of life to me is always pleasant, but I am now alone, and there is no little white roughcoated animal to share with me the gentle excitement. For eleven long years Billy and these watervoles knew each other well; on his side there was a constant anticipation of triumph, on theirs as persistent an assurance of escape. Once only in all those years did he realise the hope so often stirred afresh in his sanguine breast. One warm summer afternoon a large, fat, velvety vole had stretched himself for a nap on the grassy bank in the sun; Billy, a few yards in front of me, saw that at last his chance had come, and before I could interfere the soft creature had awakened only to be put asleep for 
chap. x Billy: a Memoir of an Old Friend 245

ever. It was the work of an instant; the life seemed to pass as swiftly as the Kingfisher that darts by me and is gone round a bend of the stream. I took the vole up in my hands while Billy trotted on in search of another; the eyes were bright as jewels, the fur was clean and wholesome to the touch, without a trace of injury. It was no cruel end,-death following on sweet sleep, with a bare flash of consciousness between them.

I raise my eyes from the stream, and the next object that meets them again reminds me of my old companion. If he were here, that little herd of young bullocks would be edging towards us, with a stupidly malicious curiosity written on their faces. Billy was wholly indifferent to them; he knew them to be degraded, witless creatures, and would even let them come up and smell him before he deigned to put them to sudden and disgraceful flight. He knew that the secret was to turn upon them suddenly, and he emphasised this rapid change of policy with a howl so startling and diabolical that no four-footed creature, save one of his own kind, could ever withstand it for a moment. That he might some day be tossed or trampled on never once entered into his calculations; and as he grew older and stiffer, if we had let ourselves be penned in the corner of a field, I used to take him in my arms and make a sudden charge upon the enemy. At the moment 


\section{Summer Studies of Birds and Books chap.}

when we came within a yard or two of the most inquisitive bullock, Billy invariably uttered his terrific war-cry, and in an instant the foe was scattered.

Turning from the brook to cross the great meadow, I am swiftly carried back to the day when we had an exciting chase just here after a fine stoat. Billy surprised this little Bohemian in the very middle of the field, a hundred yards away from any covert; and with me to head him back from hedge and ditch, it looked for a while as though his hour had come. In vain he twisted and doubled; the pursuer pressed hard upon him. But then a strange thing happened; suddenly, at the most critical moment, he vanished utterly out of our sight. It was just as if he had donned an invisible coat, or had been danced away by the fairies of the greensward. We searched the ground carefully, Billy with his nose and I with my eyes; and we found that the little thief had known a trick we never thought of-he had vanished into his mother earth by way of a mole-run.

Not every stoat escaped Billy's vigilance; but once he was baffled by another manœuvre almost as astonishing as that of the mole-run. One hard winter day I was watching some birds, while Billy was trying to climb a tree after a squirrel, when I saw a rabbit emerge from a little wooded hollow hard by, and advance with a curious weariness into the open field. A yard or two behind the rabbit ran 
a twisting red snake-like creature, which I presently made out to be a stoat and his long waving tail. When about thirty yards away from me, the rabbit dropped down and seemed to resign himself quietly to his fate, and in an instant the stoat had leaped upon his neck. I whistled up Billy, who abandoned the squirrel and came with alb. speed to the front. At his approach the stoat left his victim and fled; then the tables were turned, and a furious chase followed, up and down, round and round, the quarry edging nearer and nearer to cover, till he suddenly vanished up a young tree some twelve or fifteen feet in height. The dog was fairly puzzled; the thing was done so adroitly, and with such amazing speed, that I myself can hardly say that I saw the stoat go up that tree. If I saw anything, it was a sudden glint of red colour that came and went on the treestem. Nor could I see him in the tree; but a stone quickly brought him down, and after another brief chase he made his escape into the hollow. I turned to look for the rabbit; he had picked himself up, and was making for a covert at the other end of the field. Then I searched the spot where he had lain down to die, and found one tuft of fur on the grass. Billy had saved him from the very jaws of death.

I have been telling of strange disappearances, but the strangest of all was that of my old dog himself. Across the meadow, bounding it on the other side 
from the brook, is a deep and wide ditch, which all this spring and summer has been almost dry; and at one point this ditch is hedged on both sides for some distance by tall overgrown thorn-trees. On Sunday afternoon, 21st May, I was standing close to this hedge, looking at a Yellowhammer's nest, when I saw Billy for the last time. He was getting old and rheumatic, and even on a fine afternoon he often preferred to stay at home and guard the premises, lying on a favourite spot in the garden whence he could see and be seen from the village street, and relieving his feelings with a short bark when any one passed by. But this afternoon when I started for a walk he jumped up at once and followed me.

I was soon hot and tired on the glaring road, and turning into the meadow I strolled along the stream, while Billy pursued his customary line of duty by keeping an eye on the water-voles. When I found the nest, he was at my heels, scenting about in the tussocky grass; and since then I have never seen him, alive or dead. For a few minutes I did not miss him; then all my whistling failed to bring the little white figure into view from behind some distant hedge. But he knew so well how to take care of himself that I went homewards without misgiving; and it was only after an hour or two, when still no Billy burst into the room with his familiar salutations, that I roused myself to make inquiries. He was 
not on the premises, nor had he gone to afternoon tea at the one cottage where he had friends and descendants. Some one suggested that he might have been caught in a snare set for hares or rabbits, and I hurried off to search the place where I had last seen him.

Not a trace was to be seen of him in the open field, and I called and whistled to the empty air. If he had fallen into the stream in pursuit of voles I must easily have found him, for it was so low as to reveal every object in its bed. Not till I penetrated into the ditch through a gap in the tall hedge did I come upon any possible clue to his fate. There, half buried in the drying mud, was the ghastly carcase of a fox ; it was stark and stiff, and must have been there some time; the head was stretched out, and the sharp teeth were protruding. And close to this horrid object was the mouth of a large drainpipe, at least a foot in diameter. I could see at once by the look of the ground that this drain ran a long way up into the field; what more likely than that it should be a favourite retreat of foxes? The one in the ditch might have been caught in the pipe by a sudden flood of February rain, and swept out to decay where I found him lying.

Now Billy, as became a wire-haired fox-terrier who feared no living thing, was always much given to investigating the haunts of foxes, which are abundant 
in our neighbourhood. In my company he had had rare opportunities of watching the blue-eyed cubs at play, restrained from attacking them by the absolute control which I gradually acquired over him out of doors. Before that control was complete he once dived into a fox-hole, remained for twenty minutes in the bowels of the earth, and then only emerged, all yellow with sand, to vanish instantly into another hole. Even in his old age he one day turned up an old gray fox in a bit of gorse where I was looking for Stonechats, and trundled after him on stiff legs with his own peculiar air of indignant contempt. And the sad conclusion forced itself upon me, as I stood looking at the dead fox and the drain-pipe, that for once the old dog had miscalculated, or not calculated at all, that he had been attracted by the carcase in the ditch, had scented foxes up the drain, made his way up it, and met with a speedy and sportsmanlike end. Sic, sic juvat ire sub umbras!

Further inquiry confirmed this guess. It was confidently asserted by a man who worked hard by that a vixen had taken up her abode in the drain. Some indeed thought that, once in the pipe, the dog had failed to make his way back again, but this I refused, and still refuse, to believe. At great labour and cost we might have opened the drain for some distance, but this was not to be done on the Sunday on which he vanished; and as no sound could be 
heard up the pipe, and repeated search failed to reveal any fresh clue, I next morning gave up all hope of seeing him again. Requiescat in pace,-in his drain-pipe, a sepulchre not unmeet for an aged hunter. Let me think of him as spirited away from me in that great meadow, his happy hunting-ground while he lived,- caught away while no eye was upon him, like Romulus of old in the Campus Martius. And as all his life his ways were his own, I like to think that he languished on no sick-bed like a common dog, but chose to depart suddenly from my side before old age had quite disabled him.

I have never found my fondness for animals turning into sentimentality, and I am not now going to drop a tear on that drain. By one emotional friend of his Billy's decease was said to have "cast a gloom over the whole village"; but I am much disposed to think that those who really grieved were very few, and that his many enemies rejoiced. And it must be allowed that there was nothing in this dog to excite sentiment in any human breast. He despised all uncalled-for display of affection; what was proper to be done when his master returned home he would do with the most genuine zeal, and would then suddenly resume his ordinary staid demeanour. He could not bear to be nursed; he never begged, or jumped on your knee. When in an unusually happy frame of mind, he would occasionally 
rub his head against my legs, but beyond this he did not trust himself to go. He never was a trouble in the house, like the fidgety little smooth-haired terriers; he had a just perception, not only of his own dignity, but of his master's need of quiet. If a gentleman may be defined as one who never takes a liberty, Billy was a gentleman.

Nor was his outward appearance of a kind to inspire emotion. His wiry white hair was extraordinarily long on his neck and shoulders, like a lion's mane, and was a most effective armour against the attacks of his enemies; but it fell away on his flanks as he grew older, and became at last so short as to give him the appearance of having been shaved. I frequently pointed out this defect to him, and the tacit answer was always the same, that his nature required it and so it must be. So with his ears; while one drooped gracefully, the other stood stark upright, and had tempted his most deadly foe to bite a mouthful out of it ; and this incongruity, together with some slight difference of colour, gave to one side of his face the aspect of a damaged warrior, and to the other that of a mild infant. Tail he had none to speak of, and he was also "underhung." No one could readily have guessed that he came of a good stock; yet within that quaint little carcase there was a mind worth making acquaintance with.

Not that he was what is called a clever dog; I 
should rather have said that his apprehension was slow. I taught him one "trick," and then we came mutually to the conclusion that tricks were beneath his dignity. But if not clever, he certainly had an odd kind of intelligence all his own. His native obstinacy, which was intense, and well expressed in his ears and coat, combined with a rigid training to develop in him an extraordinary tenacity of habit. When once he got an idea in his head, it was not only fixed there for ever, but carried out to its logical results in ways which frequently puzzled me. So stubborn was his nature, that our relations were a series of compromises; my sway over him was so far limited that it was an absolutism grounded on the immutable laws of his own nature. Thrown together as we were for so many years, and often alone for days together, we came to recognise and act upon each other's strong and weak points. In nonessentials I never forced his obstinacy, but where he had to be bent to my necessities I did not spare the rod, and he felt the degradation so keenly that it was rarely needed twice. So it was that he learnt to obey certain signals in our walks, which prevented him from disturbing any birds which I happened to wish to observe.

The strange power of the association of ideas was never presented to me either in man or beast so forcibly as in Billy. When I first took him to 


\section{Summer Studies of Birds and Books cHap.}

Oxford he lived in a little yard opposite the college gate, where we made him snug with plenty of straw and fixed him up with a light chain. This chain must have made a deep impression on his mind; all his attempts to avoid it came to nothing, and at last it associated itself so firmly in his mind with rest and food, that when we ceased to use it he never noticed the change. Though perfectly free, he woke up every morning firmly believing that he was still chained. When I went to call him for a stroll after breakfast, though burning with desire to come, he would lie in his straw and look at me ruefully. "What's the use of calling, when you see I can't come?" he plainly seemed to say ; and every morning I had to make believe to unfasten him before he would rush barking into the street. His delight at this imaginary release never once failed him, and he signalised it by startling some listless errand-boy with a sudden outbreak of his war-cry, or by tearing to pieces the nerves of some old lady who might be passing at the moment.

One day I succeeded in turning this delusion of his to good account. I took him into the Parks, and seeing that a cricket match was going on, I turned in that direction; but was presently confronted with a notice that no dogs were allowed on the ground. A handy row of hurdles suggested to me that I might tie Billy up to them, but I had no string-only my 
pocket-handkerchief. But the handkerchief on my part, and the delusion on his, were quite sufficient for my purpose. I brought him to the hurdles, passed the handkerchief through his collar, and pretended to fasten it, while I really whipped it into my pocket again. Then I spent an hour looking at the cricket, and when I returned, my little white dog was still where I had left him, with his head leaning up against the hurdles.

The strictly logical character of his reasoning led him into another habit of which I could not at first understand the meaning. I had always been accustomed, if he failed to appear when I was starting for a walk, to ask him on my return where he had been, and whether he had been up to any mischief; and the tone in which these questions were put appealed very strongly to his moral sense. But I was a little discomfited to find that he had extended the idea of delinquency to every absence of mine, no matter how long it had lasted. When I returned home and came in sight of the house, I always saw him looking out for me (he knew of course when I was expected), but no whistling or calling could ever entice him to run and welcome me. He lay there sadly and silently, in the full consciousness that he ought to have been with me all the time, and evidently doubtful of his reception. Only when I had put it beyond doubt that I was not displeased with him would he 


\section{Summer Studies of Birds and Books cнар.}

suddenly recover his spirits, and rush in frantic delight all round the garden and through the house.

Billy came to me one October in the country when he was a month old, a very quaint-looking puppy; he passed his infancy and childhood there, but when he had grown up, and showed some signs of getting into bad habits and company, I decided that he must take a course of "the higher education," and brought him with me in the following October term to matriculate at Oxford. From this time he kept his terms regularly for no less than nine years, and only retired from the University when he became stiff and rheumatic with advancing age. At first he lived entirely in the aforesaid yard, but he gradually acquired the status of a privileged dog, spent his afternoons in my room, and often finished his day in the society of the Fellows before the Common-room fire. He may even be said to have taken his Master's degree, for he showed such a decided partiality for an old M.A. gown of mine, that it became wholly appropriated to his use; and nothing could ever induce him to repose quietly on my arm-chair, or even in his own basket, unless this gown were spread for him beforehand. All these privileges he valued very highly, and if any strange dog, no matter how big, ventured to intrude himself within the sacred precincts of the college, a word from me was sufficient to send Billy flying at him with such a 
sudden access of fury as never failed to quench his curiosity for ever.

Before he had been long at the University I began to notice in him an increased seriousness of demeanour, and a certain discrimination in his choice of friends, such as are not always characteristic of the human undergraduate. For heads of colleges he showed a profound respect, and would single them out for special attention during a walk round the Park. To this rule, however, the Head of his own college was, I regret to say, an exception, for he too possessed a dog who was naturally a thorn in Billy's side. Among professors and lecturers I am inclined to think that he preferred the philosophers. His selection of undergraduate friends, on the other hand, was not based on any recognition of their intellectual attainments; the "pale student" he regarded with indifference, if not with aversion, and he extended his good-will more readily to the honest fellow of a sporting turn, or to the scholar who did his duty without overdoing it. When such pupils came into my room, he would generally get up and welcome them; of the others he would take no notice, or growled if they made advances to him. Once only he showed for a while some tendency to prefer the undergraduate to the don, and insisted on spending much of his time with a Devonshire lad living over my head, who seemed to have some strange attrac- 


\section{Summer Studies of Birds and Books cHap.}

tion for him. For the college porter he had a lively affection, grateful for much care and kindness; but neither undergraduate nor porter ever wholly weaned him from his dignified repose on the old M.A. gown. $\mathrm{He}$ was thoroughly loyal to his own college, and showed his loyalty, as many of his friends will remember, by refusing to accept food from a member of any other. Indeed I half suspect that the name of that college took shape in his mind as a verb imperative or permissive, meaning simply to eat.

Of literary society he saw something, without betraying any mauvaise honte. One valued friend indeed, whose sympathies are too entirely human, failed to appreciate his worth, and was repaid with comparative neglect; but he has made up for it since by some choice and touching Latin elegiacs dedicated to the memory of the vanished one; sublatum ex oculis quorimus invidi. Among English poets Billy could reckon two as his casual acquaintances; and he was equally at home with a commentator on Aristotle's Ethics or with an editor of Cicero's Letters. Even with the editor of Macmillan's Magazine, who honoured him with special attention, he showed no visible uneasiness ; and more than once accompanied him to those classic hills whence "the eye travels down to Oxford towers," to lie on the heather till disturbed by gamekeepers, or to battle with the snow on "the white brow of the Cumnor range." 
Billy's vacations were spent in the country, and he was my companion in all my rambles after birds. But it is perhaps with Oxford that I shall most closely associate his memory; for in all the three admirable photographs of him which I possess he appears in his capacity as a college dog. Two of them are college groups, where he is conspicuous among sixty or seventy figures; in the third and best he is associated with five grave dons, of whom three are now professors in different parts of the world, and the fourth is the head-master of a famous school. Even here his appearance is in perfect keeping with his surroundings. He has an air of gravity, if not of learning; he seems to share the sense of responsibility which shows itself in the composed and thoughtful features of his distinguished friends. Yet there is just that touch of pathos about his expression which reminds one that it is after all only a dog and a dependant,-a pathos that combines a little oddly with his sturdy frame and stubborn hair. But it is as an oddity that he will be remembered by all who were admitted to his friendship; an honest, blunt, warm-hearted oddity, quaint alike in his many virtues, and in those frequent shortcomings without which he would have been no true dog. 


\section{CHAPTER XI}

\section{DEPARTING BIRDS: AN EPILOGUE}

THE last days of summer slip away only too quickly, and the birds slip away with them, often quite unobserved. It is much easier to record the arrival of birds accurately than their departure. They themselves are more active, and many of them are more showy, when they come in spring; they perform their journey more rapidly, and are obviously eager to reach their old summer homes. We too are apt to be more alert at that time; the few dead weeks of February and early March are followed by a season when all who live in the country with their eyes open are daily in that state of good spirits which realised expectations bring with them. But when the last comer among the birds has brought up his young, when the songs have ceased and the moulting has begun, it may be that we fall in with the humour of the birds and become less active and less keenly observant. However that may be,-and I have no right to speak but for myself,-it is at least true that 
any given observer will have less to tell you of the dates of departure than of the dates of the arrival of birds in his district.

There are several reasons for this besides the want of continuous patient observation. During the moult the birds are apt to disappear from view, and when it is over, unless they begin to sing again-which they will not do in unfavourable weather-we may easily miss them or fancy that they have altogether deserted us. Then comes another difficulty. Our own local birds may really have left us, and yet we may be deceived into thinking that they are still here by the appearance of individuals of the same species, which are in reality only resting for a day or two in the course of their leisurely travel. For example, I should find it hard to say with any certainty at what time the Whinchats leave my own neighbourhood, though the bird is very abundant and obvious here all through the summer. I can state without hesitation that they were with us till the end of August; on the 26th of that month they were in large numbers about their favourite nesting-places on the railway banks. I was away the greater part of September, and to-day (1st October) I am unable to find a single Whinchat. But I should not be surprised if I were to see one or two more; they have occasionally been here as late as this. Should they appear again I shall conclude that these are travel- 
lers from the north and west, and that our own birds made their start during my absence in September.

Something may be done by keeping a daily list of all birds seen during August and September; in this way not only will the last appearance of some residents be detected, but a few casual travellers may fall into the net. Something too may be done by following the migrants on their journey, making up the list of all birds seen, as at home. Unfortunately it is not possible to be at home and to travel at the same time; and ornithologists are usually attracted in the autumn by the vast immigration of birds into this country from the east and north, and find much more interesting occupation on our eastern coast than on the western or southern districts. This year I stayed at home till 4th September, keeping a list in conjunction with two nephews, boys who were being initiated into the mysteries of ornithology as an agreeable holiday task. From the 12th to the 26th of September I travelled with one of them in the south of England, beginning in Cornwall and finishing in Kent. In neither period were the results at all striking, nor indeed did I expect that they would be ; but, taken in conjunction with the observations of other years, they may be worth setting down as an epilogue to these summer studies.

During the whole of the three weeks in August which we spent here at Kingham, we were continu- 
ally walking or driving about the country, and I doubt if we could well have missed any birds which were about; I was aided by two pairs of sharp young eyes and ears, and was called upon to look at and identify almost every bird that showed himself. Yet it is a singular fact that until the very last day we failed to bring the Skylark into our list. It could hardly have been the case that the Larks were all skulking in the standing corn, for it was being cut all round us in the latter half of August. There were plenty of Skylarks breeding here in the summer, and there are plenty here now-the first day of October. If their absence in August is to be explained on the ground that they were hiding during the moult, it is at least odd that not a single one should have met our eyes during three weeks. I am almost tempted to guess that our own Larks had left the neighbourhood, possibly to migrate by the south coast to the continent, and that the birds we have with us now (1st October) are arrivals from the east and north. But such a conjecture can have no value unless it be supported by a long series of observations; and much may doubtless be urged against it.

Another familiar bird was also wholly missingthe Corn Bunting. Ours is a district in which this bird delights, and I was under the impression that I could produce one for inspection at any time of year. 
264 Summer Studies of Birds and Books cHap.

But whether they were skulking and moulting,-in an even more melancholy state of mind than usual, -or whether they had really left us, it is certain that they were not to be found. The Corn Bunting is not celebrated as a migrant; but it is well known to ornithologists that its numbers are largely increased in the autumn by arrivals from the north of Europe, and it is possible that in this case too our resident birds had already left us to make room for the new-comers. ${ }^{1}$

These were our most notable absentees. All our regular summer visitors were with us, though perhaps in diminishing numbers, except the Cuckoo, the Nightingale (which disappears mysteriously, I know not when), and the Swifts and Shrikes, the last birds to arrive in May. These last left us while we were forming our list. On 16th August it was pretty plain that the Swifts were going and that the summer was drawing to an end. We saw one or two on the 18th and 19th, and on the 27th a small party passed on migration. This was the last we saw of them. In 1891, the year in which the whole tribe of Swallows and Martins was so late in leaving us, the last Swifts were seen here on the fourth of September; and I have seen them even later on the coast of Dorset. The Red-backed Shrikes had left their nesting-places at the end of July, and

${ }^{1}$ See Newton's edition of Yarrell, vol. ii. p. 40. 
I did not see another till 26th August, when a young bird, which most probably had missed his way on his travels, appeared on the telegraph wires, and was gone the next day.

Other stray travellers began to show themselves as August crept on, and made up for the comparative dulness of that month for the ornithologist. Not indeed that most beautiful bird the Green Sandpiper, which for years used to enliven our Augusts; he has deserted us for some inscrutable reason, and left his favourite stream to the Kingfishers, which are now again growing more abundant every year. But a fine show of orange-red berries of the mountain-ashes in my garden brought a new and strange visitor, for whose sake, would he but have stayed, I would willingly have sacrificed them. The thrush tribe are so passionately fond of these berries that I enjoy the sight of them for only a very few days; and this year a young Ring-ousel, the only one I have ever seen in the neighbourhood, having no doubt lost his way on migration, found these out and hankered after them for a whole day. He startled me by his unmistakable alarm-note early in the morning of 16th August, and again and again that day he tried to get at the berries, flying round and round while we were playing on the lawn, and in spite of his natural wildness alighting now and then on the tree, but always on the side of it away from us. But even such hard- 
won luxuries could not detain him long; he was gone next morning.

We cannot be in the line of the Ring-ousel's travel, for the only other occurrence of which I have a record is that of a wanderer who was killed against the telegraph wires many years ago. I rather think that in coming from the north they prefer the high ground, and take the line of the Cotswolds, where I found them on 1st September of last year, and so pass over the Wiltshire downs to the south coast; while the Welsh birds collect in suitable cover on the south coast of Wales, where I have often seen them in autumn, and cross to Exmoor over the Bristol Channel. But the Wheatears, which rarely or never breed about here, regularly take us in their autumn migration, and in much larger numbers than we see in the spring. This year the first appeared on 24 th August, dotted about in certain favourite fields; and then for several days they were to be found together with the Whinchats on the railway banks and telegraph wires. All, so far as I could discover, were smallish birds, of that less handsome race which visits us in spring somewhat earlier than the larger one. ${ }^{1}$

Meanwhile the Swallows and Martins had begun to collect on sunny mornings on the roof of my house,

1 Some birds which occasionally appear here in spring seem never to return our way in autumn: e.g. the Pied Flycatcher and the Common Sandpiper. 
and a vast gathering of them in a neighbouring village warned us that migration was at hand. On 14th September I left for Falmouth, hoping to see something of what these birds were doing in the far west, and to follow them eastwards if they had begun to move. But here the weather, which had been very cold and rainy, suddenly changed, and we came again into a summer which was tempting the birds to linger. The morning after our arrival we crossed the harbour in a boat to a beautiful sunny promontory, with wood and gorse coming down to the water; it was positively hot, and birds and butterflies were abundant. In the gorse at one warm spot my nephew caught a sound which I should have missed if I had been alone ; he wished to know what it was, and, pushing a little way into the gorse, I heard to my astonishment the reel of the Grasshopper Warbler. It was new to me that this bird ever finds his voice again in the autumn. But Macgillivray, in a passage often quoted, implies that he used to hear it at Norwich as late or later than this, and Mr. Mansell Pleydell once heard it in Dorset in September.

In a day or two the fine weather showed signs of breaking up, and the birds began to move a little. Along the beach the Pied Wagtails were dallying, yet clearly moving eastwards, and among them were one or two unmistakable White Wagtails - birds which we do not often see in Oxfordshire. One of 
268 Summer Studies of Birds and Books cHap.

these was a very conspicuous adult bird, with the black crescent in front remarkably bright and the upper parts a uniform light gray-so light in fact that the bird seemed almost white as he flitted past me. A journey to St. Ives, on the western coast, showed us a very large collection of Wagtails on the fields above the beach, and among these too there seemed to be one or two of the rarer species. The Pied Wagtail, the Meadow Pipit, and the Linnetof which last there were in some places immense numbers-were the three species which obliged us with their companionship during the whole of our travel along the south coast.

It was only on the last day of our stay at Falmouth that the Swallows and Martins began to show distinct signs of migration. That day they were passing in small parties over the promontory where we had found the Grasshopper Warbler, all going pretty steadily eastwards. Next day, the 19th, I saw from the train window just east of Exeter a vast congregation of them, extending at least two or three miles. This leads me to suspect that the birds which pass along the north coast of Somerset and Devon, coming from Wales and the Severn valley, cross the latter county to the south by way of Barnstaple and the river Taw, and then, instead of striking the sea at Exmouth, follow an inland route eastwards, past Honiton and Axminster, until they reach the 
Dorset coast. By the sea at Sidmouth, where we spent one whole day, we saw nothing of them; that loveliest of watering-places had nothing to show us in the way of migration. No bird, indeed, need have wished to leave such a tropical climate as we found there; the Chiffchaff was in full and vigorous song there on the 20th, and the Willow-wren was also heard.

On the 21st we went on to Swanage in cooler weather, with rain falling at intervals. Swanage is a good point for watching the movements of such birds as pass along our southern coast; for here ends abruptly that long line of down which includes Bindon Hill, and here too ends the long stretch of coast extending eastwards from Weymouth Bay. Birds which are pursuing either down or coast-line will, when they arrive at Swanage, have to consider what to do next : whether to turn up northwards to Poole harbour and Bournemouth, or to go straight across to the Isle of Wight, which on any clear day is distinctly visible. The result seems to be that the angle formed by Swanage Bay and the coast from St. Aldhelm's Head to Durlstone Point is sometimes as full as it can hold. of birds in the autumn, and chiefly of Linnets, Pipits, and Wagtails, with a fair sprinkling of Warblers and Chats; and here too the Landrails seem to congregate, for no less than twenty-five were shot here in a single field by a sporting friend of mine. 
But the travelling of Swallows and Martins is what chiefly attracts me to this region. On 20th September 1887, while staying at Lulworth, halfway between Weymouth and Swanage, I discovered that every Swallow and Martin which I saw was steadily travelling eastwards. They travelled in parties of from fifty to two hundred, just as I had seen them in the Alps, and as they are described in the "Migration Reports." I could trace these parties for a long distance with my glass, as I stood on a long and narrow ridge of down some five hundred feet above the sea; their general direction was always due east, though they seemed to follow pretty closely the long line of the down, which curves somewhat inland eastwards from Lulworth. The whole day they continued to pass, not in a continuous stream, but in these great packs, which at one moment were over my head and all around me, and in two or three minutes had quietly slipped on full half a mile towards the east. They did not, of course, fly straight ahead in a direct route; they seemed to be ever dallying and circling round, or sweeping backwards; yet you only had to keep a vigilant eye on them to discover that they were all the time moving onwards, and travelling at a rate which I guessed to be not much less than ten miles an hour.

On that day the wind was easterly, and therefore dead against them; but it was a gentle breeze, and 
they were able to fly without apparent effort at a considerable height. The next day the wind was stronger; and on the third day, if I recollect right, it was very keen and cold, and instead of soaring they changed their tactics and took to skimming low along the steep flanks of the down. From my post of vantage at the top I watched with interest the way in which these delicate little birds withstood and conquered the force of a strong head wind. I can see them even now creeping along the shaggy sunburnt sides of that noble breezy down, tacking this way and that, now deep in the grassy hollows, now steering swiftly upwards, now yielding to the gale for a moment in a backward curve, but ever steadily pressing onwards. Some preferred a belt of lower ground between the down and the sea; but I noticed that where this comes to an end and the down itself falls again in precipitous cliffs direct into the waves, they all turned inwards again, hugging the hill, and not venturing to cross even a mile or two of sea to the further arm of the bay in the face of such a wind.

All this was so interesting that I wondered that I had never observed the same thing during previous visits to Lulworth in September. Diaries kept during those visits were at hand, but showed no trace of any such migration. Possibly I had missed the exact days on which the birds were passing; but it is 
more likely, I think, that I simply failed to notice what was going on. The flight of these birds is so deviating that its general direction may very easily be missed, and in fact it is almost indispensable that the observer should be posted on some commanding height in order to appreciate it. I have seen the same kind of migration going on in the Midlands since that visit to Lulworth, but found it very difficult to follow and make sure of, owing to the want of such a point of vantage as that noble ridge of down.

On returning that autumn to my Oxfordshire home, I found that considerable parties of Swallows and Martins were passing over the village at intervals every forenoon. Our own birds, which regularly gather on my house roof for a week or two before they leave, had apparently departed; but from north and west fresh companies continued to arrive, and it was long before we felt that "the Swallows had really gone." These strangers lingered a while about the village, generally in the neighbourhood of the church, and then took their departure in a south-easterly direction along the line of our valley. But, as I have already said, it was difficult to trace their line of flight, and impossible to follow it for any distance, owing to the want of a commanding hill whence I could sweep the whole country with my glass. I may mention that one day at nightfall I found a 
small orchard in a neighbouring village crowded with them; and no doubt this was a detachment resting for the night, which would proceed on its way early next morning.

The following year, 1889, I discovered that Swanage is an even better place than Lulworth for "taking the auspices" in the autumn. On the 6th of October, just before the Oxford term began, I was able to pay a hurried visit to Swanage to see an old pupil, whose family understand and indulge my proclivities with most hospitable kindness. When on the morning of the following day I reached the coast near Durlstone Point, I found the Swallow migration still going on, for a small party soon passed me and disappeared in an easterly direction. As they vanished the question occurred to meWhat will they do when they reach the point where the coast turns northward at a sharp right angle? Will they follow it, or will they cross the sea to the Isle of Wight, or is this perhaps a point at which they boldly strike across to France? It began to dawn upon me, in fact, that this sudden turn in the line of the coast would surely raise a question in the minds of the birds as well as in mine, and I was extremely curious to see what they would do.

The question was soon answered. Walking nearer to Durlstone Point, I watched for another party, which was not long in coming. They passed by me; 


\section{Summer Studies of Birds and Books char.}

and, as they neared the headland, rose in the air higher and higher, not seeming to move onwards for a while, but simply circling round and rising, and then, at a great height, they set off over the sea in the direction of the Isle of Wight. I followed them with the glass till they were such tiny specks that it was painful to try and keep them in view. The cliffs of the island were at this time very distinctly visible. I watched one or two more parties follow in the same track; but I was not alone and could not stay long - my kind host was with me, and friendship forbade that I should weary him. It was not until the morning of the 9th that I was at liberty to spend an hour or two in the same spot in solitude.

As I left the house that morning the hills were hidden in a soft mist, nor could I see anything of the Isle of Wight; and it did not occur to me at the moment that this might have some effect on the course adopted by the birds. I was consequently rather taken by surprise, when I reached the cliffs about a mile west of Durlstone and watched the first party that passed me, to find that, instead of rising in the air and going out to sea, they turned back when they came near the headland, and still skimming close to the ground, and passing close to me as I sat sheltered from the wind under a wall, they made northwards over the hill towards the town of Swanage. After waiting a while, I saw another party take exactly the 
same course. They refused the sea-passage, and turned inland and northwards. The nature of the ground I was on prevented my watching them in this direction to any distance; and I could only stand there and wish that some kind wizard would turn me into a Swallow for but one hour, that I might follow in their track, and learn something of the ways and the minds of these little travellers. But it was a fair guess that, having refused the sea once, they would hug the land for some distance at least.

The sun had now come out, and I sat down to enjoy it while waiting for a third company of Swallows. All the birds I saw that morning, I may say, were Swallows, not Martins; and all of which I had a good view were young birds, so far as I could judge by their tails. Presently another series of ghostly little forms came gliding over me, and $I$ at once jumped up and kept the binocular steadily on them as they went eastwards. But this company did not return inland as the others had done; like the party I had watched two days before, they rose in the air when they neared the point, and circling higher and ever higher, as if observing and considering, they at length began to disappear over the sea. I scrambled over a high loose stone wall, at the risk of breaking my bones, in order to reach a higher point and keep them longer in sight; and then 
it was that I discovered that the Isle of Wight had arisen out of the mist since I last was within view of it.

Though I have been at Swanage several times since 1889, I have never again caught the migration in full swing, or seen a party of birds cross to the Isle of Wight; the weather has been cold and rainy, and such parties as I have seen have always kept to the coast. This was the case in the present year, 1894, when the Swallows seemed all to be harking back from Durlstone Point, though the island was generally visible. The promontory was full of birds, and on all the broken ground occupied by deserted Purbeck quarries the Pipits and Linnets were in extraordinary numbers. The Wagtails of course were here; and at Studland Bay, three miles to the north, I was delighted to find all three species together, the Pied, the Yellow, and the Gray, in a little flock which seemed to be working slowly along the shore.

On leaving Swanage we had yet one day of my nephews' holidays, and it chanced that we spent it at Bexhill, two or three miles west of Hastings. At this point many birds might have already crossed the Channel ; but even here there was much travelling to the eastwards. Parties of Hirundines-nearly all of them Swallows, though I saw a single Sand-martin -were hurrying towards Hastings; the weather was heavy after a stormy night, and in a long stretch of wild ground to the west of the town the birds were 
threading the paths among the gorse, and would suddenly appear round a corner within a few feet of me, and fly almost between my legs. This reach of coast, which luckily has not been consecrated as yet to the overweening devotee of golf, affords excellent shelter to migrating birds, and would probably be a good station for an observer both in spring and autumn. Wagtails, Linnets, Pipits, Stonechats, and Wheatears were here that day (24th September); and a few Skylarks, who were probably going westwards.

Throughout our ten days travel we had seen nothing very startling in the movements of birds, nor any rare species. But a student of birds can find plenty to employ him in the haunts even of our most familiar companions. The one remarkable fact which met us at every place where we stayed-the fact which would probably have impressed itself most deeply on the mind of a foreign ornithologistwas the crowding and singing of Robins. Abundant as they are in autumn over the whole country, in the extreme south they seem to be closely packed in every garden, orchard, and hedgerow. And in spite of this abundance, which brought the song to my ears every hour and almost every minute I was out of doors, I found it impossible to weary of the strain; never has it seemed to me more rich and tender in tone, or more varied in execution and meaning. 
I was unable to follow the birds farther, as I had intended, or to cross to the coast of France at the time they too might be crossing. Returning to the Midlands, I found Swallows, Martins, and Pied Wagtails still here in large numbers; the Wagtails gathering in one field by the church, which they always frequent at this time, and the Swallows and Martins still crowding every sunny morning on my house roof. But it is quite plain that they are preparing to leave me; their flights seem to grow longer and longer, and if I did not follow them carefully with the glass I might fancy that they had utterly vanished. But however far they fly, and however high,- and at this time they will sometimes soar to a very great height,-I shall presently see them returning, and to-morrow morning the little black figures will be flitting before my bedroom window soon after the sun is up. The weather is calm, heavy, and not inclement, and the air is full of flies; and as long as there is neither hard frost, nor storm, nor a famine of insect food, we may expect to see these lingering reminiscences of the summer. ${ }^{1}$

Yet I doubt whether we shall have them with us

1 On 21st October, though nothing had been seen of them for several days, I was astonished on waking to see them once more, and in considerable numbers. They were all Martins; and they vanished to a bird while I was dressing. The thermometer at the time was under $40^{\circ}$. They were clearly a party of passing travellers. 
as late as in 1891, when I caught my last glimpse of a Swaliow in Oxford on the morning of 23rd November. There will be more than four months this winter between the departure of the last Swallow and the appearance of the first Chiffchaff. As I write this last paragraph (5th October), the wind has turned to the east, and brought cold rain with it. A large Gull, in immature plumage, has passed over the village in a north-easterly direction. Not a Warbler is to be seen anywhere; the Fieldfares and Redwings may be expected daily. We are getting ready for winter, and my summer studies are over. 



\section{APPENDIX}

\section{ON THE VOCAL ORGAN OF SINGING BIRDS}

My friend Mr. W. P. Pycraft, of the Oxford Museum, has been kind enough to provide me with the drawings reproduced on the accompanying plate, to illustrate the nature of the vocal apparatus as briefly explained on $p$. 125 foll. They are not intended to represent the complete result of Mr. Pycraft's researches, which are now in progress, but are only meant to give the reader some idea of (1) how the musical sound is generated, (2) how it is modified in pitch at the will of the bird. I have myself had the advantage of examining some of Mr. Pycraft's dissections ; and in order to make more sure of my ground on the musical side of the question, I called in the aid of Mr. F. Cunningham Woods, Mus. Bac. of Exeter College, who made some valuable suggestions, as will be seen below. The trachea and syrinx of birds have often been minutely examined by anatomists, and accounts will be found not only in the usual text-books, but in Macgillivray's British Birds (Introduction to vol. ii.), in Dr. Coues' Field and General Ornithology, and in Mr. Shufeldt's Myology of the Raven. These works, however, did not explain to me very clearly how the musical sound is originated. The help of Mr. Pycraft and Mr. Woods has cleared up some difficulties that presented themselves; but I confess that I am still un- 
certain about some points in the nature and working of the instrument.

Figures 1 and 2 show the way in which the sound is generated in the syrinx, or lower larynx, of the bird. The air from the lungs is blown into the windpipe through two bronchial tubes, which are seen in Fig. 1, looking something like the two legs of a pair of riding breeches. At the point of junction of these two bronchi, and stretching right across the fork, is a small bony bar; and supported on this bar is a membrane, rising into the trachea and called from its shape the semilunar membrane, which appears to vibrate like the free reed of an organ-pipe as the wind reaches it from the two bronchi. The currents of air from the two tubes catch this membrane on each side of it, and thus keep it, if the bird exerts force in expelling the wind, in a state of strong tension and vibration. In Fig. 1 this membrane, or reed as I may be allowed to call it, has been exposed to view by cutting away the outer side of the left bronchus and the part of the trachea immediately above it. It seems to be generally agreed that this reed is the essential sound-generator in the instrument.

But the extraordinary resonance of the voices of most birds can hardly be accounted for by the vibration of this membrane alone; and there seem to be two provisions for securing this resonance.

1. The cavity in which the "reed" is situated is not surrounded, like the upper part of the trachea, by complete bony rings, over which an elastic membrane is stretched; but the two bronchi, as they approach each other, are composed of bony half-rings on the outer side, while their inner sides, i.e. those next to each other, consist of free elastic (or tympanic) membranes unsupported by any stiff material and therefore capable of being stretched tight by the wind blown from the 



\section{EXPLANATION OF THE PLATE}

The figures represent dissections of the syrinx or organ of voice of the Hooded Crow, Corvus cornix, L., drawn from nature and slightly diagrammatic.

Fig. 1. - The lower end of the trachea and upper end of the left bronchus viewed from the side : a portion of the outer wall of the syrinx and bronchus has been removed, so as to expose the Membrana semilunaris (M.s.) and the Membrana tympaniformis interna (M.t.i.).

M.s. Membrana semilunaris.

M.t.i. , tympaniformis interna.

R. Right bronchus.

L. Left bronchus.

E. Tracheal rings extended.

C. , , , contracted.

Fig. 2.-A portion of the outer wall of Fig. 1, seen from the inside, and showing the fleshy fold $\mathrm{F}$.

Fig. 3. -The lower end of the trachea and upper end of the left bronchus viewed from the side, showing the origin and insertion of the principal muscles.

Br. II. Bronchial ring II.

Br. III. , , , III.

M.t.e. Membrana tympana externa.

S.t. Sterno-trachealis muscle.

T.b.v. T'racheo-bronchialis ventralis muscle.

T.b.d.l. , , , dorsalis longus muscle.

T.b.o. ", ", obliquus muscle.

S.d. Syringeus dorsalis muscle.

S.v. $\quad, \quad$ ventrilateralis muscle. 

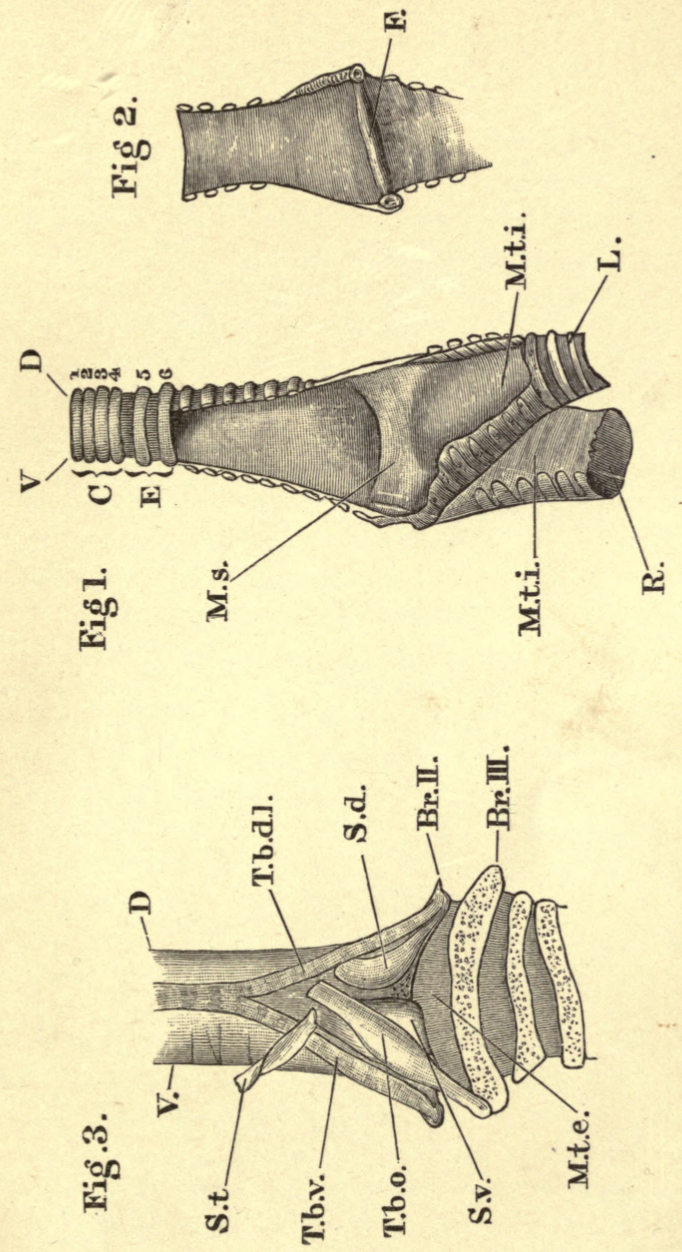

lungs. Thus the whole cavity acts as a sound-chamber, and is subject to tension and vibration together with the "reed."

2. Exactly opposite to the bony bar on each outer side of this sound-chamber, and supported by one of the half-rings just mentioned, there seems to be what Mr. Pycraft describes as a fleshy fold. I use the singular number, because in freshly-killed specimens Mr. Pycraft has only been able hitherto to find one, though in some books it is represented as double. These folds can hardly be, as some seem to have thought, the equivalent of the vocal cords in the human being; they do not seem to be sufficiently membraneous or important to generate musical sound independently. What then is the function they perform? In order to try and answer this question I called Mr. Woods into consultation. He suggested that their use might be either to vibrate in sympathy with the "reed," like the sympathetic strings of the old viola d'amore, or to help in increasing the tension of the sound-chamber, or to direct the wind upon the reed by narrowing the two passages of the bronchi immediately below it. In order to determine if possible which of the three guesses was the most probable explanation, Mr. Woods and I paid a visit to the Museum and examined a trachea and syrinx which Mr. Pycraft had ready for us. They happened to be those of a jay, - of all birds the most unmusical; but if the apparatus of this bird is in the main like that of most others, the fleshy folds are placed just below the "reed" (opposite to the bony bar on which the reed rests), a position which would certainly suggest our third explanation. On that hypothesis the folds would act as a kind of lips, compressing the currents of wind in the two bronchi, and directing them with greater force and effect upon the vibrating membrane which I have called a reed. 
We may suppose then,- - though I do not speak with any certainty on so difficult a question, - that the bird's instrument consists primarily of a vibrating reed, placed in a sound-chamber which is itself capable of vibration, and which is provided with an apparatus for increasing or decreasing the force of the wind brought to bear upon the reed.

Fig. 3 needs no elaborate explanation. It is meant to illustrate the muscular apparatus which is attached both to the sound-chamber (syrinx) and to the windpipe (trachea), and which enables the bird to produce a great variety of notes by stretching and relaxing these, as I have explained on p. 127. The reader who is curious enough to examine these carefully, with the aid of Mr. Pycraft's explanations and of the books I have mentioned above, will not fail to understand that they play the part of the fingers of a performer on a windinstrument, by increasing and lessening the length of the pipe through which the musical sound is forced after being generated as described above. At the top of Fig. 1 Mr. Pycraft has diagrammatically illustrated the way in which this is effected by drawing four tracheal rings in a state of relaxation and resting on each other, while below are two others separated by the tension of the elastic membrane covering them, which tension is the result of the action of the muscles shown in Fig. 3.

It does not seem probable that the upper larynx, at the end of the windpipe next to the mouth and bill, has any effect on the musical sound, "otherwise than by dividing or articulating the notes after they have been formed in the lower larynx" (Sir R. Owen, quoted by Mr. Shufeldt in Myology of the Raven, pp. 44-47).

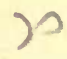

Printed by R. \& R. CLARK, Edinburgh. 

UNIVERSITY OF CALIFORNIA LIBRARY BERKELEY

THIS BOOK IS DUE ON THE LAST DATE STAMPED BELOW

Books not returned on time are subject to a fine of $50 \mathrm{c}$ per volume after the third day overdue, increasing to $\$ 1.00$ per volume after the sixth day. Books not in demand may be renewed if application is made before expiration of loan period.

\section{DEC 21. 1018}

\section{APR 851924}




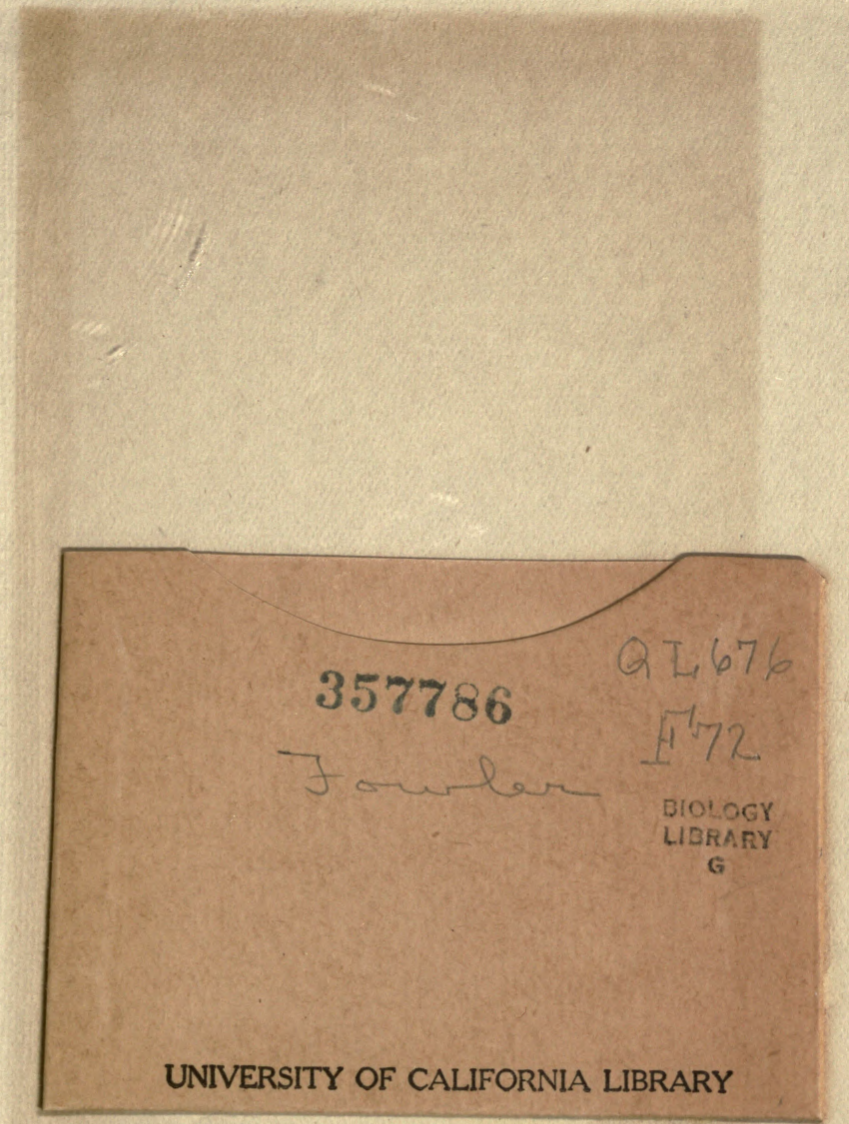


